\title{
Chronic Lymphocytic Leukemia
}

\author{
Nicholas Chiorazzi, ${ }^{1}$ Shih-Shih Chen, ${ }^{1}$ and Kanti R. Rai ${ }^{2}$ \\ ${ }^{1}$ The Feinstein Institutes for Medical Research, Northwell Health, Manhasset, New York 11030, USA \\ ${ }^{2}$ The Donald and Barbara Zucker School of Medicine at Hofstra/Northwell, Hempstead, New York 11549, USA \\ Correspondence: NChizzi@ Northwell.edu
}

Patients with chronic lymphocytic leukemia can be divided into three categories: those who are minimally affected by the problem, often never requiring therapy; those that initially follow an indolent course but subsequently progress and require therapy; and those that from the point of diagnosis exhibit an aggressive disease necessitating treatment. Likewise, such patients pass through three phases: development of the disease, diagnosis, and need for therapy. Finally, the leukemic clones of all patients appear to require continuous input from the exterior, most often through membrane receptors, to allow them to survive and grow. This review is presented according to the temporal course that the disease follows, focusing on those external influences from the tissue microenvironment (TME) that support the time lines as well as those internal influences that are inherited or develop as genetic and epigenetic changes occurring over the time line. Regarding the former, special emphasis is placed on the input provided via the B-cell receptor for antigen and the C-X-C-motif chemokine receptor-4 and the therapeutic agents that block these inputs. Regarding the latter, prominence is laid upon inherited susceptibility genes and the genetic and epigenetic abnormalities that lead to the developmental and progression of the disease.

$\mathrm{C}$ hronic lymphocytic leukemia (CLL) is a disease of aging adults. Because it often begins as a relatively indolent condition with many patients having long survival, CLL has a high prevalence rate, making it the most common adult leukemia in western countries. The disease results from the overgrowth of a single $\mathrm{CD}^{+}$ B lymphocyte co-expressing low levels of surface membrane immunoglobulin (smIg) of a single IG light (L) chain type and of CD79b, CD20, and CD23. The clinical consequences of this clonal overgrowth are highly variable: Some patients die within $2-3$ yr of diagnosis, whereas others survive decades beyond. This variability is due to factors intrinsic to the leukemic B cell (e.g., genetic and epigenetic changes in coding and noncoding genes) and factors extrinsic to the leukemic cell (e.g., inputs delivered by various signaling pathways in the tissue microenvironment [TME]).

This perspective is organized according to the order CLL evolves in patients. It starts with epidemiologic, genetic, and environmental factors that influence development of the disease, follows with features leading to the clinical presentation, diagnosis, and initial treatment, if necessary, and concludes with elements causing disease progression or therapy refractoriness,

Editors: Michael G. Kharas, Ross L. Levine, and Ari M. Melnick

Additional Perspectives on Leukemia and Lymphoma: Molecular and Therapeutic Insights available at

www.perspectivesinmedicine.org

Copyright (C) 2021 Cold Spring Harbor Laboratory Press; all rights reserved; doi: 10.1101/cshperspect.a035220

Cite this article as Cold Spring Harb Perspect Med 2021;11:a035220 
N. Chiorazzi et al.

describing current and emerging therapeutic options. Emphasis is placed on recent findings relating to these three periods.

\section{DISEASE DEVELOPMENT}

\section{Epidemiology}

According to the National Cancer Institute's Surveillance, Epidemiology, and End Results Program (SEER), the estimated number of new cases of CLL in the United States in 2018 was 20,940, representing $\sim 1.2 \%$ of new cancer diagnoses and the number of deaths from CLL was $4510, \sim 0.7 \%$ of all cancer deaths (SEER Cancer Stat Facts: Chronic Lymphocytic Leukemia, National Cancer Institute, Bethesda, MD; https://seer.cancer .gov/statfacts/html/clyl.html). Median age at diagnosis was 70 , with the highest numbers of cases identified in the 65-74 yr age group.

However, these statistics are not relevant worldwide as the incidence of CLL varies based on race/ethnicity: White $>$ Black $>$ Hispanic $>$ Asian/ Pacific Islander. Incidence also varies based on gender, being approximately two-fold more frequent in males.

\section{Environmental Considerations}

Exposure to pesticides, specifically deltamethrin (Leon et al. 2019), and herbicides (Alavanja et al. 2014; Coggon et al. 2015) has been associated with the development of CLL; the most convincing is Agent Orange used during the Vietnam War (Baumann Kreuziger et al. 2014; Mescher et al. 2018). Radon exposure has shown a similar relationship (Schwartz and Klug 2016).

The link with ionizing radiation is controversial. Because CLL incidence did not increase among Japanese exposed to atomic bomb blasts in World War II (Preston et al. 1994), ionizing radiation was not considered a risk factor. However, epidemiologic studies of people in the vicinity of the Grenoble nuclear power plant breakdown suggest an increased incidence among exposed individuals (Gluzman et al. 2006; Chumak et al. 2008; Kesminiene et al. 2008; Romanenko et al. 2008; Zablotska et al. 2013), so this conclusion needs reconsideration.
Finally, respiratory tract infections, cellulitis, and herpes zoster can presage CLL (Landgren et al. 2007a,b; Lesley et al. 2009), implying an underlying immune defect predisposing to disease development. Consistent with this, hypogammaglobulinemia is common in CLL and can precede diagnosis (Lenders et al. 1984; Tsai et al. 2009).

\section{Genetic Considerations}

\section{Inheritance of Susceptibility Genes}

CLL has the highest incidence of familial association among leukemias, with first-degree relatives having more than eight-fold higher likelihood of developing the disease (Goldin et al. 2004). Conversely, the low CLL incidence among Asians/Pacific Islanders, particularly Japanese, does not increase when living in the United States (Gale et al. 2000). Both observations strongly imply involvement of inheritable susceptibility alleles that promote or prevent disease. Genome-wide association studies (GWASs) identified several polymorphic genetic loci ( $\mathrm{Di}$ Bernardo et al. 2008; Crowther-Swanepoel et al. 2010a; Slager et al. 2011, 2012; Berndt et al. 2013, 2016; Speedy et al. 2014). These have been refined to the nine most likely (Law et al.2017), which are transcriptionally active in CLL cells and contain genes involved in the control of human B-cell development and signaling or of immune function (Law et al. 2017). Consistent with this, GWASs of CLL and myeloma patients uncovered shared risk loci influenced by polymorphisms in B-cell regulatory elements affecting genes involved in B-cell development (Went et al. 2019).

Normal B-lymphocyte development proceeds by an ordered process of cellular maturation occurring in the bone marrow (BM), beginning with a hematopoietic stem cell (HSC) and culminating with a mature B cell (Fig. 1A). Mature B lymphocytes evolve to memory and/or plasma cells based on the types of antigens encountered in the periphery and the maturation pathways they are guided to follow by cells of the hematopoietic and nonhematopoietic lineages. Thus, susceptibility genes can exert in- 

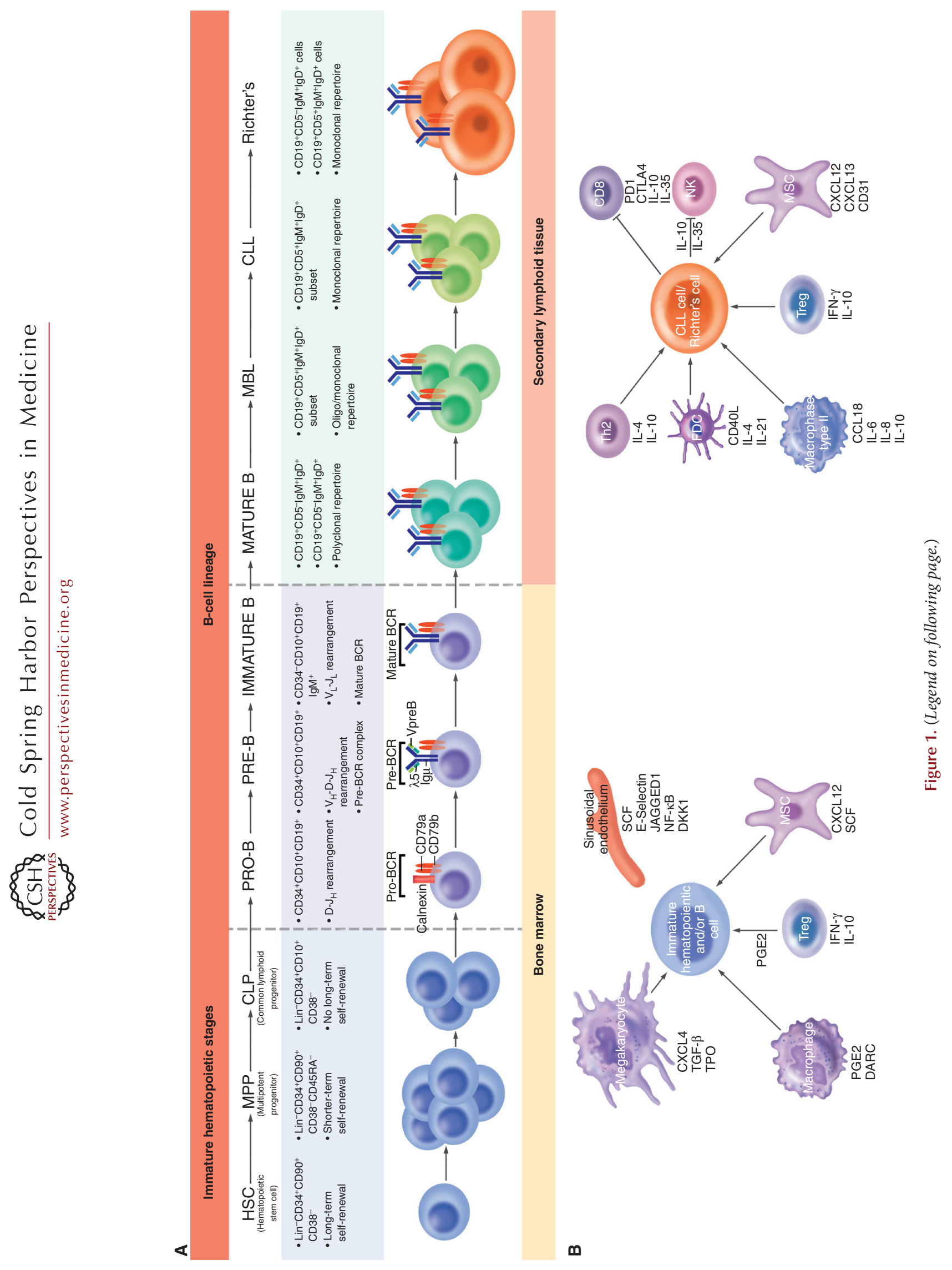
N. Chiorazzi et al.

fluences at many points along the B-cell differentiation path.

\section{Noninherited Recurrent Genetic Mutations in CLL Cells}

The leukemic cells from the majority of patients exhibit chromosomal abnormalities at some point in the course of disease. Moreover, normal cells at early stages of hematopoiesis taken from CLL patients have mutations present in their leukemic clone (Damm et al. 2014; Marsilio et al. 2018). Transplantation of HSCs from CLL patients into immune-compromised mice leads to mature $\mathrm{CD}^{+} \mathrm{B}$ cells resembling those in CLL patients (Kikushige et al. 2011). These early mutations, however, are not sufficient to yield the full-fledged disease (Kikushige et al. 2011) but result in a pre-leukemic state resembling monoclonal B lymphocytosis (Rawstron et al. 2002b).

The most common somatic abnormalities found in mature CLL cells are del13q, tri12, del11q, and del17p, in this order of frequency
(Döhner et al. 2000; Haferlach et al. 2007; Zenz et al. 2010a; Stilgenbauer 2014). Deletions at 13q and tri12 are found at diagnosis, suggesting these are initiating events; del11q and del17p are most often found later in disease, implying they promote clonal evolution and disease progression. The incriminating genetic elements in del13q are two microRNAs, $m i R 15 a / 16 b$ (Calin et al. 2002). Loss of $m i R 15 a / 16 b$ leads to overproduction of the anti-apoptotic protein $\mathrm{Bcl}-2$ (Cimmino et al. 2005) and heightened cell-cycle progression (Klein et al. 2010), both oncogenelike effects. Moreover, mice with a defective miR15/16 spontaneously develop a CLL-like disease (Raveche et al. 2007; Hayakawa et al. 2016), and deletion of the chromosomal region corresponding to $13 \mathrm{q}$ in mice leads to murine CLL (Klein et al. 2010; Kasar et al. 2016).

The advent of high-throughput, next-generation deep DNA sequencing enabled the demonstration that CLL cells also exhibit specific gene aberrations. Beginning in 2011 (Fabbri et al. 2011; Puente et al. 2011; Quesada et al.

Figure 1. (Continued.) Microenvironment-supported B-lymphocyte development in patients with chronic lymphocytic leukemia (CLL). (A) Differentiation scheme assumed for CLL and Richter's transformation (RT) cells. Normal B lymphocytes progress through an ordered differentiation program that begins with hematopoietic stem cells (HSCs), proceeds through multipotent progenitor cells (MPPs), and then common lymphoid precursors (CLPs). After this point, commitment is made to the B-lymphocyte lineage. Pro-, pre-, and immature B cells differ based on the progressive rearrangements of $I G H V, I G H D$, and $I G H J$ genes. IGHD-IGHJ rearrangement is completed in pro-B cells, followed by $I G H V-I G H D-I G H J$ rearrangement in pre-B cells, and both IGHV-IGHD-IGHJ+ IGLV-IGLJ rearrangements in immature B cells. Thus, antibodies that can create a complete B-cell receptor (BCR) exist from the pre-B cell-immature B cell interphase and at later stages of B-cell development (transitional, mature, etc.). Mutations in CLL HSCs and MPPs have been documented (Damm et al. 2014; Marsilio et al. 2018), and xenografting CLL HSCs/MPPs into severely immune-compromised mice (Kikushige et al. 2011) leads to a condition resembling monoclonal B-lymphocytosis (Rawstron et al. 2002a). If leukemia stem cells exist in CLL, HSCs, MPPs, CLPs, and pro-B cells carrying genetic abnormalities would be considered "pre-leukemic stem cells" and not "leukemic stem cells," because they could not give rise to a CLL cell with the same IGHV-IGHD-IGHJ+ $I G L V$-IGLJ rearrangements. The latter is relevant because, upon disease relapse, the emerging cells express a complete B-cell receptor ( $I G H V$-IGHD-IGHJ $+I G L V-I G L J$ rearrangements) that indicates it is a member of the original CLL clone. Hence, we suggest the true leukemic stem cell in CLL resides at a differentiation stage at or beyond the pre-B cell-immature B cell interphase. CLL cells proliferate in secondary lymphoid organs and can transformation to Richter's cells, often as CLL-derived diffused large B-cell lymphoma (DLBCL) that have larger cells with prominent nuclei. (B) Microenvironmental signals associated with clonal expansion. (Left) Bone marrow microenvironment that supports normal and abnormal hematopoietic development. Bone marrow niche supports the differentiation and maturation of B cells. Immature HSCs and B cells are maintained and regulated by niche factors (i.e., CXCL12 and SCF produced by MSC), endothelial cell-derived signals (i.e., SCF, E-selectin, JAGGED1), and the progeny of HSCs including macrophages and megakaryocyte and regulatory T cells. (Right) The secondary lymphoid microenvironment sustains CLL and RT cells. CLL and RT cells receive growth promotion (e.g., IL-4, IL-21, CD40L, CCL19) and suppression (e.g., IL-10, IL-35, and PDL1-PD1 interaction) signals, as well as cell homing and retention cues (CXCL12, CXCL13, and CD31). Th2, T helper 2 cells; FDC, follicular dendritic cell; NK, natural-killer cell; MSC, mesenchymal stromal cell; Treg, T regulatory cell. 
2011; Wang et al. 2011) and now involving approximately 1000 CLL exomes (Quesada et al. 2012; Landau et al. 2013, 2015; Puente et al. 2015; Ljungström et al. 2016), a series of gene mutations was identified in CLL, although not as plentiful as in solid tumors (Table 1; Pleasance et al. 2010). Most of these lead to amino acid changes, suggesting selection for pathogenicity. Pathways controlling DNA damage repair/cell cycle control, Notch signaling, IL-1R family signaling, Wnt signaling, and RNA processing and export, MYC activity, and MAPK signaling are affected (Wang et al. 2011; Landau et al. 2015).

More disease-driving aberrations are found in $I G H V$-unmutated CLL (U-CLL) than in $I G H V$-mutated CLL (M-CLL). Additionally, certain mutations occur more frequently in $\mathrm{U}$ CLL (NOTCH1, XPO1, and POT1) and others in M-CLL (del(13q), MyD88, and CHD2), or in
CLL subsets with specific genomic aberrations (e.g., $M y D 88$ with del13q; SF3B1 with del11q; NOTCH1, BIRC3, FBXW7, and BCOR with tri12 [Table 1]). Moreover, sets of mutations associate with the use of certain stereotyped $I G H V$ $I G H D-I G H J$ gene rearrangements (Rossi et al. 2009b; Sutton et al. 2016). Selected mutations occur in specific regions of individual genes (e.g., PEST domain of NOTCH1 and HEAT domain of $S F 3 B 1$ ). In some instances, a relationship exists between a specific abnormality and aggressive clinical course and/or shortened survival (Rossi et al. 2012a); this might be caused by development of Richter's transformation (RT) (Richter 1928) (Table 2; Fabbri et al. 2011; Rossi et al. 2012b)

Collectively, these associations and the fact that no single mutation is found in every CLL clone strongly suggest the development of CLL differs for distinct subsets of patients. In this

Table 1. Recurrent mutations in chronic lymphocytic leukemia (CLL) B cells that associate with chromosomal aberrations, IGHV genes, and mutation status and stereotyped subsets

\begin{tabular}{|c|c|c|c|}
\hline Mutation & Chromosomal aberrations $^{\mathrm{a}}$ & IGHV gene ${ }^{b}$ & Stereotyped subset $^{\mathrm{c}}$ \\
\hline \multirow[t]{3}{*}{$S F 3 B 1$} & del11q & IGHV1-69 (unmutated) & $\# 3, \# 7$ \\
\hline & $\operatorname{del} 13 q$ & IGHV3-21 (unmutated) & $\# 2$ \\
\hline & & IGHV3-21 (mutated) & $\# 2$ \\
\hline \multirow[t]{2}{*}{ ATM } & del11q & IGHV3-21 (unmutated) & $\# 2$ \\
\hline & del13q & IGHV3-21 (mutated) & $\# 2$ \\
\hline \multirow[t]{3}{*}{ NOTCH1 } & Trisomy 12 & IGHV1-69 (unmutated) & \#6 \\
\hline & & IGHV4-39 (unmutated) & $\# 8$ \\
\hline & & Clan I genes (unmutated) & \#1, \#99, \#59, \\
\hline$B C O R$ & Trisomy 12 & & \\
\hline$B I R C 3$ & Trisomy 12 & & \\
\hline FBXW7 & Trisomy 12 & & \\
\hline \multirow[t]{2}{*}{ XPO1 } & del11q & U-CLL > M-CLL & \\
\hline & $\operatorname{del} 13 q$ & & \\
\hline \multirow[t]{2}{*}{ POT1 } & del11q & U-CLL > M-CLL & \\
\hline & del13q & & \\
\hline $\mathrm{CHD} 2$ & del13q & $\mathrm{M}-\mathrm{CLL}>\mathrm{U}-\mathrm{CLL}$ & \\
\hline \multirow[t]{2}{*}{ TP53 } & del13q & Clan I genes (unmutated) & \#1, \#99 \\
\hline & del17p & & \\
\hline MYD88 & del13q & M-CLL > U-CLL & \\
\hline SAMHD1 & del13q & & \\
\hline
\end{tabular}

${ }^{\mathrm{a}}$ Main recurrent genetic aberrations associated with chromosomal abnormalities of known prognostic significance in CLL.

${ }^{\mathrm{b}} I G H V$ (immunoglobulin heavy variable) gene and mutation status associated with common genetic aberrations. IGHV gene mutations are determined based on degree of identity with the germline ( $\geq 98 \%$ identity = "unmutated," U-CLL; $<98 \%$ germline identity = "mutated," M-CLL). Mutations of XPO1, POT1, CHD2, and MYD88 are not associated with a specific IGHV gene mutation but occur more frequently in M-CLL or U-CLL.

${ }^{\mathrm{c}}$ Stereotyped subset-biased acquisition of recurrent gene mutations. MYD88 and BIRC3 mutations are rare in all subsets. 
N. Chiorazzi et al.

Table 2. Biological pathways associated with common mutations

\begin{tabular}{ll}
\hline Type of pathway & \multicolumn{1}{c}{ Common mutations } \\
\hline RNA and ribosomal-processing & $S F 3 B 1$, XPO1, RPS15, DOX3X, ZNF292, MED12, NXF1 \\
DNA-damage and cell-cycle-control & $A T M$, TP53, POT1 \\
Chromatin-modification & $C H D 2$, ZMYM3, BAZ2A, ASXL1, SETD2 \\
Notch-signaling & NOTCH1, FBXW7 \\
Inflammatory & $B I R C 3$, MYD88, TRAF3, SAMHD1 \\
MAPK-ERK & $B R A F$, KRAS, MAP2K1, NRAS \\
WNT-signaling and MYC-related & $M G A, P T P N 11$ \\
BCR-signaling & $E G R 2, P A X 5$, BCOR, IRF4, IKZF3 \\
\hline
\end{tabular}

MAPK, Mitogen-activated protein kinases; ERK, extracellular signal-regulated kinases; WNT, wingless/integrated; BCR, B-cell receptor.

regard, mutations in U-CLL patients are more often found in coding regions of driver genes, and mutations in M-CLL tend to target promoter and enhancer regions. Moreover, the former mutations carry signatures suggesting a mutation mechanism associated with aging, whereas the latter suggest a mechanism associated with activation-induced cytidine deaminase (AID) activity (Burns et al. 2018). These mutational mechanisms have been suggested as active in CLL, albeit not in an IGHV-defined subset setting (Alexandrov et al. 2013; Kasar et al. 2015).

\section{Influences of B-Lymphocyte Surface Receptors on CLL}

In addition to genetic and environmental factors, normal B lymphocytes are influenced by cell-autonomous and cell-extrinsic signals that promote clonal survival and expansion.

\section{Signals Initiated by the $B$-Cell Receptor for Antigen}

Normal B lymphocytes respond to insults (often microbial) from the exterior and from within. In each instance, engagement of (auto)antigens by the smIg of the B-cell receptor (BCR) transmits an activating signal leading to survival and growth or anergy or death (Fig. 2). Based on structural studies of variable domains of Igs made by the leukemic B lymphocytes, the (auto)antigens they can bind, and the consequences of initiating such signals in vitro, it appears CLL B cells respond similarly to such inputs.
Consistent with derivation from a human B-cell subpopulation analogous to the murine $\mathrm{CD}^{+} / \mathrm{Lyl}^{+} / \mathrm{B1}^{+} \mathrm{B}$-cell subset (Hayakawa et al. 1983), initial studies of the genes coding for the variable domains of CLL Igs suggested these were restricted in use (Fong et al. 1985; Kipps et al. 1988) and were minimally, if at all, different from the germline sequence (Meeker et al. 1988; Pratt et al. 1989; Küppers et al. 1991; Friedman et al. 1992; Wagner and Luzzatto 1993; Pan et al. 1996). Subsequent studies confirmed restricted gene use (Johnson et al. 1997; Fais et al. 1998; Widhopf and Kipps 2001; Kröber et al. 2002; Ghiotto et al. 2006; Hadzidimitriou et al. 2009), although a review of available CLL sequences (Schroeder and Dighiero 1994) and prospective analyses of $\operatorname{IgG}^{+}$(Hashimoto et al. 1995) and $\operatorname{IgM}^{+}$(Fais et al. 1998) clones showed that $>50 \%$ of randomly chosen $\operatorname{IgM}^{+}$CLL cases as well as $\sim 75 \%$ of $\operatorname{IgG}^{+}$and $\operatorname{IgA}^{+}$cases exhibited significant numbers of $I G H V$ mutations $(>2 \%$ differences from the most similar germline gene). Thus, CLL clones are molecularly heterogeneous and can be subgrouped based on IGHV gene mutations. Notably, these two CLL types, M-CLL and U-CLL, have dramatically different clinical courses and outcomes (Damle et al. 1999; Hamblin et al. 1999), and segregating CLL patients this way is a valuable prognostic indicator for patient outcome.

Furthermore, certain CLL IGs have remarkably similar amino acid IGHV-IGHD-IGHJ rearrangements with characteristic HCDR3 amino acid motifs (Tobin et al. 2003, 2004; Ghiotto et al. 2004; Messmer et al. 2004; Stamatopoulos 


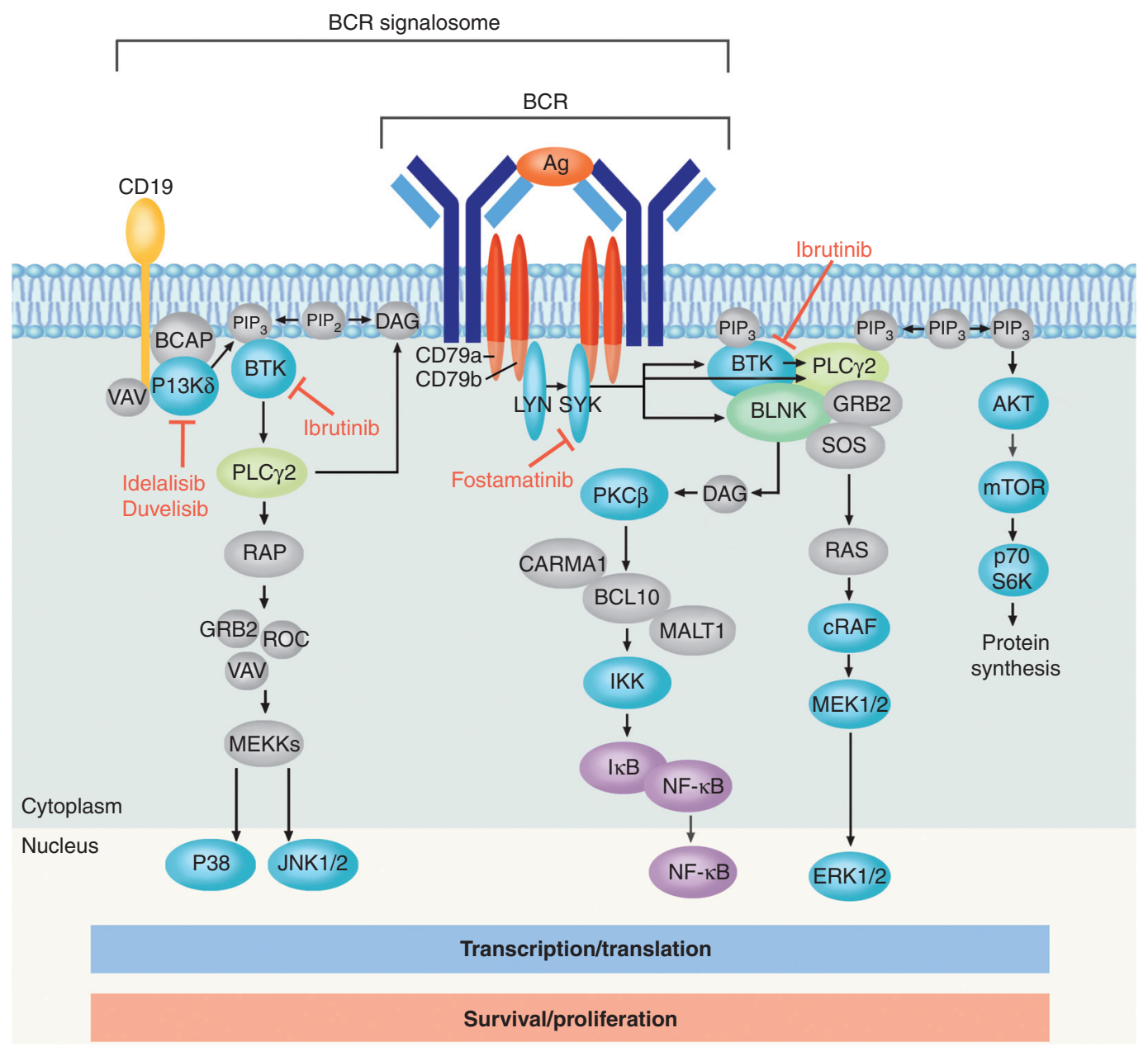

Figure 2. B-cell receptor (BCR) signaling pathway and the effects of kinase inhibition. Upon antigen interaction with the membrane IG component of the BCR, Lyn is activated and in turn phosphorylates CD79 on tyrosine residues-in particular, those in ITAM motifs. This permits binding of SYK and various adaptor molecules that initiate signaling that proceeds through key kinases including BTK, PI3K $\delta$, and AKT. (For a comprehensive review, see Slupsky [2014)].) The sites of action for kinase inhibitors are indicated: BTK (ibrutinib), PI3K $\delta$ (idelalisib), PI3K $\delta+\gamma$ (duvelisib), and SYK (fostamatinib).

et al. 2007, 2017; Vardi et al. 2014; Agathangelidis et al. 2019); these are referred to as "stereotyped BCRs" (Messmer et al. 2004). The likelihood such rearrangements occur by chance is infinitesimally small $\left(10^{-12}\right)$, indicating selection of normal B lymphocytes with defined and in some cases quasi-unique BCR structures rarely found in large amounts in the normal B-cell repertoire. Stereotyped BCRs are found in 33\% of CLL cases (Stamatopoulos et al. 2007; Murray et al. 2008; Agathangelidis et al. 2012, 2019).
When considering U-CLL, $\sim 50 \%$ of cases fall into a stereotyped subset.

Foreign or autologous antigens engage smIg leading to a series of stimulatory events activating various B-cell fates: survival, expansion, anergy, or death. The state or type of B cell as well as concomitant signals delivered via membrane molecules on other cells or their secreted factors determine which fate occurs. For CLL cells, the antigens or classes of antigens involved are foreign (e.g., viral [Steininger et al. 2012], fungal 
[Hoogeboom et al. 2013], and bacterial [Hatzi et al. 2016]) or autologous (e.g., self-antigens characteristic of autoimmune disorders [Bröker et al. 1988; Sthoeger et al. 1989; Borche et al. 1990; Hervé et al. 2005]) and self-antigens developing during apoptosis or normal catabolism (Catera et al. 2006; Chu et al. 2008, 2010; Lanemo Myhrinder et al. 2008). B-cell interactions with antigens that support survival and expansion most likely occur in solid tissues where most CLL cells divide (Calissano et al. 2011; Herishanu et al. 2011; Herndon et al. 2017) and hematopoietic and nonhematopoietic cells support survival and expansion.

Another important type of autoreactivity characteristic of CLL IGs is their ability to bind themselves (Binder et al. 2011, 2013; Dührenvon Minden et al. 2012), leading to self-association/homodimerization (Minici et al. 2017). This interaction results in BCR signaling without binding antigenic epitopes external to the $\mathrm{B}$ cell and extrinsic to the BCR, referred to as "autonomous signaling" (Dühren-von Minden et al. 2012). Although not yet studied thoroughly, the affinity of self-association, and hence the frequency of autonomous signaling, correlates with patient outcome: High affinity correlates with better outcome and low affinity with bad outcome (Minici et al. 2017). It has been suggested that this type of signaling promotes survival or anergy, whereas signaling resulting from smIg binding of non-IG antigens leads to proliferation (Chiorazzi and Efremov 2013). Selfassociation/autonomous signaling occurs in normal pre-B cells (Köhler et al. 2008; Eschbach et al. 2011) and B-1 cells in mice (Köhler et al. 2008), and findings from a mouse model of CLL support its importance in the human disease (Iacovelli et al. 2015).

\section{Signals Initiated by Other Membrane- Associated Pathways}

Several other signaling pathways affect the biology of CLL cells. The C-X-C-motif chemokine receptor-4 (CXCR4) is critical in allowing CLL cells to traffic to survival niches in solid tissues (Burger and Bürkle 2007) and delivers survival signals to normal B lymphocytes and CLL cells
(Burger and Kipps 2002). Similarly, CD38 and CD49d, two membrane molecules whose levels of expression correlate with clinical course in CLL (Damle et al. 1999; Bulian et al. 2008; Gattei et al 2008; Rossi et al. 2008; Shanafelt et al. 2008a), deliver trophic signals to CLL cells (Deaglio et al. 2003, 2007; Zucchetto et al. 2009, 2012; Vaisitti et al. 2010). The orphan receptor ROR1 , initially identified by gene expression analyses of CLL B cells (Klein et al. 2001; Rosenwald et al. 2001) and subsequently found on CLL cells (Baskar et al. 2008; Daneshmanesh et al. 2008; Fukuda et al. 2008), delivers signals, either constitutively (Hojjat-Farsangi et al. 2013) or after interacting with Wnt family ligands (Yu et al. 2016). Because ROR-1 signaling promotes CLL cell survival, growth, and migration (Cui et al. 2016; Hasan et al. 2017, 2019; Yu et al. 2017) and ROR-1 is expressed only on CLL cells and certain other Bcell lymphoproliferative disorders and not on immature and mature normal B lymphocytes (Broome et al. 2011), targeting the molecule is a potential therapy (Yang et al.2011). Clinical trials with anti-ROR-1 monoclonal antibodies (mAbs) (Choi et al. 2015) and with chimeric antigen-receptor (CAR)-T cells bearing anti-ROR-1 mAbs (Hudecek et al. 2010) are under way.

\section{Other Microenvironmental Signals Associated with Clonal Expansion}

Other hematopoietic and nonhematopoietic cells foster clonal expansion, either by cell-cell contact or by elaborating cytokines and chemokines (Fig. 1B). For example, nurse-like cells, a CLL equivalent of tumor-associated macrophages (Tsukada et al. 2002), secrete the CXCR4 ligand, CXCL12; this attracts leukemic $B$ cells to these trophic elements that secrete BAFF and APRIL (Nishio et al. 2005). Additionally, classical macrophages, particularly those of the M2 type, promote survival, and elimination of these cells prevents CLL-cell growth (Galletti et al. 2016; Hanna et al. 2016). In addition, although $\mathrm{T}$ lymphocytes in CLL are defective in interacting with leukemic B cells (Ramsay et al. 2008) and hence do not effectively carry out cytolysis, they do promote survival and expansion in vitro (Granziero et al. 2001; Os et al. 2013) and 


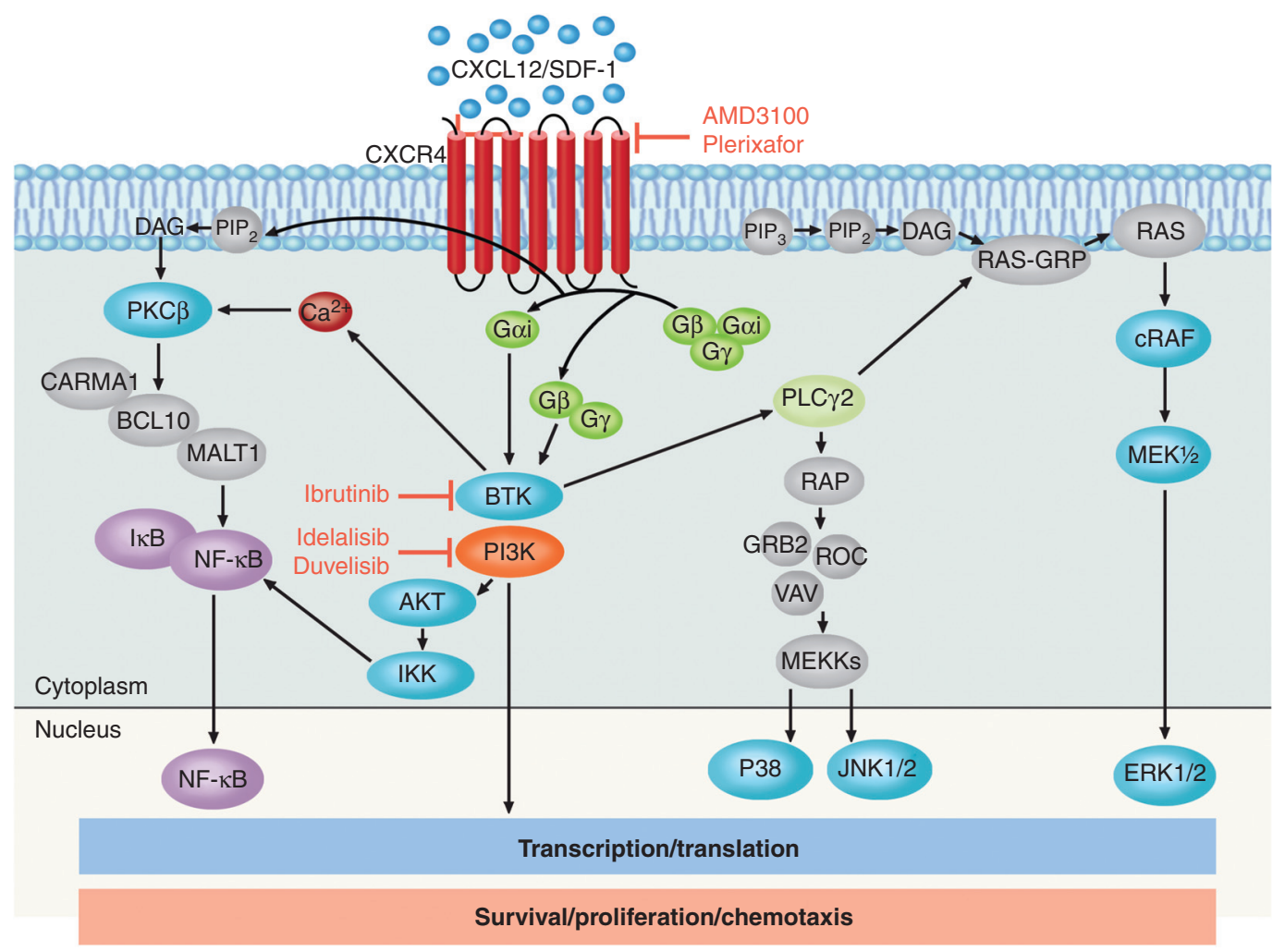

Figure 3. CXCR4 signaling pathway and the effects of kinase inhibition. CXCR4 (C-X-C-motif chemokine receptor-4) is a G protein-coupled receptor (GPCR) that binds CXCL12/stromal-derived-factor-1 (SDF-1). CXCR4 signaling in response to CXCL12/SDF-1 mediates migration of circulating CLL cells. As a GPCR, CXCR4 engagement activates $\mathrm{G}$ protein-mediated signaling resulting in intracellular $\mathrm{Ca}^{2+}$ flux and subsequent activation of downstream pathways such as Ras and PI3K $\delta$. Activated JNK and PI3K $\delta$ signaling lead to cell survival and migration. CXCR4 induces downstream signaling by several pathways such as those involving BTK and PLC 22 signaling. Blocking CXCR4 signaling can be achieved by AMD3100 and plerixafor, which prevent CXCR4/SDF-1 binding, and by BTK inhibitor by ibrutinib. Other small molecular inhibitors like idelalisib and duvelisib target PI3K to block CXCR4 downstream signaling.

in xenografts (Bagnara et al. 2011; Patten et al. 2016). CLL cells, especially from poor-outcome U-CLL patients, secrete CCL3 and CCL4 that draw $T$ cells into their vicinity, thereby receiving trophic signals (Burger et al. 2009). IL-4 is especially relevant for survival and reprogramming smIg expression (Fig. 3; Aguilar-Hernandez et al. 2016; Guo et al. 2016). Finally, mesenchymal stromal cells support CLL-cell survival by secreting cytokines and chemokines (Trimarco et al. 2015), as do vascular endothelial cells expressing CD31, the co-receptor for CD38 on hematopoietic cells including CLL cells (Deaglio et al. 1996, 2000).

\section{Monoclonal B-Cell Lymphocytosis}

B lymphocytes bearing a CLL phenotype can be found in the blood of normal individuals, in some instances years before the diagnosis of CLL (Landgren et al. 2009; Georgiadis et al. 2017). This condition, termed monoclonal Bcell lymphocytosis (MBL), is defined by elevated numbers of $\mathrm{CD}^{+} \mathrm{CD} 19^{+} \mathrm{CD} 20^{\text {low }} \mathrm{CD} 79 \mathrm{~b}^{\text {low }} \mathrm{Ig}^{\text {low }}$ cells in the blood and no evidence for CLL or small lymphocytic lymphoma (SLL) (Marti et al. 2005; Shanafelt et al. 2010).

MBL is surprisingly common. Approximately $5 \%$ of the general population after the 
N. Chiorazzi et al.

age of 40 has MBL, increasing to $15 \%$ after the age of 70 (Rawstron et al. 2002a; Ghia et al. 2004). Moreover, first-degree relatives in familial CLL cohorts have a $\sim 15 \%$ incidence of MBL after the age of 40 , and first-degree relatives in families with sporadic CLL have a similar incidence after age 60 (Rawstron et al. 2002b; Marti et al. 2003; Matos et al. 2009; Goldin et al. 2010). Because annually only $1 \%$ of subjects with MBL progress to CLL requiring therapy (Rawstron et al. 2002a,b; Fung et al. 2007; Rossi 2009a; Shanafelt et al. 2009b; Molica et al. 2011), additional events, most likely genetic aberrations, are needed to usher this common condition to leukemia. Elevated serum $\beta_{2}$-microglobulin levels and expression of an unmutated IGHV by the MBL clone predict a shorter transformation time to CLL (Parikh et al. 2018).

The common genetic abnormalities (Rawstron et al. 2008; Shanafelt et al. 2009a; Molica et al. 2011) and susceptibility loci (CrowtherSwanepoel et al. 2010b) characteristic of CLL are found in MBL. Although limited, genetic studies using next-generation sequencing (NGS) reveal similarities between $\mathrm{MBL}$ and early-stage CLL (Rasi et al. 2012; Greco et al. 2013; Ojha et al 2014; Agathangelidis et al. 2018; Popp et al. 2019). MBL and CLL samples have similar mutation burdens; however, when analyzed for specific driver mutations, less are found in MBL (Puente et al. 2015), consistent with the stepwise evolution from one to the other.

Finally, as in CLL, there are implications for a more global immune defect in people with MBL. Such individuals have a higher incidence of severe infections (Lesley et al. 2009; Casabonne et al. 2012; Moreira et al. 2013) and nonhematologic cancers (Solomon et al. 2016) and may have an increased incidence of hypogammaglobulinemia (Glancy and Siles 2016).

\section{Normal Cell Equivalents of Full-Fledged CLL B Cells}

CLL cells are identified by CD5 expression and hence could be derived from a normal $\mathrm{CD}^{+} \mathrm{hu}-$ man B lymphocyte. It is believed that this human B-cell subset is evolutionarily aligned with the murine B-1 subset (Hayakawa et al. 1983). Al- though murine $\mathrm{CD}^{+} \mathrm{B}-1$ cells have been extensively studied, it is controversial whether they derive from a one-of-a-kind hematopoietic precursor, hence embodying a distinct B-cell lineage (Montecino-Rodriguez et al. 2006; Ghosn et al. 2011), or represent sets of B lymphocytes that acquire a unique surface membrane phenotype and functional features based on the maturational path followed during development (Haughton et al. 1993). The same conundrum exists for CLL -that is, one precursor cell type that follows different maturation stages, thereby accumulating or not somatic IGHV mutations, or two (or more) fundamentally distinct precursors. Candidate precursors include mature $\mathrm{CD}^{+} \mathrm{B}$ cells (Seifert et al. 2012) and a B-cell subset bearing the $\mathrm{CD} 20^{+} \mathrm{CD} 27^{+} \mathrm{CD} 43^{+} \mathrm{CD} 70^{-}$surface membrane phenotype (Griffin et al. 2011).

Because CLL B cells fall into two categories based on $I G H V$ gene mutations, it has been suggested U-CLL cells derive from naive B lymphocytes and M-CLL from memory B cells. However, because both CLL subtypes appear to be chronically activated cells based on membrane phenotype (Damle et al. 2002), telomere lengths (Damle et al. 2004; Strefford et al. 2015), gene expression profiling (Klein et al. 2001; Rosenwald et al. 2001), and epigenetic analyses (Oakes et al. 2016), precursors for both CLL subtypes are likely antigen-experienced. In this regard, because U-CLL clones can spontaneously (Gurrieri et al. 2002; Bagnara et al. 2006) or upon stimulation (Patten et al. 2012, 2016) acquire new IGHV mutations, it is possible the lack of mutations in the majority of cells in these clones is due to the developmental path the normal B cell followed prior to transformation (Chiorazzi and Ferrarini 2003).

Collectively, the above suggests CLL develops in genetically susceptible people upon exposure to still ill-defined environmental antigens possibly acting in concert with common autoantigens. This might be a stepwise process beginning early in hematopoietic and B-cell ontogeny and ending in cells downstream in the B-cell developmental pathway at a point after rearrangement of the IGHV-IGHD-IGHJ and $I G L V$-IGLJ segments (Fig. 1A). This selection is mediated either by classical interactions of 
smIg with (auto)antigens or by smIg self-association and consequent autonomous signaling. Chronic stimulation over time, probably due to ongoing stimulation through the BCR and possibly other pathways (e.g., TLR9 or TLR7), leads to repetitive rounds of DNA replication and development of genetic abnormalities that complement each other and create a leukemic clone. This occurs in normal B cells selected for transformation based on the structure of their BCRs.

\section{DIAGNOSIS AND INITIAL TREATMENT OF CLL}

\section{Clinical and Laboratory Parameters}

In most western countries in which health care is readily accessible, diagnosis of CLL is made during a routine medical visit by finding an elevated number of lymphocytes on a complete blood count. If lymphocyte expansion persists, flow cytometric analysis of the number of $\mathrm{CD}^{+} \mathrm{CD} 19^{+} \mathrm{B}$ cells is carried out, searching for an increased number of cells with low levels of smIg of a single IG L chain type co-expressing CD20, CD79b, and CD23. Because most patients are asymptomatic at this time, clinical history is often not revealing, although weight loss, lethargy, night sweats, and complaints of "swollen glands" may be reported. Physical examination focuses on identifying lymphadenopathy and hepatosplenomegaly and evidence of red blood cell or platelet deficiencies. Guidelines for the diagnosis and treatment of CLL have recently been updated (Hallek et al. 2018).

\section{Prognostic Markers}

Upon diagnosis of CLL, a series of prognostic indicators may assist in defining the stage of the disease and in predicting the clinical course that an individual patient will follow. Clinical stage is assigned according to algorithms defined by Rai et al. (1975) or Binet et al. (1981), using physical findings and the results of a complete blood count. These time-honored approaches remain the mainstays of clinical care.

Predictions of clinical course and outcome can be made by analyzing a series of laboratory parameters. Perhaps the most reliable prognostic indicator is "IGHV mutation status": the presence or absence of significant numbers of somatic mutations in the $I G H V$ gene expressed by the CLL clone. As discussed, CLL clones can be divided into two categories, based on mutations in the heavy chain variable gene, IGHVunmutated (" $\mathrm{U}-\mathrm{CLL} ; \leq 2 \%$ difference from the most similar germline gene) and IGHV-mutated ("M-CLL"; > $\%$ difference from the most similar germline gene) (Schroeder and Dighiero 1994; Hashimoto et al. 1995; Fais et al. 1998), with patients bearing a U-CLL clone having a more aggressive clinical course (Damle et al. 1999; Hamblin et al. 1999).

Other cell-based indicators suggesting an inferior clinical course include increased percentages of CLL cells bearing membrane CD38 (Damle et al. 1999) or CD49d (Shanafelt et al. 2008a; Bulian et al. 2014; Baumann et al. 2016) or intracellular levels of ZAP70 (Crespo et al. 2003; Rassenti et al. 2008). Furthermore, $\beta_{2}$-microglobulin (Simonsson et al. 1980; Di Giovanni et al. 1989; Keating et al. 1995) and thymidine kinase (Hallek et al. 1999) serum levels provide prognostic information; the former is easier to analyze and is preferred in clinical settings.

Finally, serial absolute lymphocyte counts afford helpful information. Patients whose absolute lymphocyte counts double in $<1 \mathrm{yr}$ are more likely to follow an aggressive course (Montserrat et al. 1986; Molica and Alberti 1987).

\section{Predictive Markers}

Whereas prognostic markers try to presage the likelihood of disease progression and hence clinical outcome, predictive markers try to foresee the response to a given therapy (Oldenhuis et al. 2008; Mandrekar and Sargent 2010; Zenz et al. 2010b; Montserrat 2012). Because CLL is a heterogeneous disease at the clinical and molecular levels, it is difficult to define parameters that best predict outcome to a specific therapy. Moreover, because the therapies for CLL are currently under major flux, the principles defined for one approach might not apply to another. With these caveats in mind, genetic abnormalities, 
N. Chiorazzi et al.

particularly loss or mutation of TP53, are predictive for certain therapies. Patients with TP53 disruption do not respond to chemoimmunotherapy and might be compromised by it (Gonzalez et al. 2011). Moreover, although patients with this genetic lesion respond to signaling inhibitors better than to chemoimmunotherapy, these patients are more likely to relapse (Byrd et al. 2015; Farooqui et al. 2015). Additionally, the presence of mutations in NOTCH1 can signal ineffectiveness of anti-CD20 mAb treatment because of diminished numbers of membrane CD20 molecules (Pozzo et al. 2016).

Possibly the most reliable predictive indicator for patients treated with chemotherapy and chemoimmunotherapy is the level of minimal residual disease (MRD) detectable after therapy. MRD is evaluated using multiparameter flow cytometry (Rawstron et al. 2013; Böttcher 2019), using polymerase chain reaction detection of the signature VH CDR3 segment of the CLL clone (van Dongen et al. 2003), and, recently, by next-generation deep sequencing of the CLL IGHV-IGHD-IGHJ rearrangement (Logan et al. 2011, 2013; Rawstron et al. 2015; Rodríguez-Vicente et al. 2017).

The extent of MRD independently predicts progression-free survival and overall survival in patients receiving various chemotherapy and chemoimmunotherapy regimens in the front-line, follow-up, and consolidation settings (Böttcher et al. 2012; Kwok et al. 2016; Varghese et al. 2017). Hence, MRD can be used as a surrogate for progression-free survival in therapeutic clinical trials (Dimier et al. 2018). However, a role for MRD in patients treated with the signaling pathway inhibitors or anti-BCL2 therapy is not clear, especially for the former because most patients receiving these medications continue to have detectable leukemic cells.

\section{Combinatorial Indices}

Because of the complexity and variability in clinical course and in leukemia-cell biology in individual patients, combinatorial algorithms incorporating several prognostic and predictive markers have been devised to better predict outcome and response to therapy (Wierda et al. 2007, 2011; Molica et al. 2010; Rossi et al. 2013).

The Chronic Lymphocytic Leukemia International Prognostic Index (CLL-IPI) incorporates patient age, disease stage (Rai or Binet systems), TP53 disruption, IGHV mutation status, and serum $\beta 2$-microglobulin levels (International CLL-IPI Working Group 2016). These five parameters are weighted individually, and a composite score assigns patients to one of four risk groups. Another algorithm using only IGHV mutations and high-risk fluorescence in situ hybridization (FISH) cytogenetics (del17p and del11q) divides CLL patients into three groups: low-risk, comprised of M-CLL clones without high-risk cytogenetics; intermediaterisk, containing either U-CLL or high-risk cytogenetics; and high-risk, consisting of U-CLL and high-risk cytogenetics (Delgado et al. 2017). Time to first treatment and overall survival follow the order of the risk categories for both approaches. Should the same conclusions be drawn for treatments with the signaling inhibitors and the BCL-2 family blocker (Molica et al. 2018), these might eventually be useful in daily practice and to stratify patients in clinical trials.

Finally, despite the information that prognostic, predictive, and combination indicators suggest, the decision to begin therapy in clinical practice is still based on an educated synthesis of patient information and symptoms, physical examination findings, and laboratory data to define active disease (Hallek et al. 2018).

\section{Options for the Initial Treatment of CLL}

A physician treating CLL patients in 2019 has many previously unavailable options. Because most CLL patients are aging and might have compromised organ systems that reduce treatment tolerability, patient fitness and comorbidities influence therapy goals (complete remission vs. symptom alleviation/palliation). Table 3 provides therapeutic options for patients in various fitness and disease categories. At this point, the most frequently employed are chemoimmunotherapy, $\mathrm{mAbs}$ to B-cell surface molecules, and inhibitors of signaling and anti-apoptotic pathways. 
Chronic Lymphocytic Leukemia
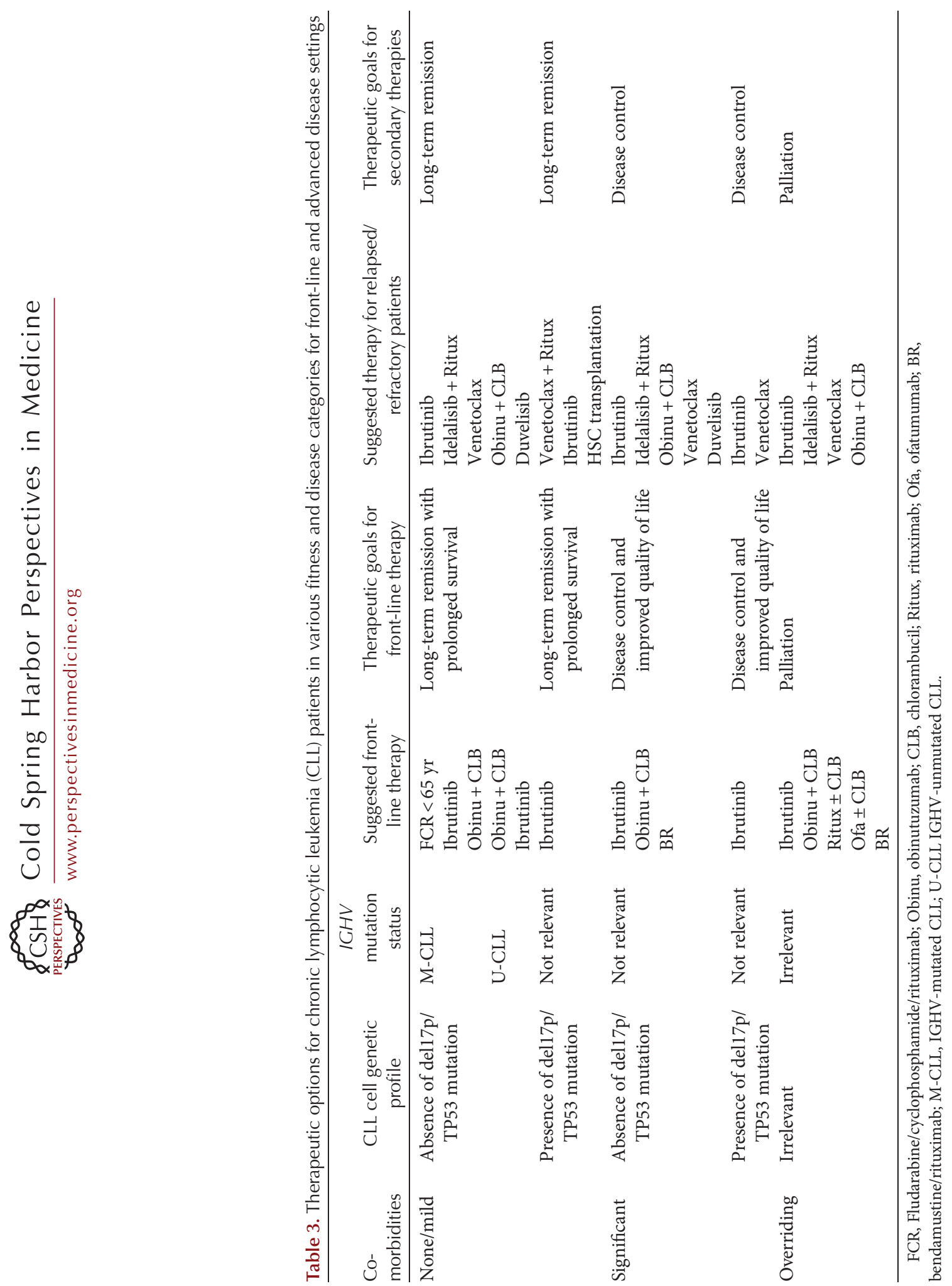
N. Chiorazzi et al.

\section{Chemoimmunotherapy}

Historically, chemotherapy has been the mainstay of cancer therapy, with addition of mAbs leading to improved regimens. In CLL, fludarabine plus cyclophosphamide (FC) were synergistic (Keating et al. 1989; Yamauchi et al. 2001); adding rituximab (FCR) resulted in an even more effective regimen (Keating et al. 2005; Tam et al. 2008; Hallek et al. 2010; Fischer et al. 2016; Thompson et al. 2016). Presently, FCR is considered state-of-the-art therapy for physically fit CLL patients. Remarkably, $\sim 50 \%$ of previously untreated M-CLL patients are alive without progression at $\sim 13 \mathrm{yr}$, compared to only $<10 \%$ of U-CLL patients (Thompson et al. 2016), suggesting this treatment may cure some M-CLL patients. Studies with shorter follow-up times (Fischer et al. 2016) and fewer cases (Rossi et al. 2015) report similar results, although high serum $\beta_{2}$-microglobulin levels and del17p and/ or del11q herald less durable remissions (Rossi et al. 2015). Bone marrow (BM) and immune suppression following this regimen (Benjamini et al. 2015), however, raise concerns about secondary malignancies, especially in patients receiving FCR as frontline therapy (Zhou et al. 2012; Benjamini et al. 2015; Falchi et al. 2016).

\section{Monoclonal Antibodies}

Three anti-CD20 mAbs, classified as Type I or II based on binding properties (Beers et al. 2010), are approved for use in CLL. Type I mAbs (rituximab and ofatumumab) effectively promote cytotoxicity but are less effective at inducing apoptosis (Cragg et al. 2003), whereas type II (obinutuzumab) is superior at inducing apoptosis but inferior at carrying out cytotoxicity (Chan et al. 2003). In previously untreated CLL patients, type II obinutuzumab, in combination with chlorambucil, is superior to type I rituximab plus chlorambucil (Goede et al. 2014).

\section{Specific Pathway Inhibition}

Studies associating unique structural BCR features with clinical outcome and differences in signaling capacities brought small molecules blocking enzymes critical for this signaling pathway into the clinic. Orally administered inhibitors of Bruton's tyrosine kinase (Btk), ibrutinib, and of phospatidylinositol-4,5-bisphosphate 3kinase delta (PI3K $\delta$ ), idelalisib, yielded dramatic responses in relapsed/refractory patients by blocking signaling through the BCR, chemokine receptors, and integrins (Figs. 2 and 3; Spaargaren et al. 2003; Ortolano et al. 2006; de Gorter et al. 2007; de Rooij et al. 2012; Herman et al. 2015; Maffei et al. 2015; Chen et al. 2016). Ibrutinib is efficacious in patients with del17p, del11q, and unmutated IGHV (Farooqui et al. 2015) and in patients refractory or unresponsive to other therapies (Byrd et al. 2013; Furman et al. 2014b). Both molecules inhibit cell replication (Herman et al. 2011, 2014a; Ponader et al. 2012), trafficking to/retention in lymphoid tissues (Niedermeier et al. 2009; Herman et al. 2011, 2014a,b; Ponader et al. 2012; Fiorcari et al. 2013; Göckeritz et al. 2015), and production of pro-inflammatory cytokines (Ponader et al. 2012; Herman et al. 2014a; Niemann et al. 2016). Upon initiating ibrutinib or idelalisib therapy, lymphadenopathy and splenomegaly rapidly regress and peripheral blood lymphocyte counts increase because of redistribution of cells from tissue compartments to the blood (Woyach et al. 2014b; Chen et al. 2016; Burger et al. 2017). In most patients, lymphocytosis diminishes over time and circulating B-cell numbers in the blood fall to or below pretreatment levels. Ibrutinib is FDA-approved for first- and second-line therapy of CLL and for patients with del17p; idelalisib in combination with rituximab is approved for relapsed CLL. Recently, an inhibitor of both $\mathrm{PI} 3 \mathrm{~K} \delta$ and $\mathrm{PI} 3 \mathrm{~K} \gamma$ (duvelisib) was approved for the treatment of relapsed/refractory CLL and SLL (Flinn et al. 2018).

As single agents, these medications rarely lead to complete remissions (Burger et al. 2010). Also, occurrence of long-term side effects and development of resistance have not been fully investigated. Ibrutinib and idelalisib are generally well-tolerated, and severe side effects occur in a minority of patients (de Weerdt et al. 2017). For ibrutinib, these are bleeding (Lipsky et al. 2015), hypertension (Caldeira et al. 2019), and atrial fibrillation (McMullen et al. 2014; 
Lentz et al. 2019). For idelalisib, neutropenia and inflammatory reactions (Brown 2014; Furman et al. 2014b), particularly in treatment-naive patients (Lampson et al. 2016), are major adverse events, and hence idelalisib plus rituximab is reserved for relapsed, refractory disease.

\section{Targeting Anti-Apoptotic Proteins}

CLL lymphocytes characteristically overexpress anti-apoptotic BCL-2 (Schena et al. 1992), the parent molecule in a family of proteins controlling suppression or initiation of apoptosis (Adams and Cory 2018). BCL-2 family members containing BCL-2 homology domain-3 (BH3only proteins) promote apoptosis by blocking pro-survival members of the family (RuefliBrasse and Reed 2017). Venetoclax, an orally administered $\mathrm{BH} 3$-protein mimetic selectively targeting BCL-2 (Souers et al. 2013), is effective in refractory CLL patients with del17p, del11q, or $I G H V$-unmutated clones (Anderson et al. 2016) and is FDA-approved for previously treated CLL patients bearing del17p clones. Overall remissions and complete remissions have been achieved in $82 \%$ and $10 \%$ of patients, respectively, and in 5\%, residual disease was not detectable at 15 mo (Roberts et al. 2016). Because of the propensity to cause tumor lysis syndrome, patients are started on very low drug doses initially.

\section{DISEASE PROGRESSIONAND THERAPEUTIC REFRACTORINESS TO INITIAL THERAPY}

\section{Factors Promoting Development of More} Aggressive Clonal Variants

Like other cancers, progression of CLL develops from the emergence of intraclonal variants with genetic changes fostering growth, survival, and therapeutic resistance. These disrupt the balance between cellular proliferation and death (Chiorazzi 2007) and in some patients become a major component of the leukemic clone. Such variants can develop spontaneously or are generated by processes inherent to normal cells or unique to a cancer cell; certain treatments targeting replicating DNA can do the same.
CLL cells contain high levels of reactive oxygen species (Oltra et al. 2001; Zhou et al. 2003), a characteristic of cancer cells, which can act as mutagens (Cerutti 1994; Wiseman and Halliwell 1996; Nogueira and Hay 2013). Also, as B lymphocytes, CLL cells can make the mutagenic enzyme, AID (Albesiano et al. 2003; McCarthy et al. 2003; Oppezzo et al. 2003). AID carries out a normal role in the development of more effective immune responses by inducing mutations in genes coding the variable domains of Abs/IGs (IGHV, IGHD, IGHJ and IGLV, IGLJ) and in the gene segments that support switching from IgM to IgG, IgA, and IgE (Muramatsu et al. 1999, 2000). However, AID can act aberrantly, creating mutations outside IG loci (Pasqualucci et al. 1998; Yamane et al. 2011), leading to genetic changes and B-cell lymphomas (Pasqualucci et al. 2001; Lenz et al. 2007; Robbiani et al. 2009).

A small fraction $(\sim 0.01 \%-1 \%)$ of circulating CLL B cells express AID mRNA (Albesiano et al. 2003), and so AID protein is rarely detectable (Pasqualucci et al. 2004). However, CLL cells in tissue proliferation centers (Leuenberger et al. 2010; Patten et al. 2012) and those activated in vitro (Cerutti et al. 2002; Albesiano et al. 2003; Oppezzo et al. 2003) and growing in xenografts (Patten et al. 2016) synthesize AID protein, consistent with the link of AID production to cell division (Rush et al. 2005). The protein is functional as evidenced by detection of new, spontaneous mutations in the clonal IGHV-IGHD-IGHJ (Patten et al. 2012, 2016) and hence could create off-target mutations and intraclonal variants that might lead to disease progression. Although certain chemotherapeutic agents can induce DNA mutations (Tan et al. 2015), based on next-generation deep-sequencing analyses many/most mutations that emerge after cancer therapy in CLL patients are present before treatment. Mathematical modeling suggests this is likely for ibrutinib (Komarova et al. 2014). Also, because the drug prevents CLL B-cell division (Honigberg et al. 2010; Herman et al. 2011; Burger et al. 2017) and AID is produced upon cell proliferation (Rush et al. 2005), it is likely that additional clonal mutations are halted by ibrutinib. 
N. Chiorazzi et al.

\section{Clonal Evolution}

The common genetic abnormalities identified by FISH and the recurrent genetic mutations defined by NGS (Table 1) have been used to follow clonal evolution in patients (Finn et al. 1998; Shanafelt et al. 2008b; Landau et al. 2013, 2014a, 2015; Lawrence et al. 2013; Nadeu et al. 2018). Similarly, epigenetic diversity can identify similar events (Kulis et al. 2012; Oakes et al. 2014; Landau et al. 2014b; Guièze and Wu 2015; Queirós et al. 2015; Mansouri et al. 2018). Resulting clonal architectures can be informative (Messina et al. 2014; Wang et al. 2014; Ojha et al. 2015). Whereas linear development from a starting genetic template is seen more often, branching patterns are also found (Braggio et al. 2012), indicating distinct intraclonal variants can evolve in parallel. These chronologic genetic and epigenetic variations provide insights into disease progression and into the clinical courses for individual patients (Quesada et al. 2013; Villamor et al. 2013; Rose-Zerilli et al. 2016).

\section{Role of CLL-Cell Growth Rate in Disease Progression}

CLL progresses at a slower rate than acute leukemias and more aggressive lymphomas, as reflected by clonal birth rates and by the relatively low baseline levels of genomic mutations. Approximately $0.1 \%-2 \%$ of a CLL clone is added daily, based on deuterium $\left({ }^{2} \mathrm{H}\right)$-labeling of replicating DNA provided as "heavy water" $\left({ }^{2} \mathrm{H}_{2} \mathrm{O}\right)$ to measure CLL B-cell growth in patients (Messmer et al. 2005; Defoiche et al. 2008; van Gent et al. 2008). Clonal birth rates directly correlate with clinical course, as patients with higher birth rates require treatment sooner (Murphy et al. 2017). Also, most CLL-cell growth occurs in lymph nodes (LNs) (Herndon et al. 2017), suggesting CLL cells divide in secondary lymphoid tissues and traffic to the BM, where they reside mostly in a resting state (Fig. 4; Calissano et al. 2011). This model for growth and survival based on tissue residence has been recapitulated in murine models (Chen et al. 2013). Hence, CLL cells at different anatomic sites can behave differently, which may relate to effectiveness of certain therapeutic agents.

\section{Relapsed/Refractory, Accelerated, and Transformed Disease}

Here we assume that first-line treatments mentioned in Table 1 have failed, and the patient again requires therapy. Consistent with clonal evolution and disease progression being a function of increased cell growth in LNs, patients in this category often have nodal, splenic, or extranodal disease. A suspicion of Richter's transformation (RT) (Richter 1928), often as diffuse large B-cell lymphoma (DLBCL) that has large $B$ cells with nuclear sizes more than twice that of a normal B lymphocyte, is raised when $\mathrm{LN}$ or spleen enlargement occurs rapidly and when extranodal sites are defined; elevated LDH levels are often found (Jain and Young 2014; Allan and Furman 2019). In those instances in which RT is not found, patients might have "accelerated CLL," defined by highly proliferative CLL cells in expanded, substantially more active proliferation centers that contain $\mathrm{T}$ cells, especially $\mathrm{CD}^{+}$cells, and dendritic cells. Although the frequencies of accelerated CLL and RT are only $\sim 23 \%$ and $\sim 10 \%$ of all CLLs, they are increased for those relapsed/refractory patients with adenopathy ( $\sim 25 \%$ accelerated CLL, $\sim 50 \%$ standard refractory CLL, and $\sim 25 \%$ RT) (Gine et al. 2010). Survival in the three categories are distinct: $\sim 76 \mathrm{mo}$ in nonaccelerated CLL, $34 \mathrm{mo}$ for accelerated CLL, and only 8-12 mo for RT.

The mechanisms leading to accelerated CLL and RT are unclear, although they might involve BCR and TLR signaling to stimulate CLL-cell proliferation (Balogh et al. 2011), especially stereotyped subset \#8 CLLs (Rossi et al. 2009b) that display polyreactivity to multiple antigens (Gounari et al. 2015). The lymphoma that develops in RT is usually clonally related to the CLL clone (Mao et al. 2007), and when that is the case the outcome for the patient is worse than if the lymphoma has a distinct genetic origin (Condoluci and Rossi 2017). Several genetic alterations are associated with RT: elevated AID levels in leukemic B cells (Reiniger et al. 2006), disruption of TP53 and CDKN2A, and activation of NOTCH1 and c-MYC (Fabbri et al. 2013). TP53 and CDKNA2 mutations are found in $>50 \%$ of cases, whereas trisomy 12 and 


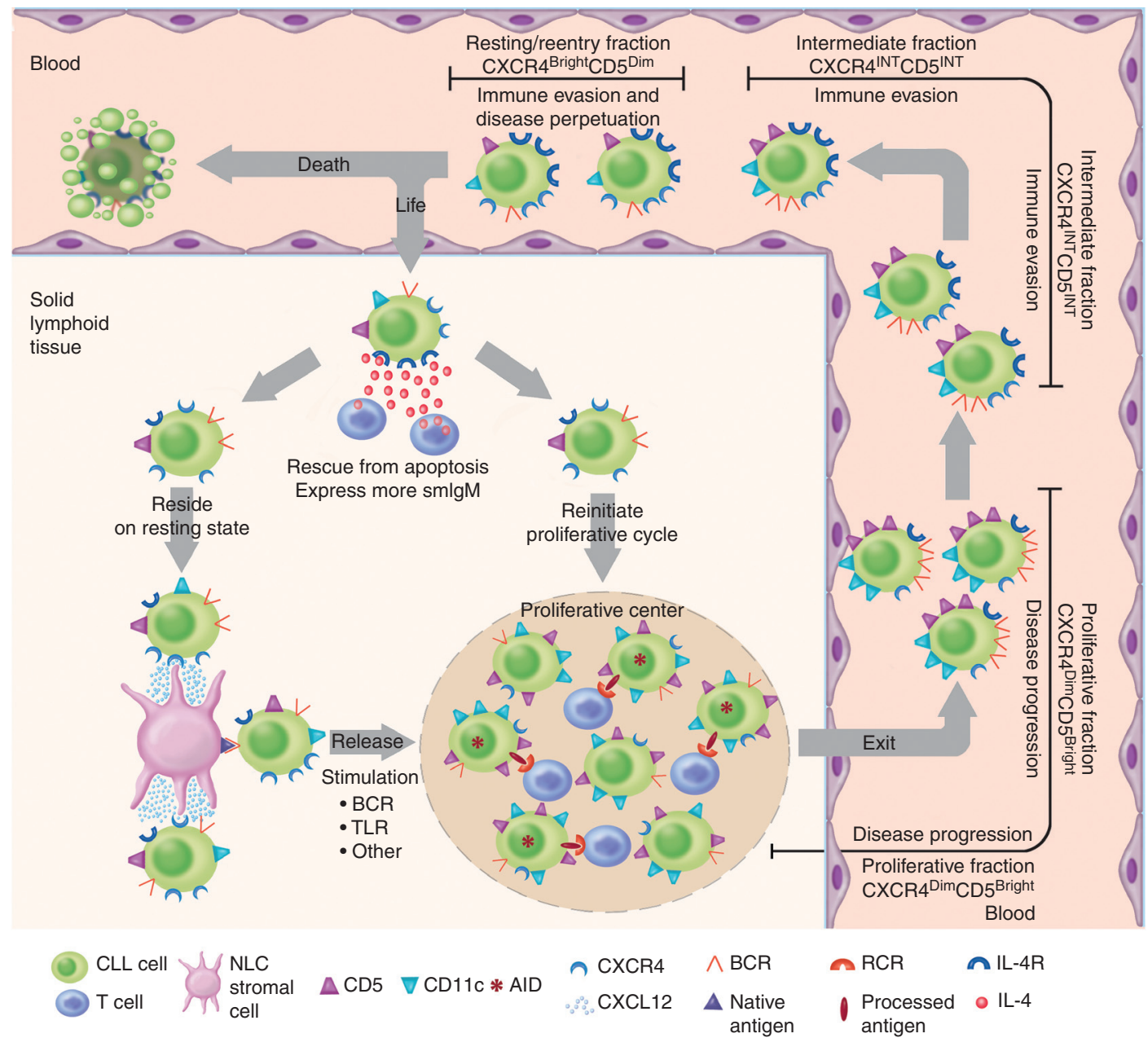

Figure 4. Life cycle of a chronic lymphocytic leukemia (CLL) B lymphocyte. In primary and secondary lymphoid tissues (bottom left) CLL B lymphocytes nestle, in a resting state, on survival-nurturing cells (e.g., nurse-like cells [Burger et al. 2000] or less well-defined, nonhematopoietic "stromal cells"). Docking is facilitated by several receptor-ligand interactions, including CXCL12-CXCR4. When cell division initiates, spontaneously or after stimulation via receptors (e.g., B-cell receptor [BCR] or Toll-like receptors [TLRs]), cells internalize CXCR4, detach, and migrate to structures resembling germinal centers ("proliferation centers" [Swerdlow et al. 1984; Schmid and Isaacson 1994; Bonato et al. 1998]), sites of CLL B-cell expansion. Activated/dividing cells upregulate a number of surface proteins that promote interactions with $\mathrm{T}$ lymphocytes. These interactions upregulate the DNA-mutating enzyme AID, which can cause mutations in genes genome-wide, leading to clonal evolution and possibly more aggressive disease. After expansion, some recently divided CLL cells exit the lymphoid tissue, entering the circulation bearing the CXCR4 ${ }^{\text {Dim }} \mathrm{CD} 5{ }^{\text {Bright }}$ phenotype ("proliferative fraction" [Calissano et al. 2011]). Over time, the circulating cells express more CXCR4 and less CD5, eventually morphing into a CXCR $4^{\text {Bright }} \mathrm{CD} 5^{\text {Dim }}$ resting fraction (RF) phenotype. These cells are best suited to follow a CXCL12/SDF1 gradient because of high levels of CXCR4, returning back to nutrient-rich niches in tissues and being rescued from apoptosis by IL-4 and likely other cytokines. Cells that cannot reenter tissues or do not arrive soon enough die. Once rescued, CLL cells proceed to a proliferation center to re-initiate the proliferative process and potential further clonal evolution or dock on a stromal element, where they again reside in the resting state. 
N. Chiorazzi et al.

NOTCH1 mutations are found in $>30 \%$ of cases (Allan and Furman 2019). A microRNA expression signature has also been identified in RT (Van Roosbroeck et al. 2018).

Therapy for Relapsed/Refractory and Accelerated Disease and for Richter's Transformation

Table 3 lists a series of therapies for patients in these categories, again based on the physical condition of the patient and the goal of treatment. For patients relapsing on ibrutinib, progression appears accelerated and less wellcontrolled (Jain et al. 2015; Maddocks et al. 2015). Leukemic cells of patients failing ibrutinib can contain mutations at the site in the Btk molecule where the drug binds (cysteine 481) or in downstream signaling molecules (Furman et al. 2014a; Woyach et al. 2014a; Cheng et al. 2015); such variants appear to be selected from cells bearing these mutations existing prior to treatment (Woyach et al. 2014a).

Outcomes for RT patients treated with chemoimmunotherapy remain dismal. Because of the ineffectiveness of chemoimmunotherapy and the dysfunction of T cells, NK cells, and other immune subsets, novel agents targeting RT cells and their interaction with immune subsets in LNs are being developed.

In a few reports, treatment with ibrutinib induced partial responses or retained stable disease in RT patients (Giri et al. 2015; Fischer et al. 2018); this could be caused by reduced proliferation of CLL/RS cells expressing AID (Reiniger et al. 2006). However, CLL patients that develop accelerated CLL or RT can progress on ibrutinib (Kadri et al. 2017); because ibrutinib is now used as front-line therapy, finding an effective therapy for this subset of patients is urgently needed. The BCL-2 inhibitor, venetoclax, alone (Jones et al. 2018) or in combination with ibrutinib (Flinn et al. 2019; Rogers 2019) may be beneficial for relapse/refractory patients and for RT (Roberts et al. 2016), although the effectiveness of these and resistance to venetoclax (Blombery et al. 2019) are evolving.

T-cell exhaustion and impaired T cell-B cell interactions promote disease progression in patients with RT. Improving T-cell function with anti-PD1 or anti-PDL1 mAb treatments (pembrolizumab or nivolumab) was therapeutic in a CLL mouse model (McClanahan et al. 2015), in patients with relapsed/refractory Hodgkin lymphoma (Ansell et al. 2015), and in patients with CLL-derived RT (Ding et al. 2015). The combination of pembrolizumab and ibrutinib in patients with RT is being evaluated (NCT20332980). Overall, BCR inhibitors and immune checkpoint inhibitors appear promising, although the number of patients treated is limited, and studies of larger patient cohorts are needed to define optimal therapeutic strategies.

An approach to enhancing actions of cytolytic T lymphocytes comes from work inserting, into the T-cell surface membrane, the antigenbinding portion of an antibody that binds $\mathrm{B}$ lymphocytes (e.g., CD19) linked to the constant and signaling regions of a T-cell receptor (Gross et al. 1989; Eshhar et al. 1993). These engineered CAR-T cells kill target cells independent of histocompatibility constraints and the requirements for antibody-dependent and complement-dependent cytotoxicty.

CAR-T therapy has had dramatic results in selected relapsed/refractory CLL patients (Brentjens et al. 2011; Porter et al. 2011), and larger studies indicate beneficial responses in $\sim 30 \%-50 \%$ of patients (Frey and Porter 2016; Romero 2017; Turtle et al. 2017). Using T cells from patients who received ibrutinib (Fraietta et al. 2016; Harper 2019) or cells expanded in the presence of PI3K $\delta$ inhibitors (Petersen et al. 2018) or the selective expansion of autologous $\mathrm{CD}^{+}{ }^{+}$and $\mathrm{CD}^{+}$cells infused at defined CD4 to CD8 ratios (Sommermeyer et al. 2016; Turtle et al. 2016) have improved effectiveness.

However, CAR-T cells can result in major complications. A cytokine release syndrome (Lee et al. 2014) from liberation of pro-inflammatory cytokines (Kochenderfer et al. 2012), including IL-6 (Lee et al. 2014), can occur. Blocking the IL-6 receptor with mAbs is helpful (Lee et al. 2014). The use of CAR-T therapy will increase as effective ways of lessening complications emerge (Acharya et al. 2019). Moreover, because CAR-Ts use anti-B-cell antibodies to 
target CLL cells, normal B lymphocytes are also eliminated, leading to hypogammaglobulinemia (Kochenderfer et al. 2010).

\section{Implications for More Effective Disease Interventions and Possible Cures}

Several avenues could lead to new therapies and hopefully cures. Considering the major beneficial impact inhibitors of BTK and PI3K signaling have had on CLL, it is likely that combinations of these drugs with newly approved agents such as venetoclax will lead to more profound, long-lasting effects and longer overall survival; several such studies are under way. Moreover, targeting other signaling pathways supporting survival and growth of CLL cells may be valuable adjuncts to current enzyme inhibitors.

As deep DNA sequencing becomes more available, rapid, and inexpensive, therapeutic decisions might take into consideration specific gene abnormalities and clonal architecture in individual patients. Personalized therapy might involve replacing/overexpressing/removing microRNAs because they can be oncogenic or tumor-inhibitory. Similarly, targeting patientspecific driver mutations and the pathways they derange, early or during disease progression, could achieve this goal.

Because of their shared features, targeting stereotyped BCRs might be feasible for discrete groups of patients. Development of small molecules reactive with stereotypes (Liu et al. 2013; Sarkar et al. 2014, 2016) and humanized mAbs binding specific IGHVs (Chang et al. 2016) support this possibility.

Finally, safer and more specific and effective CAR-T cells, and the reinfusion of functionally competent autologous $\mathrm{T}$ cells capable of recognizing CLL-specific antigens, similar to those emerging in myeloma (Thompson et al. 2003), may advance cellular therapy.

\section{REFERENCES}

Acharya UH, Dhawale T, Yun S, Jacobson CA, Chavez JC, Ramos JD, Appelbaum J, Maloney DG. 2019. Management of cytokine release syndrome and neurotoxicity in chimeric antigen receptor (CAR) T cell therapy. Expert Rev Hematol 12: 195-205. doi:10.1080/17474086.2019 .1585238

Adams JM, Cory S. 2018. The BCL-2 arbiters of apoptosis and their growing role as cancer targets. Cell Death Differ 25: 27-36. doi:10.1038/cdd.2017.161

Agathangelidis A, Darzentas N, Hadzidimitriou A, Brochet X, Murray F, Yan XJ, Davis Z, van Gastel-Mol EJ, Tresoldi C, Chu CC, et al. 2012. Stereotyped B-cell receptors in one-third of chronic lymphocytic leukemia: A molecular classification with implications for targeted therapies. Blood 119: 4467-4475. doi:10.1182/blood-2011-11393694

Agathangelidis A, Ljungström V, Scarfò L, Fazi C, Gounari M, Pandzic T, Sutton L-A, Stamatopoulos K, Tonon G, Rosenquist R, et al. 2018. Highly similar genomic landscapes in monoclonal B-cell lymphocytosis and ultra-stable chronic lymphocytic leukemia with low frequency of driver mutations. Haematologica 103: 865-873. doi:10 3324/haematol.2017.177212

Agathangelidis A, Psomopoulos F, Stamatopoulos K. 2019. Stereotyped B cell receptor immunoglobulins in B cell lymphomas. Methods Mol Biol 1956: 139-155. doi:10 1007/978-1-4939-9151-8_7

Aguilar-Hernandez MM, Blunt MD, Dobson R, Yeomans A, Thirdborough S, Larrayoz M, Smith LD, Linley A, Strefford JC, Davies A, et al. 2016. IL-4 enhances expression and function of surface IgM in CLL cells. Blood 127: 3015-3025. doi:10.1182/blood-2015-11-682906

Alavanja MC, Hofmann JN, Lynch CF, Hines CJ, Barry KH, Barker J, Buckman DW, Thomas K, Sandler DP, Hoppin JA, et al. 2014. Non-Hodgkin lymphoma risk and insecticide, fungicide and fumigant use in the agricultural health study. PLoS One 9: e109332. doi:10.1371/journal .pone.0109332

Albesiano E, Messmer BT, Damle RN, Allen SL, Rai KR, Chiorazzi N. 2003. Activation-induced cytidine deaminase in chronic lymphocytic leukemia B cells: Expression as multiple forms in a dynamic, variably sized fraction of the clone. Blood 102: 3333-3339. doi:10.1182/blood2003-05-1585

Alexandrov LB, Nik-Zainal S, Wedge DC, Aparicio SA, Behjati S, Biankin AV, Bignell GR, Bolli N, Borg A, BorresenDale AL, et al. 2013. Signatures of mutational processes in human cancer. Nature 500: 415-421. doi:10.1038/na ture 12477

Allan JN, Furman RR. 2019. Current trends in the management of Richter's syndrome. Int J Hematol Oncol 7: IJH09. doi:10.2217/ijh-2018-0010

Anderson MA, Deng J, Seymour JF, Tam C, Kim SY, Fein J, Yu L, Brown JR, Westerman D, Si EG, et al. 2016. The BCL2 selective inhibitor venetoclax induces rapid onset apoptosis of CLL cells in patients via a TP53-independent mechanism. Blood 127: 3215-3224. doi:10.1182/blood2016-01-688796

Ansell SM, Lesokhin AM, Borrello I, Halwani A, Scott EC, Gutierrez M, Schuster SJ, Millenson MM, Cattry D, Freeman GJ, et al. 2015. PD-1 blockade with nivolumab in relapsed or refractory Hodgkin's lymphoma. New Engl J Med 372: 311-319. doi:10.1056/NEJMoa1411087

Bagnara D, Callea V, Stelitano C, Morabito F, Fabris S, Neri A, Zanardi S, Ghiotto F, Ciccone E, Grossi CE, et al. 2006. 
N. Chiorazzi et al.

$\operatorname{IgV}$ gene intraclonal diversification and clonal evolution in B-cell chronic lymphocytic leukaemia. Br J Haematol 133: $50-58$.

Bagnara D, Kaufman MS, Calissano C, Marsilio S, Patten PE, Simone R, Chum P, Yan XJ, Allen SL, Kolitz JE, et al. 2011. A novel adoptive transfer model of chronic lymphocytic leukemia suggests a key role for $\mathrm{T}$ lymphocytes in the disease. Blood 117: 5463-5472. doi:10.1182/blood-201012-324210

Balogh Z, Reiniger L, Rajnai H, Csomor J, Szepesi A, Balogh A, Deak L, Gagyi E, Bodor C, Matolcsy A. 2011. High rate of neoplastic cells with genetic abnormalities in proliferation centers of chronic lymphocytic leukemia. Leuk Lymphoma 52: 1080-1084. doi:10.3109/10428194.2011 .555889

Baskar S, Kwong KY, Hofer T, Levy JM, Kennedy MG, Lee E, Staudt LM, Wilson WH, Wiestner A, Rader C. 2008. Unique cell surface expression of receptor tyrosine kinase ROR1 in human B-cell chronic lymphocytic leukemia. Clin Cancer Res 14: 396-404. doi:10.1158/1078-0432 .CCR-07-1823

Baumann Kreuziger LM, Tarchand G, Morrison VA. 2014. The impact of Agent Orange exposure on presentation and prognosis of patients with chronic lymphocytic leukemia. Leuk Lymphoma 55: 63-66. doi:10.3109/ 10428194.2013.794267

Baumann T, Delgado J, Santacruz R, Martínez-Trillos A, Rozman M, Aymerich M, López C, Costa D, Carrió A, Villamor N, et al. 2016. CD49d (ITGA4) expression is a predictor of time to first treatment in patients with chronic lymphocytic leukaemia and mutated IGHV status. $\mathrm{Br} \mathrm{J}$ Haematol 172: 48-55. doi:10.1111/bjh.13788

Beers SA, Chan CH, French RR, Cragg MS, Glennie MJ. 2010. CD20 as a target for therapeutic type I and II monoclonal antibodies. Semin Hematol 47: 107-114. doi:10 .1053 j.seminhematol.2010.01.001

Benjamini O, Jain P, Trinh L, Qiao W, Strom SS, Lerner S, Wang X, Burger J, Ferrajoli A, Kantarjian H, et al. 2015. Second cancers in patients with chronic lymphocytic leukemia who received frontline fludarabine, cyclophosphamide and rituximab therapy: Distribution and clinical outcomes. Leuk Lymphoma 56: 1643-1650. doi:10 $.3109 / 10428194.2014 .957203$

Berndt SI, Skibola CF, Joseph V, Camp NJ, Nieters A, Wang Z, Cozen W, Monnereau A, Wang SS, Kelly RS, et al. 2013. Genome-wide association study identifies multiple risk loci for chronic lymphocytic leukemia. Nat Genet 45: 868-876. doi:10.1038/ng.2652

Berndt SI, Camp NJ, Skibola CF, Vijai J, Wang Z, Gu J, Nieters A, Kelly RS, Smedby KE, Monnereau A, et al. 2016. Meta-analysis of genome-wide association studies discovers multiple loci for chronic lymphocytic leukemia. Nat Commun 7: 10933. doi:10.1038/ncomms10933

Binder M, Müller F, Jackst A, Léchenne B, Pantic M, Bacher U, Zu Eulenburg C, Veelken H, Mertelsmann R, Pasqualini R, et al. 2011. B-cell receptor epitope recognition correlates with the clinical course of chronic lymphocytic leukemia. Cancer 117: 1891-1900. doi:10.1002/cncr .25755

Binder M, Müller F, Frick M, Wehr C, Simon F, Leistler B, Veelken H, Mertelsmann R, Trepel M. 2013. CLL B-cell receptors can recognize themselves: Alternative epitopes and structural clues for autostimulatory mechanisms in CLL. Blood 121: 239-241. doi:10.1182/blood-2012-09454439

Binet JL, Auquier A, Dighiero G, Chastang C, Piguet H, Goasguen J, Vaugier G, Potron G, Colona P, Oberling F, et al. 1981. A new prognostic classification of chronic lymphocytic leukemia derived from a multivariate survival analysis. Cancer 48: 198-206.

Blombery P, Anderson MA, Gong JN, Thijssen R, Birkinshaw RW, Thompson ER, Teh CE, Nguyen T, Xu Z, Flensburg C, et al. 2019. Acquisition of the recurrent Gly101Val mutation in BCL2 confers resistance to venetoclax in patients with progressive chronic lymphocytic leukemia. Cancer Discov 9: 342-353. doi:10.1158/21598290.CD-18-1119

Bonato M, Pittaluga S, Tierens A, Criel A, Verhoef G, Wlodarska I, Vanutysel L, Michaux L, Vandekerckhove P, Van den Berghe H, et al. 1998. Lymph node histology in typical and atypical chronic lymphocytic leukemia. Am J Surg Pathol 22: 49-56. doi:10.1097/00000478199801000-00006

Borche L, Lim A, Binet JL, Dighiero G. 1990. Evidence that chronic lymphocytic leukemia B lymphocytes are frequently committed to production of natural autoantibodies. Blood 76: 562-569. doi:10.1182/blood.V76.3.562.562

Böttcher S. 2019. Flow cytometric MRD detection in selected mature B-cell malignancies. Methods Mol Biol 1956: 157197. doi:10.1007/978-1-4939-9151-8_8

Böttcher S, Ritgen M, Fischer K, Stilgenbauer S, Busch RM, Fingerle-Rowson G, Fink AM, Bühler A, Zenz T, Wenger MK, et al. 2012. Minimal residual disease quantification is an independent predictor of progression-free and overall survival in chronic lymphocytic leukemia: A multivariate analysis from the randomized GCLLSG CLL8 trial. J Clin Oncol 30: 980-988. doi:10.1200/JCO.2011.36.9348

Braggio E, Kay NE, Vanwier S, Tschumper RC, Smoley S, Eckel-Passow JE, Sassoon T, Barrett M, Van Dyke DL, Byrd JC, et al. 2012. Longitudinal genome-wide analysis of patients with chronic lymphocytic leukemia reveals complex evolution of clonal architecture at disease progression and at the time of relapse. Leukemia 26: 16981701. doi:10.1038/leu.2012.14

Brentjens RJ, Rivière I, Park JH, Davila ML, Wang X, Stefanski J, Taylor C, Yeh R, Bartido S, Borquez-Ojeda O, et al. 2011. Safety and persistence of adoptively transferred autologous CD19-targeted $\mathrm{T}$ cells in patients with relapsed or chemotherapy refractory B-cell leukemias. Blood 118: 4817-4828. doi:10.1182/blood-2011-04348540

Bröker BM, Klajman A, Youinou P, Jouquan J, Worman CP, Murphy J, Mackenzie L, Quartey-Papafio R, Blaschek M, Collins P, et al. 1988. Chronic lymphocytic leukemic (CLL) cells secrete multispecific autoantibodies. J Autoimmun 1: 469-481. doi:10.1016/0896-8411(88)90068-6

Broome HE, Rassenti LZ, Wang HY, Meyer LM, Kipps TJ. 2011. ROR1 is expressed on hematogones (non-neoplastic human B-lymphocyte precursors) and a minority of precursor-B acute lymphoblastic leukemia. Leuk Res 35: 1390-1394. doi:10.1016/j.leukres.2011.06.021

Brown J, Byrd JC, Coutre SE, Benson DM, Flinn IW, Wagner-Johnston ND, Spurgeon SE, Kahl BS, Bello C, Webb HK, et al. 2014. Idelalisib, an inhibitor of phosphatidyl- 
inositol 3-kinase p110 $\delta$, for relapsed/refractory chronic lymphocytic leukemia. Blood 123: 3390-3397. doi:10 .1182/blood-2013-11-535047

Bulian P, Gaidano G, Del Poeta G, Gattei V. 2008. CD49d expression in chronic lymphocytic leukemia: A prognostic parameter and a therapeutic target. Future Oncol 4: 355-358. doi:10.2217/14796694.4.3.355

Bulian P, Shanafelt TD, Fegan C, Zucchetto A, Cro L, Nückel H, Baldini L, Kurtova AV, Ferrajoli A, Burger JA, et al. 2014. CD49d is the strongest flow cytometry-based predictor of overall survival in chronic lymphocytic leukemia. J Clin Oncol 32: 897-904. doi:10.1200/JCO.2013.50 .8515

Burger JA, Bürkle A. 2007. The CXCR4 chemokine receptor in acute and chronic leukaemia: A marrow homing receptor and potential therapeutic target. $\mathrm{Br} J$ Haematol 137: 288-296. doi:10.1111/j.1365-2141.2007.06590.x

Burger JA, Kipps TJ. 2002. Chemokine receptors and stromal cells in the homing and homeostasis of chronic lymphocytic leukemia B cells. Leuk Lymphoma 43: 461-466. doi:10.1080/10428190290011921

Burger JA, Tsukada N, Burger M, Zvaifler NJ, Dell'Aquila M, Kipps TJ. 2000. Blood-derived nurse-like cells protect chronic lymphocytic leukemia B cells from spontaneous apoptosis through stromal cell-derived factor-1. Blood 96: 2655-2663. doi:10.1182/blood.V96.8.2655

Burger JA, Quiroga MP, Hartmann E, Bürkle A, Wierda WG, Keating MJ, Rosenwald A. 2009. High-level expression of the T-cell chemokines CCL 3 and CCL 4 by chronic lymphocytic leukemia B cells in nurselike cell cocultures and after BCR stimulation. Blood 113: 3050-3058. doi:10 .1182/blood-2008-07-170415

Burger J, O'Brien S, Fowler N, Advani R, Sharman JP, Furman RR, Izumi R, Buggy J, Loury D, Hamdy A, et al. 2010. The Bruton's tyrosine kinase inhibitor, PCI-32765, is well tolerated and demonstrates promising clinical activity in chronic lymphocytic leukemia (CLL) and small lymphocytic lymphoma (SLL): An update on ongoing phase 1 studies. Blood 116: 57. doi:10.1182/blood.V116.21.57.57 53rd ASH meeting abstract

Burger JA, Li KW, Keating MJ, Sivina M, Amer AM, Garg N, Ferrajoli A, Huang X, Kantarjian H, Wierda WG, et al. 2017. Leukemia cell proliferation and death in chronic lymphocytic leukemia patients on therapy with the BTK inhibitor ibrutinib. JCI Insight 2: e89904. doi:10.1172/jci insight.89904

Burns A, Alsolami R, Becq J, Timbs A, Bruce D, Robbe P, Vavoulis D, Cabes M, Dreau H, Taylor J, et al. 2018. Whole-genome sequencing of chronic lymphocytic leukemia reveals distinct differences in the mutational landscape between IgHV ${ }^{\text {mut }}$ and IgHV ${ }^{\text {unmut }}$ subgroups. Leukemia 32: 332-342. doi:10.1038/leu.2017.177

Byrd JC, Furman RR, Coutre SE, Flinn IW, Burger JA, Blum KA, Grant B, Sharman JP, Coleman M, Wierda WG, et al. 2013. Targeting BTK with Ibrutinib in relapsed chronic lymphocytic leukemia. New Engl J Med 369: 32-42. doi:10 .1056/NEJMoa1215637

Byrd JC, Furman RR, Coutre SE, Burger JA, Blum KA, Coleman M, Wierda WG, Jones JA, Zhao W, Heerema NA, et al. 2015. Three-year follow-up of treatment-naïve and previously treated patients with CLL and SLL receiving single-agent ibrutinib. Blood 125: 2497-2506. doi:10 .1182/blood-2014-10-606038

Caldeira D, Alves D, Costa J, Ferreira JJ, Pinto FJ. 2019. Ibrutinib increases the risk of hypertension and atrial fibrillation: Systematic review and meta-analysis. PLoS One 14: e0211228. doi:10.1371/journal.pone.0211228

Calin GA, Dumitru CD, Shimizu M, Bichi R, Zupo S, Noch E, Aldler H, Rattan S, Keating M, Rai K, et al. 2002. Nonlinear partial differential equations and applications: Frequent deletions and down-regulation of micro-RNA genes miR15 and miR16 at 13q14 in chronic lymphocytic leukemia. Proc Natl Acad Sci 99: 15524-15529. doi:10 $.1073 /$ pnas.242606799

Calissano C, Damle RN, Marsilio S, Yan XJ, Yancopoulos S, Hayes G, Emson C, Murphy EJ, Hellerstein MK, Sison C, et al. 2011. Intraclonal complexity in chronic lymphocytic leukemia: Fractions enriched in recently born/divided and older/quiescent cells. Mol Med 17: 1374-1382. doi:10.2119/molmed.2011.00360

Casabonne D, Almeida J, Nieto WG, Romero A, FernándezNavarro P, Rodriguez-Caballero A, Muñoz-Criado S, Díaz MG, Benavente Y, de Sanjosé S, et al. 2012. Common infectious agents and monoclonal B-cell lymphocytosis: A cross-sectional epidemiological study among healthy adults. PLoS One 7: e52808. doi:10.1371/journal.pone .0052808

Catera R, Hatzi K, Chu CC, Herve' M, Meffre E, Ferrarini M, Oscier D, Davis Z, Allen S, Rai K, et al. 2006. Polyreactive monoclonal antibodies synthesized by some B-CLL cells recognize specific antigens on viable and apoptotic $\mathrm{T}$ cells. Blood 108: 2813. doi:10.1182/blood.V108.11.2813 .2813

Cerutti PA. 1994. Oxy-radicals and cancer. Lancet 344: 862 863. doi:10.1016/S0140-6736(94)92832-0

Cerutti A, Zan H, Kim EC, Shah S, Schattner EJ, Schaffer A, Casali P. 2002. Ongoing in vivo immunoglobulin class switch DNA recombination in chronic lymphocytic leukemia B cells. J Immunol 169: 6594-6603. doi:10.4049/ jimmunol.169.11.6594

Chan HT, Hughes D, French RR, Tutt AL, Walshe CA, Teeling JL, Glennie MJ, Cragg MS. 2003. CD20-induced lymphoma cell death is independent of both caspases and its redistribution into triton X-100 insoluble membrane rafts. Cancer Res 63: 5480-5489.

Chang DK, Kurella VB, Biswas S, Avnir Y, Sui J, Wang X, Sun J, Wang Y, Panditrao M, Peterson E, et al. 2016. Humanized mouse G6 anti-idiotypic monoclonal antibody has therapeutic potential against IGHV1-69 germline genebased B-CLL. MAbs 8: 787-798. doi:10.1080/19420862 .2016 .1159365

Chen SS, Batliwalla F, Holodick NE, Yan XJ, Yancopoulos S, Croce CM, Rothstein TL, Chiorazzi N. 2013. Autoantigen can promote progression to a more aggressive TCL1 leukemia by selecting variants with enhanced B-cell receptor signaling. Proc Natl Acad Sci 110: E1500-E1507. doi:10 $.1073 /$ pnas. 1300616110

Chen SS, Chang BY, Chang S, Tong T, Ham S, Sherry B, Burger JA, Rai KR, Chiorazzi N. 2016. BTK inhibition results in impaired CXCR4 chemokine receptor surface expression, signaling and function in chronic lymphocytic leukemia. Leukemia 30: 833-843. doi:10.1038/leu.2015 .316 
N. Chiorazzi et al.

Cheng S, Guo A, Lu P, Ma J, Coleman M, Wang YL. 2015 Functional characterization of $B T K^{C 481 S}$ mutation that confers ibrutinib resistance: Exploration of alternative kinase inhibitors. Leukemia 29: 895-900. doi:10.1038/leu .2014 .263

Chiorazzi N. 2007. Cell proliferation and death: Forgotten features of chronic lymphocytic leukemia B cells. Best Pract Res Clin Haematol 20: 399-413. doi:10.1016/j .beha.2007.03.007

Chiorazzi N, Efremov DG. 2013. Chronic lymphocytic leukemia: A tale of one or two signals? Cell Res 23: 182-185. doi:10.1038/cr.2012.152

Chiorazzi N, Ferrarini M. 2003. B cell chronic lymphocytic leukemia: Lessons learned from studies of the B cell antigen receptor. Annu Rev Immunol 21: 841-894. doi:10 $.1146 /$ annurev.immunol.21.120601.141018

Choi MY, Widhopf GF II, Wu CC, Cui B, Lao F, Sadarangani A, Cavagnaro J, Prussak C, Carson DA, Jamieson C, et al. 2015. Pre-clinical specificity and safety of UC-961, a firstin-class monoclonal antibody targeting ROR1. Clin Lymphoma Myeloma Leuk 15(Suppl.): S167-S169. doi:10 $.1016 /$ j.clml.2015.02.010

Chu CC, Catera R, Hatzi K, Yan XJ, Zhang L, Wang XB, Fales HM, Allen SL, Kolitz JE, Rai KR, et al. 2008. Chronic lymphocytic leukemia antibodies with a common stereotypic rearrangement recognize nonmuscle myosin heavy chain IIA. Blood 112: 5122-5129. doi:10.1182/blood2008-06-162024

Chu CC, Catera R, Zhang L, Didier S, Agagnina BM, Damle RN, Kaufman MS, Kolitz JE, Allen SL, Rai KR, et al. 2010. Many chronic lymphocytic leukemia antibodies recognize apoptotic cells with exposed nonmuscle myosin heavy chain IIA: Implications for patient outcome and cell of origin. Blood 115: 3907-3915. doi:10.1182/blood2009-09-244251

Chumak VV, Romanenko AY, Voillequé PG, Bakhanova EV, Gudzenko N, Hatch M, Zablotska LB, Golovanov IA, Luckyanov NK, Sholom SV, et al. 2008. The UkrainianAmerican study of leukemia and related disorders among chornobyl cleanup workers from Ukraine: II. Estimation of bone marrow doses. Radiat Res 170: 698-710. doi:10 $.1667 / R R 1403.1$

Cimmino A, Calin GA, Fabbri M, Iorio MV, Ferracin M, Shimizu M, Wojcik SE, Aqeilan RI, Zupo S, Dono M, et al. 2005. $m i R-15$ and $m i R-16$ induce apoptosis by targeting BCL2. Proc Natl Acad Sci 102: 13944-13949. doi:10 $.1073 /$ pnas.0506654102

Coggon D, Ntani G, Harris EC, Jayakody N, Palmer KT. 2015. Soft tissue sarcoma, non-Hodgkin's lymphoma and chronic lymphocytic leukaemia in workers exposed to phenoxy herbicides: Extended follow-up of a UK cohort. Occup Environ Med 72: 435-441. doi:10.1136/ oemed-2014-102654

Condoluci A, Rossi D. 2017. Treatment of Richter's syndrome. Curr Treat Options Oncol 18: 75. doi:10.1007/ s11864-017-0512-y

Cragg MS, Morgan SM, Chan HT, Morgan BP, Filatov AV, Johnson PW, French RR, Glennie MJ. 2003. Complement-mediated lysis by anti-CD20 mAb correlates with segregation into lipid rafts. Blood 101: 1045-1052. doi:10 $.1182 /$ blood-2002-06-1761
Crespo M, Bosch F, Villamor N, Bellosillo B, Colomer D, Rozman M, Marcé S, López-Guillermo A, Campo E, Montserrat E. 2003. ZAP-70 expression as a surrogate for immunoglobulin-variable-region mutations in chronic lymphocytic leukemia. N Engl J Med 348: 1764-1775. doi:10.1056/NEJMoa023143

Crowther-Swanepoel D, Broderick P, Di Bernardo MC, Dobbins SE, Torres M, Mansouri M, Ruiz-Ponte C, Enjuanes A, Rosenquist R, Carracedo A, et al. 2010a. Common variants at $2 \mathrm{q} 37.3,8 \mathrm{q} 24.21,15 \mathrm{q} 21.3$ and $16 \mathrm{q} 24.1$ influence chronic lymphocytic leukemia risk. Nat Genet 42: 132-136. doi:10.1038/ng.510

Crowther-Swanepoel D, Corre T, Lloyd A, Gaidano G, Olver B, Bennett FL, Doughty C, Toniolo D, Caligaris-Cappio F, Ghia P, et al. 2010b. Inherited genetic susceptibility to monoclonal B-cell lymphocytosis. Blood 116: 59575960. doi:10.1182/blood-2010-07-294975

Cui B, Ghia EM, Chen L, Rassenti LZ, DeBoever C, Widhopf GF, Yu J, Neuberg DS, Wierda WG, Rai KR, et al. 2016. High-level ROR1 associates with accelerated disease progression in chronic lymphocytic leukemia. Blood 128: 2931-2940. doi:10.1182/blood-2016-04-712562

Damle RN, Wasil T, Fais F, Ghiotto F, Valetto A, Allen SL, Buchbinder A, Budman D, Dittmar K, Kolitz J, et al. 1999. Ig V gene mutation status and CD38 expression as novel prognostic indicators in chronic lymphocytic leukemia. Blood 94: 1840-1847. doi:10.1182/blood.V94.6.1840

Damle RN, Ghiotto F, Valetto A, Albesiano E, Fais F, Yan XJ, Sison CP, Allen SL, Kolitz J, Schulman P, et al. 2002. B-cell chronic lymphocytic leukemia cells express a surface membrane phenotype of activated, antigen-experienced B lymphocytes. Blood 99: 4087-4093. doi:10.1182/blood V99.11.4087

Damle RN, Batliwalla FM, Ghiotto F, Valetto A, Albesiano E, Sison C, Allen SL, Kolitz J, Vinciguerra VP, Kudalkar P, et al. 2004. Telomere length and telomerase activity delineate distinctive replicative features of the B-CLL subgroups defined by immunoglobulin $\mathrm{V}$ gene mutations. Blood 103: 375-382. doi:10.1182/blood-2003-04-1345

Damm F, Mylonas E, Cosson A, Yoshida K, Della Valle V, Mouly E, Diop M, Scourzic L, Shiraishi Y, Chiba K, et al. 2014. Acquired initiating mutations in early hematopoietic cells of CLL patients. Cancer Discov 4: 1088-1101. doi:10.1158/2159-8290.CD-14-0104

Daneshmanesh AH, Mikaelsson E, Jeddi-Tehrani M, Bayat AA, Ghods R, Ostadkarampour M, Akhondi M, Lagercrantz S, Larsson C, Osterborg A, et al. 2008. Ror1, a cell surface receptor tyrosine kinase is expressed in chronic lymphocytic leukemia and may serve as a putative target for therapy. Int J Cancer 123: 1190-1195. doi:10.1002/ijc .23587

Deaglio S, Dianzani U, Horenstein AL, Fernandez JE, van Kooten C, Bragardo M, Funaro A, Garbarino G, Di Virgilio F, Banchereau J, et al. 1996. Human CD38 ligand. A $120-$ KDA protein predominantly expressed on endothelial cells. J Immunol 156: 727-734.

Deaglio S, Mallone R, Baj G, Arnulfo A, Surico N, Dianzani U, Mehta K, Malavasi F. 2000. CD38/CD31, a receptor/ ligand system ruling adhesion and signaling in human leukocytes. Chem Immunol 75: 99-120. doi:10.1159/ 000058765 
Deaglio S, Capobianco A, Bergui L, Dürig J, Morabito F, Dührsen U, Malavasi F. 2003. CD38 is a signaling molecule in B-cell chronic lymphocytic leukemia cells. Blood 102: 2146-2155. doi:10.1182/blood-2003-03-0989

Deaglio S, Vaisitti T, Aydin S, Bergui L, D’Arena G, Bonello L, Omede P, Scatolini M, Jaksic O, Chiorino G, et al. 2007. CD38 and ZAP-70 are functionally linked and mark CLL cells with high migratory potential. Blood 110: 40124021. doi:10.1182/blood-2007-06-094029

Defoiche J, Debacq C, Asquith B, Zhang Y, Burny A, Bron D, Lagneaux L, Macallan D, Willems L. 2008. Reduction of B cell turnover in chronic lymphocytic leukaemia. $\mathrm{Br} \mathrm{J}$ Haematol 143: 240-247. doi:10.1111/j.1365-2141.2008 .07348.x

de Gorter DJJ, Beuling EA, Kersseboom R, Middendorp S, van Gils JM, Hendriks RW, Pals ST, Spaargaren M. 2007. Bruton's tyrosine kinase and phospholipase $\mathrm{C} \gamma 2$ mediate chemokine-controlled B cell migration and homing. Immunity 26: 93-104. doi:10.1016/j.immuni.2006.11.012

Delgado J, Doubek M, Baumann T, Kotaskova J, Molica S, Mozas P, Rivas-Delgado A, Morabito F, Pospisilova S, Montserrat E. 2017. Chronic lymphocytic leukemia: A prognostic model comprising only two biomarkers (IGHV mutational status and FISH cytogenetics) separates patients with different outcome and simplifies the CLL-IPI. Am J Hematol 92: 375-380. doi:10.1002/ajh .24660

de Rooij MF, Kuil A, Geest CR, Eldering E, Chang BY, Buggy JJ, Pals ST, Spaargaren M. 2012. The clinically active BTK inhibitor PCI-32765 targets B-cell receptor- and chemokine-controlled adhesion and migration in chronic lymphocytic leukemia. Blood 119: 2590-2594. doi:10.1182/ blood-2011-11-390989

de Weerdt I, Koopmans SM, Kater AP, van Gelder M. 2017. Incidence and management of toxicity associated with ibrutinib and idelalisib: A practical approach. Haematologica 102: 1629-1639. doi:10.3324/haematol.2017 .164103

Di Bernardo MC, Crowther-Swanepoel D, Broderick P, Webb E, Sellick G, Wild R, Sullivan K, Vijayakrishnan J, Wang Y, Pittman AM, et al. 2008. A genome-wide association study identifies six susceptibility loci for chronic lymphocytic leukemia. Nat Genet 40: 1204-1210. doi:10 .1038/ng.219

Di Giovanni S, Valentini G, Carducci P, Giallonardo P. 1989. $\beta$-2-microglobulin is a reliable tumor marker in chronic lymphocytic leukemia. Acta Haematol 81: 181-185. doi:10.1159/000205558

Dimier N, Delmar P, Ward C, Morariu-Zamfir R, FingerleRowson G, Bahlo J, Fischer K, Eichhorst B, Goede V, van Dongen JJM, et al. 2018. A model for predicting effect of treatment on progression-free survival using MRD as a surrogate end point in CLL. Blood 131: 955-962. doi:10 .1182/blood-2017-06-792333

Ding W, Dong H, Call TG, Shanafelt TD, Parikh SA, Leis JF, Laplant BR, He R, Witzig TE, Lin Y, et al. 2015. PD-1 blockade with pembrolizumab (MK-3475) in relapsed/ refractory CLL including Richter transformation: An early efficacy report from a phase 2 trial (MC1485). Blood 126: 834. doi:10.1182/blood.V126.23.834.834

Döhner H, Stilgenbauer S, Benner A, Leupolt E, Kröber A, Bullinger L, Döhner K, Bentz M, Lichter P. 2000. Geno- mic aberrations and survival in chronic lymphocytic leukemia. N Engl J Med 343: 1910-1916. doi:10.1056/ NEJM200012283432602

Dühren-von Minden M, Übelhart R, Schneider D, Wossning T, Bach MP, Buchner M, Hofmann D, Surova E, Follo M, Köhler F, et al. 2012. Chronic lymphocytic leukaemia is driven by antigen-independent cell-autonomous signalling. Nature 489: 309-312. doi:10.1038/nature11309

Eschbach C, Bach MP, Fidler I, Pelanda R, Köhler F, Rajewsky K, Jumaa H. 2011. Efficient generation of B lymphocytes by recognition of self-antigens. Eur J Immunol 41: 2397-2403. doi:10.1002/eji.201041344

Eshhar Z, Waks T, Gross G, Schindler DG. 1993. Specific activation and targeting of cytotoxic lymphocytes through chimeric single chains consisting of antibodybinding domains and the $\gamma$ or $\zeta$ subunits of the immunoglobulin and T-cell receptors. Proc Natl Acad Sci 90: 720724. doi:10.1073/pnas.90.2.720

Fabbri G, Rasi S, Rossi D, Trifonov V, Khiabanian H, Ma J, Grunn A, Fangazio M, Capello D, Monti S, et al. 2011. Analysis of the chronic lymphocytic leukemia coding genome: Role of NOTCH1 mutational activation. J Exp Med 208: 1389-1401. doi:10.1084/jem.20110921

Fabbri G, Khiabanian H, Holmes AB, Wang J, Messina M, Mullighan CG, Pasqualucci L, Rabadan R, Dalla-Favera R. 2013. Genetic lesions associated with chronic lymphocytic leukemia transformation to Richter syndrome. J Exp Med 210: 2273-2288. doi:10.1084/jem.20131448

Fais F, Ghiotto F, Hashimoto S, Sellars B, Valetto A, Allen SL, Schulman P, Vinciguerra VP, Rai K, Rassenti LZ, et al. 1998. Chronic lymphocytic leukemia B cells express restricted sets of mutated and unmutated antigen receptors. J Clin Invest 102: 1515-1525. doi:10.1172/JCI3009

Falchi L, Vitale C, Keating MJ, Lerner S, Wang X, Elhor Gbito KY, Strom S, Wierda WG, Ferrajoli A. 2016. Incidence and prognostic impact of other cancers in a population of long-term survivors of chronic lymphocytic leukemia. Ann Oncol 27: 1100-1106. doi:10.1093/ann onc/mdw072

Farooqui MZ, Valdez J, Martyr S, Aue G, Saba N, Niemann CU, Herman SE, Tian X, Marti G, Soto S, et al. 2015. Ibrutinib for previously untreated and relapsed or refractory chronic lymphocytic leukaemia with TP53 aberrations: A phase 2, single-arm trial. Lancet Oncol 16: 169-176. doi:10.1016/S1470-2045(14)71182-9

Finn WG, Kay NE, Kroft SH, Church S, Peterson LC. 1998. Secondary abnormalities of chromosome $6 \mathrm{q}$ in B-cell chronic lymphocytic leukemia: A sequential study of karyotypic instability in 51 patients. Am J Hematol 59: 223229. doi:10.1002/(SICI)1096-8652(199811)59:3<223:: AID-AJH7>3.0.CO;2-Y

Fiorcari S, Brown WS, McIntyre BW, Estrov Z, Maffei R, O'Brien S, Sivina M, Hoellenriegel J, Wierda WG, Keating MJ, et al. 2013. The PI3-kinase $\delta$ inhibitor idelalisib (GS1101) targets integrin-mediated adhesion of chronic lymphocytic leukemia (CLL) cell to endothelial and marrow stromal cells. PLoS One 8: e83830. doi:10.1371/journal .pone. 0083830

Fischer K, Bahlo J, Fink AM, Goede V, Herling CD, Cramer P, Langerbeins P, von Tresckow J, Engelke A, Maurer C, et al. 2016. Long-term remissions after FCR chemoimmunotherapy in previously untreated patients with CLL: Up- 
N. Chiorazzi et al.

dated results of the CLL8 trial. Blood 127: 208-215. doi:10 .1182/blood-2015-06-651125

Fischer A, Bastian S, Cogliatti S, Mey U, Saub J, Schanz U, Padberg B, Hohloch K. 2018. Ibrutinib-induced rapid response in chemotherapy-refractory Richter's syndrome. Hematol Oncol 36: 370-371. doi:10.1002/hon .2464

Flinn IW, Hillmen P, Montillo M, Nagy Z, Illés Á, Etienne G, Delgado J, Kuss BJ, Tam CS, Gasztonyi Z, et al. 2018. The phase 3 DUO trial: Duvelisib vs ofatumumab in relapsed and refractory CLL/SLL. Blood 132: 2446-2455. doi:10 .1182/blood-2018-05-850461

Flinn IW, Gribben JG, Dyer MJS, Wierda W, Maris MB, Furman RR, Hillmen P, Rogers KA, Padmanabhan Iyer S, Quillet-Mary A, et al. 2019. Phase 1b study of venetoclax-obinutuzumab in previously untreated and relapsed/ refractory chronic lymphocytic leukemia. Blood 133: 2765-2775. doi:10.1182/blood-2019-01-896290

Fong S, Chen PP, Gilbertson TA, Fox RI, Vaughan JH, Carson DA. 1985. Structural similarities in the $\kappa$ light chains of human rheumatoid factor paraproteins and serum immunoglobulins bearing a cross-reactive idiotype. J Immunol 135: 1955-1960.

Fraietta JA, Beckwith KA, Patel PR, Ruella M, Zheng Z, Barrett DM, Lacey SF, Melenhorst JJ, McGettigan SE, Cook DR, et al. 2016. Ibrutinib enhances chimeric antigen receptor T-cell engraftment and efficacy in leukemia. Blood 127: 1117-1127. doi:10.1182/blood-2015-11679134

Frey NV, Porter DL. 2016. CAR T-cells merge into the fast lane of cancer care. Am J Hematol 91: 146-150. doi:10 $.1002 / a j h .24238$

Friedman DF, Moore JS, Erikson J, Manz J, Goldman J, Nowell PC, Silberstein LE. 1992. Variable region gene analysis of an isotype-switched ( $\operatorname{IgA})$ variant of chronic lymphocytic leukemia. Blood 80: 2287-2297. doi:10 .1182/blood.V80.9.2287.2287

Fukuda T, Chen L, Endo T, Tang L, Lu D, Castro JE, Widhopf GF II, Rassenti LZ, Cantwell MJ, Prussak CE, et al. 2008 Antisera induced by infusions of autologous Ad-CD154leukemia B cells identify ROR1 as an oncofetal antigen and receptor for Wnt5a. Proc Natl Acad Sci 105: 30473052. doi:10.1073/pnas.0712148105

Fung SS, Hillier KL, Leger CS, Sandhu I, Vickars LM, Galbraith PF, Li CH, Leitch HA. 2007. Clinical progression and outcome of patients with monoclonal B-cell lymphocytosis. Leuk Lymphoma 48: 1087-1091. doi:10.1080/ 10428190701321277

Furman RR, Cheng S, Lu P, Setty M, Perez AR, Guo A Racchumi J, Xu G, Wu H, Ma J, et al. 2014a. Ibrutinib resistance in chronic lymphocytic leukemia. New Engl J Med 370: 2352-2354. doi:10.1056/NEJMc1402716

Furman RR, Sharman JP, Coutre SE, Cheson BD, Pagel JM, Hillmen P, Barrientos JC, Zelenetz AD, Kipps TJ, Flinn I, et al. 2014b. Idelalisib and rituximab in relapsed chronic lymphocytic leukemia. New Engl J Med 370: 997-1007. doi:10.1056/NEJMoa1315226

Gale RP, Cozen W, Goodman MT, Wang FF, Bernstein L. 2000. Decreased chronic lymphocytic leukemia incidence in Asians in Los Angeles county. Leuk Res 24: 665-669. doi:10.1016/S0145-2126(00)00038-2
Galletti G, Scielzo C, Barbaglio F, Rodriguez TV, Riba M, Lazarevic D, Cittaro D, Simonetti G, Ranghetti P, Scarfo L, et al. 2016. Targeting macrophages sensitizes chronic lymphocytic leukemia to apoptosis and inhibits disease progression. Cell Rep 14: 1748-1760. doi:10.1016/j.celrep .2016.01.042

Gattei V, Bulian P, Del Principe MI, Zucchetto A, Maurillo L, Buccisano F, Bomben R, Dal-Bo M, Luciano F, Rossi FM et al. 2008. Relevance of CD49d protein expression as overall survival and progressive disease prognosticator in chronic lymphocytic leukemia. Blood 111: 865-873. doi:10.1182/blood-2007-05-092486

Georgiadis P, Liampa I, Hebels DG, Krauskopf J, Chatziioannou A, Valavanis I, de Kok TMCM, Kleinjans JCS, Bergdahl IA, Melin B, et al. 2017. Evolving DNA methylation and gene expression markers of B-cell chronic lymphocytic leukemia are present in pre-diagnostic blood samples more than 10 years prior to diagnosis. BMC Genomics 18: 728. doi:10.1186/s12864-017-4117-4

Ghia P, Prato G, Scielzo C, Stella S, Geuna M, Guida G, Caligaris-Cappio F. 2004. Monoclonal $\mathrm{CD}^{+}$and $\mathrm{CD} 5$ $\mathrm{B}$-lymphocyte expansions are frequent in the peripheral blood of the elderly. Blood 103: 2337-2342. doi:10.1182/ blood-2003-09-3277

Ghiotto F, Fais F, Valetto A, Albesiano E, Hashimoto S, Dono M, Ikematsu H, Allen SL, Kolitz J, Rai KR, et al. 2004. Remarkably similar antigen receptors among a subset of patients with chronic lymphocytic leukemia. J Clin Invest 113: 1008-1016. doi:10.1172/JCI19399

Ghiotto F, Fais F, Albesiano E, Sison C, Valetto A, Gaidano G, Reinhardt J, Kolitz JE, Rai K, Allen SL, et al. 2006. Similarities and differences between the light and heavy chain Ig variable region gene repertoires in chronic lymphocytic leukemia. Mol Med 12: 300-308. doi:10.2119/ 2006-00080.Ghiotto

Ghosn EE, Sadate-Ngatchou P, Yang Y, Herzenberg LA. 2011. Distinct progenitors for B-1 and B-2 cells are present in adult mouse spleen. Proc Natl Acad Sci 108: 28792884. doi:10.1073/pnas.1019764108

Gine E, Martinez A, Villamor N, Lopez-Guillermo A, Camos M, Martinez D, Esteve J, Calvo X, Muntanola A, Abrisqueta $P$, et al. 2010. Expanded and highly active proliferation centers identify a histological subtype of chronic lymphocytic leukemia ("accelerated" chronic lymphocytic leukemia) with aggressive clinical behavior. Haematologica 95: 1526-1533. doi:10.3324/haematol.2010.022277

Giri S, Hahn A, Yaghmour G, Martin MG. 2015. Ibrutinib has some activity in Richter's syndrome. Blood Cancer J 5: e277. doi:10.1038/bcj.2014.98

Glancy E, Siles R. 2016. Monoclonal B-cell lymphocytosis and hypogammaglobulinaemia. Br J Haematol 173: $316-$ 317. doi:10.1111/bjh.13585

Gluzman D, Imamura N, Sklyarenko L, Nadgornaya V, Zavelevich M, Machilo V. 2006. Patterns of hematological malignancies in Chernobyl clean-up workers (19962005). Exp Oncol 28: 60-63.

Göckeritz E, Kerwien S, Baumann M, Wigger M, Vondey V, Neumann L, Landwehr T, Wendtner CM, Klein C, Liu N, et al. 2015. Efficacy of phosphatidylinositol-3 kinase inhibitors with diverse isoform selectivity profiles for inhibiting the survival of chronic lymphocytic leukemia cells. Int J Cancer 137: 2234-2242. doi:10.1002/ijc.29579 
Goede V, Fischer K, Busch R, Engelke A, Eichhorst B, Wendtner CM, Chagorova T, de la Serna J, Dilhuydy MS, Illmer T, et al. 2014. Obinutuzumab plus chlorambucil in patients with CLL and coexisting conditions. $N$ Engl J Med 370: 1101-1110. doi:10.1056/NEJ Moa1313984

Goldin LR, Pfeiffer RM, Li X, Hemminki K. 2004. Familial risk of lymphoproliferative tumors in families of patients with chronic lymphocytic leukemia: Results from the Swedish family-cancer database. Blood 104: 1850-1854. doi:10.1182/blood-2004-01-0341

Goldin LR, Landgren O, Marti GE, Caporaso NE. 2010. Familial aspects of chronic lymphocytic leukemia, monoclonal B-cell lymphocytosis (MBL), and related lymphomas. European J Clin Med Oncol 2: 119-126.

Gonzalez D, Martinez P, Wade R, Hockley S, Oscier D, Matutes E, Dearden CE, Richards SM, Catovsky D, Morgan GJ. 2011. Mutational status of the TP53 gene as a predictor of response and survival in patients with chronic lymphocytic leukemia: Results from the LRF CLL4 trial. J Clin Oncol 29: 2223-2229. doi:10.1200/JCO.2010.32.0838

Gounari M, Ntoufa S, Appolino B, Papakonstantinou N, Chu C, Rossi D, Gaidano G, Chiorazzi N, Stamatopoulos K, Ghia P. 2015. Excessive antigen reactivity may underlie the clinical aggressiveness of chronic lymphocytic leukemia stereotyped subset \#8. Blood 125: 3580-3587. doi:10 .1182/blood-2014-09-603217

Granziero L, Ghia P, Circosta P, Gottardi D, Strola G, Geuna M, Montagna L, Piccoli P, Chilosi M, Caligaris-Cappio F. 2001. Survivin is expressed on CD40 stimulation and interfaces proliferation and apoptosis in B-cell chronic lymphocytic leukemia. Blood 97: 2777-2783. doi:10.1182/ blood.V97.9.2777

Greco M, Capello D, Bruscaggin A, Spina V, Rasi S, Monti S, Ciardullo C, Cresta S, Fangazio M, Gaidano G, et al. 2013. Analysis of SF3B1 mutations in monoclonal B-cell lymphocytosis. Hematol Oncol 31: 54-55. doi:10.1002/hon .2013

Griffin DO, Holodick NE, Rothstein TL. 2011. Human B1 cells in umbilical cord and adult peripheral blood express the novel phenotype $\mathrm{CD} 20^{+} \mathrm{CD} 27^{+} \mathrm{CD} 43^{+} \mathrm{CD} 70^{-}$. J Exp Med 208: 67-80. doi:10.1084/jem.20101499

Gross G, Waks T, Eshhar Z. 1989. Expression of immunoglobulin-T-cell receptor chimeric molecules as functional receptors with antibody-type specificity. Proc Natl Acad Sci 86: 10024-10028. doi:10.1073/pnas.86.24.10024

Guièze R, Wu CJ. 2015. Genomic and epigenomic heterogeneity in chronic lymphocytic leukemia. Blood 126: 445-453. doi:10.1182/blood-2015-02-585042

Guo B, Zhang L, Chiorazzi N, Rothstein TL. 2016. IL-4 rescues surface IgM expression in chronic lymphocytic leukemia. Blood 128: 553-562. doi:10.1182/blood-201511-682997

Gurrieri C, McGuire P, Zan H, Yan XJ, Cerutti A, Albesiano E, Allen SL, Vinciguerra V, Rai KR, Ferrarini M, et al. 2002. Chronic lymphocytic leukemia B cells can undergo somatic hypermutation and intraclonal immunoglobulin $\mathrm{V}_{\mathrm{H}} \mathrm{DJ}_{\mathrm{H}}$ gene diversification. J Exp Med 196: 629-639. doi:10.1084/jem.20011693

Hadzidimitriou A, Darzentas N, Murray F, Smilevska T, Arvaniti E, Tresoldi C, Tsaftaris A, Laoutaris N, Anagnostopoulos A, Davi F, et al. 2009. Evidence for the significant role of immunoglobulin light chains in antigen recognition and selection in chronic lymphocytic leukemia. Blood 113: 403-411. doi:10.1182/blood-2008-07-166868

Haferlach C, Dicker F, Schnittger S, Kern W, Haferlach T. 2007. Comprehensive genetic characterization of CLL: A study on 506 cases analysed with chromosome banding analysis, interphase FISH, IgVH status and immunophenotyping. Leukemia 21: 2442-2451. doi:10.1038/sj.leu .2404935

Hallek M, Langenmayer I, Nerl C, Knauf W, Dietzfelbinger H, Adorf D, Ostwald M, Busch R, Kuhn-Hallek I, Thiel E, et al. 1999. Elevated serum thymidine kinase levels identify a subgroup at high risk of disease progression in early, nonsmoldering chronic lymphocytic leukemia. Blood 93: 1732-1737.

Hallek M, Fischer K, Fingerle-Rowson G, Fink AM, Busch R, Mayer J, Hensel M, Hopfinger G, Hess G, von Grünhagen $\mathrm{U}$, et al. 2010. Addition of rituximab to fludarabine and cyclophosphamide in patients with chronic lymphocytic leukaemia: A randomised, open-label, phase 3 trial. The Lancet 376: 1164-1174. doi:10.1016/S0140-6736(10) 61381-5

Hallek M, Cheson BD, Catovsky D, Caligaris-Cappio F, Dighiero G, Döhner H, Hillmen P, Keating M, Montserrat E, Chiorazzi N, et al. 2018. iwCLL guidelines for diagnosis, indications for treatment, response assessment, and supportive management of CLL. Blood 131: 2745-2760. doi:10.1182/blood-2017-09-806398

Hamblin TJ, Davis Z, Gardiner A, Oscier DG, Stevenson FK. 1999. Unmutated Ig $V_{H}$ genes are associated with a more aggressive form of chronic lymphocytic leukemia. Blood 94: 1848-1854. doi:10.1182/blood.V94.6.1848

Hanna BS, McClanahan F, Yazdanparast H, Zaborsky N, Kalter V, Rößner PM, Benner A, Durr C, Egle A, Gribben JG, et al. 2016. Depletion of CLL-associated patrolling monocytes and macrophages controls disease development and repairs immune dysfunction in vivo. Leukemia 30: 570-579. doi:10.1038/leu.2015.305

Harper K. 2019. Ibrutinib may boost efficacy of CAR T cells. Cancer Discov 9: OF3.

Hasan K, Yu J, Chen L, Cui B, Widhopf GF, Rassenti L, Shen Z, Briggs SP, Kipps TJ. 2017. Wnt5a induces ROR1 to complex with HS1 to enhance migration of chronic lymphocytic leukemia cells. Leukemia 31: 2615-2622. doi:10 $.1038 /$ leu.2017

Hasan MK, Rassenti L, Widhopf GF, Yu J, Kipps TJ. 2019. Wnt5a causes ROR1 to complex and activate cortactin to enhance migration of chronic lymphocytic leukemia cells. Leukemia 33: 653-661. doi:10.1038/s41375-018-0306-7

Hashimoto S, Dono M, Wakai M, Allen SL, Lichtman SM, Schulman P, Vinciguerra VP, Ferrarini M, Silver J, Chiorazzi N. 1995. Somatic diversification and selection of immunoglobulin heavy and light chain variable region genes in $\mathrm{IgG}^{+} \mathrm{CD}^{+}$chronic lymphocytic leukemia B cells. J Exp Med 181: 1507-1517. doi:10.1084/jem.181.4.1507

Hatzi K, Catera R, Moreno Atanasio C, Fischetti VA, Allen SL, Kolitz JE, Rai KR, Chu CC, Chiorazzi N. 2016. Chronic lymphocytic leukemia immunoglobulins display bacterial reactivity that converges and diverges from auto- $/$ poly-reactivity and IGHV mutation status. Clin Immunol 172: 44-51. doi:10.1016/j.clim.2016.08.020 
N. Chiorazzi et al.

Haughton G, Arnold LW, Whitmore AC, Clarke SH. 1993. B-1 cells are made, not born. Immunol Today 14: 84-87. discussion 87-91. doi:10.1016/0167-5699(93)90064-R

Hayakawa K, Hardy RR, Parks DR, Herzenberg LA. 1983. The "Ly-1 B" cell subpopulation in normal immunodefective, and autoimmune mice. J Exp Med 157: 202-218. doi:10.1084/jem.157.1.202

Hayakawa K, Formica AM, Colombo MJ, Shinton SA, BrillDashoff J, Morse Iii HC, Li YS, Hardy RR. 2016. Loss of a chromosomal region with synteny to human 13q14 occurs in mouse chronic lymphocytic leukemia that originates from early-generated B-1 B cells. Leukemia 30: 1510-1519. doi:10.1038/leu.2016.61

Herishanu Y, Pérez-Galán P, Liu D, Biancotto A, Pittaluga S, Vire B, Gibellini F, Njuguna N, Lee E, Stennett L, et al 2011. The lymph node microenvironment promotes Bcell receptor signaling, NF- $\kappa \mathrm{B}$ activation, and tumor proliferation in chronic lymphocytic leukemia. Blood 117: 563-574. doi:10.1182/blood-2010-05-284984

Herman SE, Gordon AL, Hertlein E, Ramanunni A, Zhang $\mathrm{X}$, Jaglowski S, Flynn J, Jones J, Blum KA, Buggy JJ, et al. 2011. Bruton tyrosine kinase represents a promising therapeutic target for treatment of chronic lymphocytic leukemia and is effectively targeted by PCI-32765. Blood 117: 6287-6296. doi:10.1182/blood-2011-01-328484

Herman SEM, Mustafa RZ, Gyamfi JA, Pittaluga S, Chang S, Chang B, Farooqui M, Wiestner A. 2014a. Ibrutinib inhibits B-cell receptor and NF- $\kappa \mathrm{B}$ signaling and reduces tumor proliferation in tissue-resident cells of patients with chronic lymphocytic leukemia. Blood 123: 32863295. doi:10.1182/blood-2014-02-548610

Herman SEM, Niemann CU, Farooqui M, Jones J, Mustafa RZ, Lipsky A, Saba N, Martyr S, Soto S, Valdez J, et al. 2014b. Ibrutinib-induced lymphocytosis in patients with chronic lymphocytic leukemia: Correlative analyses from a phase II study. Leukemia 28: 2188-2196. doi:10.1038/ leu.2014.122

Herman SEM, Mustafa RZ, Jones J, Wong DH, Farooqui M, Wiestner A. 2015. Treatment with ibrutinib inhibits BTKand VLA-4-dependent adhesion of chronic lymphocytic leukemia cells in vivo. Clin Cancer Res 21: 4642-4651. doi:10.1158/1078-0432.CCR-15-0781

Herndon TM, Chen SS, Saba NS, Valdez J, Emson C, Gatmaitan M, Tian X, Hughes TE, Sun C, Arthur DC, et al. 2017. Direct in vivo evidence for increased proliferation of CLL cells in lymph nodes compared to bone marrow and peripheral blood. Leukemia 31: 1340-1347. doi:10.1038/ leu.2017.11

Hervé M, Xu K, Ng YS, Wardemann H, Albesiano E, Messmer BT, Chiorazzi N, Meffre E. 2005. Unmutated and mutated chronic lymphocytic leukemias derive from self-reactive $B$ cell precursors despite expressing different antibody reactivity. J Clin Invest 115: 1636-1643. doi:10.1172/JCI24387

Hojjat-Farsangi M, Khan AS, Daneshmanesh AH, Moshfegh A, Sandin A, Mansouri L, Palma M, Lundin J, Osterborg A, Mellstedt H. 2013. The tyrosine kinase receptor ROR1 is constitutively phosphorylated in chronic lymphocytic leukemia (CLL) cells. PLoS One 8: e78339. doi:10.1371/journal.pone.0078339

Honigberg LA, Smith AM, Sirisawad M, Verner E, Loury D, Chang B, Li S, Pan Z, Thamm DH, Miller RA, et al. 2010.
The Bruton tyrosine kinase inhibitor PCI-32765 blocks B-cell activation and is efficacious in models of autoimmune disease and B-cell malignancy. Proc Natl Acad Sci 107: 13075-13080. doi:10.1073/pnas.1004594107

Hoogeboom R, van Kessel KP, Hochstenbach F, Wormhoudt TA, Reinten RJ, Wagner K, Kater AP, Guikema JE, Bende RJ, van Noesel CJ. 2013. A mutated B cell chronic lymphocytic leukemia subset that recognizes and responds to fungi. J Exp Med 210: 59-70. doi:10.1084/jem.20121801

Hudecek M, Schmitt TM, Baskar S, Lupo-Stanghellini MT, Nishida T, Yamamoto TN, Bleakley M, Turtle CJ, Chang WC, Greisman HA, et al. 2010. The B-cell tumor-associated antigen ROR1 can be targeted with T cells modified to express a ROR1-specific chimeric antigen receptor. Blood 116: 4532-4541. doi:10.1182/blood-2010-05283309

Iacovelli S, Hug E, Bennardo S, Duehren-von Minden M, Gobessi S, Rinaldi A, Suljagic M, Bilbao D, Bolasco G, Eckl-Dorna J, et al. 2015. Two types of BCR interactions are positively selected during leukemia development in the E $\mu$-TCL1 transgenic mouse model of CLL. Blood 125: 1578-1588. doi:10.1182/blood-2014-07-587790

Jain P, Young KH. 2014. Haematological cancer: Richter's transformation in CLL-A distinct lymphoma. Nat Rev Clin Oncol 11: 6-8. doi:10.1038/nrclinonc.2013.229

Jain P, Keating M, Wierda W, Estrov Z, Ferrajoli A, Jain N, George B, James D, Kantarjian H, Burger J, et al. 2015. Outcomes of patients with chronic lymphocytic leukemia after discontinuing ibrutinib. Blood 125: 2062-2067. doi:10.1182/blood-2014-09-603670

Johnson TA, Rassenti LZ, Kipps TJ. 1997. Ig VH1 genes expressed in B cell chronic lymphocytic leukemia exhibit distinctive molecular features. J Immunol 158: 235-246.

Jones JA, Mato AR, Wierda WG, Davids MS, Choi M, Cheson BD, Furman RR, Lamanna N, Barr PM, Zhou L, et al. 2018. Venetoclax for chronic lymphocytic leukaemia progressing after ibrutinib: An interim analysis of a multicentre, open-label, phase 2 trial. Lancet Oncol 19: 65-75. doi:10.1016/S1470-2045(17)30909-9

Kadri S, Lee J, Fitzpatrick C, Galanina N, Sukhanova M, Venkataraman G, Sharma S, Long B, Petras K, Theissen $\mathrm{M}$, et al. 2017. Clonal evolution underlying leukemia progression and Richter transformation in patients with ibrutinib-relapsed CLL. Blood Adv 1: 715-727. doi:10 .1182 /bloodadvances.2016003632

Kasar S, Kim J, Improgo R, Tiao G, Polak P, Haradhvala N, Lawrence MS, Kiezun A, Fernandes SM, Bahl S, et al. 2015. Whole-genome sequencing reveals activation-induced cytidine deaminase signatures during indolent chronic lymphocytic leukaemia evolution. Nat Commun 6: 8866 . doi:10.1038/ncomms 9866

Kasar S, Underbayev C, Hassan M, Ilev I, Degheidy H, Bauer S, Marti G, Lutz C, Raveche E, Batish M. 2016. Alterations in the mir-15a/16-1 loci impairs its processing and augments B-1 expansion in de novo mouse model of chronic lymphocytic leukemia (CLL). PLoS One 11: e0149331. doi:10.1371/journal.pone.0149331

Keating MJ, Kantarjian H, Talpaz M, Redman J, Koller C, Barlogie B, Velasquez W, Plunkett W, Freireich EJ, McCredie KB. 1989. Fludarabine: A new agent with major activity against chronic lymphocytic leukemia. Blood $\mathbf{7 4}$ 19-25. doi:10.1182/blood.V74.1.19.bloodjournal74119 
Keating MJ, Lerner S, Kantarjian H, Freireich EJ, O’Brien S 1995. The serum $\beta 2$-microglobulin level is more powerful than stage in predicting response and survival in chronic lymphocytic leukemia. Blood 86: 606A.

Keating MJ, O’Brien S, Albitar M, Lerner S, Plunkett W, Giles F, Andreeff M, Cortes J, Faderl S, Thomas D, et al. 2005. Early results of a chemoimmunotherapy regimen of fludarabine, cyclophosphamide, and rituximab as initial therapy for chronic lymphocytic leukemia. J Clin Oncol 23: 4079-4088. doi:10.1200/JCO.2005.12.051

Kesminiene A, Evrard A-S, Ivanov VK, Malakhova IV, Kurtinaitis J, Stengrevics A, Tekkel M, Anspaugh LR, Bouville A, Chekin S, et al. 2008. Risk of hematological malignancies among Chernobyl liquidators. Radiat Res 170: 721735. doi:10.1667/RR1231.1

Kikushige Y, Ishikawa F, Miyamoto T, Shima T, Urata S, Yoshimoto G, Mori Y, Iino T, Yamauchi T, Eto T, et al 2011. Self-renewing hematopoietic stem cell is the primary target in pathogenesis of human chronic lymphocytic leukemia. Cancer Cell 20: 246-259. doi:10.1016/j.ccr.2011 .06 .029

Kipps TJ, Tomhave E, Chen PP, Carson DA. 1988. Autoantibody-associated $\kappa$ light chain variable region gene expressed in chronic lymphocytic leukemia with little or no somatic mutation. Implications for etiology and immunotherapy. J Exp Med 167: 840-852. doi:10.1084/jem.167 .3 .840

Klein U, Tu Y, Stolovitzky GA, Mattioli M, Cattoretti G, Husson H, Freedman A, Inghirami G, Cro L, Baldini L, et al. 2001. Gene expression profiling of B cell chronic lymphocytic leukemia reveals a homogeneous phenotype related to memory B cells. J Exp Med 194: 1625-1638. doi:10.1084/jem.194.11.1625

Klein U, Lia M, Crespo M, Siegel R, Shen Q, Mo T, AmbesiImpiombato A, Califano A, Migliazza A, Bhagat G, et al. 2010. The DLEU2/miR-15a/16-1 cluster controls B cell proliferation and its deletion leads to chronic lymphocytic leukemia. Cancer Cell 17: 28-40. doi:10.1016/j.ccr.2009 .11 .019

Kochenderfer JN, Wilson WH, Janik JE, Dudley ME, StetlerStevenson M, Feldman SA, Maric I, Raffeld M, Nathan DA, Lanier BJ, et al. 2010. Eradication of B-lineage cells and regression of lymphoma in a patient treated with autologous $\mathrm{T}$ cells genetically engineered to recognize CD19. Blood 116: 4099-4102. doi:10.1182/blood-201004-281931

Kochenderfer JN, Dudley ME, Feldman SA, Wilson WH, Spaner DE, Maric I, Stetler-Stevenson M, Phan GQ, Hughes MS, Sherry RM, et al. 2012. B-cell depletion and remissions of malignancy along with cytokine-associated toxicity in a clinical trial of anti-CD19 chimericantigen-receptor-transduced T cells. Blood 119: 27092720. doi:10.1182/blood-2011-10-384388

Köhler F, Hug E, Eschbach C, Meixlsperger S, Hobeika E, Kofer J, Wardemann H, Jumaa H. 2008. Autoreactive B cell receptors mimic autonomous pre- $\mathrm{B}$ cell receptor signaling and induce proliferation of early B cells. Immunity 29: 912-921. doi:10.1016/j.immuni.2008.10.013

Komarova NL, Burger JA, Wodarz D. 2014. Evolution of ibrutinib resistance in chronic lymphocytic leukemia (CLL). Proc Natl Acad Sci 111: 13906-13911. doi:10 $.1073 /$ pnas. 1409362111
Kröber A, Seiler T, Benner A, Bullinger L, Bruckle E, Lichter P, Döhner H, Stilgenbauer S. 2002. $V_{H}$ mutation status, CD38 expression level, genomic aberrations, and survival in chronic lymphocytic leukemia. Blood 100: 1410-1416. doi:10.1182/blood.V100.4.1410.h81602001410_1410_ 1416

Kulis M, Heath S, Bibikova M, Queirós AC, Navarro A, Clot G, Martínez-Trillos A, Castellano G., Brun-Heath I, Pinyol M, et al. 2012. Epigenomic analysis detects widespread gene-body DNA hypomethylation in chronic lymphocytic leukemia. Nat Genet 44: 1236-1242. doi:10 .1038/ng.2443

Küppers R, Gause A, Rajewsky K. 1991. B cells of chronic lymphatic leukemia express $\mathrm{V}$ genes in unmutated form. Leuk Res 15: 487-496. doi:10.1016/0145-2126(91) 90060-7

Kwok M, Rawstron AC, Varghese A, Evans PAS, O'Connor SJM, Doughty C, Newton DJ, Moreton P, Hillmen P. 2016. Minimal residual disease is an independent predictor for 10-year survival in CLL. Blood 128: 2770-2773. doi:10.1182/blood-2016-05-714162

Lampson BL, Kasar SN, Matos TR, Morgan EA, Rassenti L, Davids MS, Fisher DC, Freedman AS, Jacobson CA, Armand P, et al. 2016. Idelalisib given front-line for treatment of chronic lymphocytic leukemia causes frequent immune-mediated hepatotoxicity. Blood 128: 195-203. doi:10.1182/blood-2016-03-707133

Landau DA, Carter Scott L, Stojanov P, McKenna A, Stevenson K, Lawrence Michael S, Sougnez C, Stewart C, Sivachenko A, Wang L, et al. 2013. Evolution and impact of subclonal mutations in chronic lymphocytic leukemia. Cell 152: 714-726. doi:10.1016/j.cell.2013.01.019

Landau DA, Carter SL, Getz G, Wu CJ. 2014a. Clonal evolution in hematological malignancies and therapeutic implications. Leukemia 28: 34-43. doi:10.1038/leu.2013.248

Landau DA, Clement K, Ziller Michael J, Boyle P, Fan J, Gu H, Stevenson K, Sougnez C, Wang L, Li S, et al. 2014b. Locally disordered methylation forms the basis of intratumor methylome variation in chronic lymphocytic leukemia. Cancer Cell 26: 813-825. doi:10.1016/j.ccell.2014 .10 .012

Landau DA, Tausch E, Taylor-Weiner AN, Stewart C, Reiter JG, Bahlo J, Kluth S, Bozic I, Lawrence M, Bottcher S, et al. 2015. Mutations driving CLL and their evolution in progression and relapse. Nature 526: 525-530. doi:10.1038/ nature15395

Landgren O, Gridley G, Check D, Caporaso NE, Morris Brown L. 2007a. Acquired immune-related and inflammatory conditions and subsequent chronic lymphocytic leukaemia. Br J Haematol 139: 791-798. doi:10.1111/j 1365-2141.2007.06859.x

Landgren O, Rapkin JS, Caporaso NE, Mellemkjaer L, Gridley G, Goldin LR, Engels EA. 2007b. Respiratory tract infections and subsequent risk of chronic lymphocytic leukemia. Blood 109: 2198-2201. doi:10.1182/blood2006-08-044008

Landgren O, Albitar M, Ma W, Abbasi F, Hayes RB, Ghia P, Marti GE, Caporaso N. 2009. B-cell clones as early markers for chronic lymphocytic leukemia. N Engl J Med 360: 659-667. doi:10.1056/NEJMoa0806122

Lanemo Myhrinder A, Hellqvist E, Sidorova E, Söderberg A, Baxendale H, Dahle C, Willander K, Tobin G, Bäckman E, 
N. Chiorazzi et al.

Söderberg O, et al. 2008. A new perspective: Molecular motifs on oxidized LDL, apoptotic cells, and bacteria are targets for chronic lymphocytic leukemia antibodies. Blood 111: 3838-3848. doi:10.1182/blood-2007-11125450

Law PJ, Berndt SI, Speedy HE, Camp NJ, Sava GP, Skibola CF, Holroyd A, Joseph V, Sunter NJ, Nieters A, et al. 2017. Genome-wide association analysis implicates dysregulation of immunity genes in chronic lymphocytic leukaemia. Nat Commun 8: 14175. doi:10.1038/ncomms14175

Lawrence MS, Stojanov P, Polak P, Kryukov GV, Cibulskis K, Sivachenko A, Carter SL, Stewart C, Mermel CH, Roberts SA, et al. 2013. Mutational heterogeneity in cancer and the search for new cancer-associated genes. Nature 499: 214-218. doi:10.1038/nature12213

Lee DW, Gardner R, Porter DL, Louis CU, Ahmed N, Jensen M, Grupp SA, Mackall CL. 2014. Current concepts in the diagnosis and management of cytokine release syndrome. Blood 124: 188-195.

Lenders JW, de Pauw BE, Bogman MJ, Haanen C. 1984. Combined immunodeficiency preceding chronic lymphocytic leukemia. Blut 48: 171-175. doi:10.1007/ BF00320340

Lentz R, Feinglass J, Ma S, Akhter N. 2019. Risk factors for the development of atrial fibrillation on ibrutinib treatment. Leuk Lymphoma 60: 1447-1453. doi:10.1080/ 10428194.2018.1533129

Lenz G, Nagel I, Siebert R, Roschke AV, Sanger W, Wright GW, Dave SS, Tan B, Zhao H, Rosenwald A, et al. 2007. Aberrant immunoglobulin class switch recombination and switch translocations in activated B cell-like diffuse large B cell lymphoma. J Exp Med 204: 633-643. doi:10 $.1084 /$ jem.20062041

Leon ME, Ferro G, Schüz J, Schinasi LH, Kjaerheim K, Straif K, Lebailly P, Tual S, Hofmann JN, Beane Freeman LE, et al. 2019. Pesticide use and risk of non-Hodgkin lymphoid malignancies in agricultural cohorts from France, Norway and the USA: A pooled analysis from the AGRICOH consortium. Int J Epidemiol 48: 1519-1535. doi:10.1093/ ije/dyz017

Lesley AA, Ola L, Eric AE. 2009. Common community acquired infections and subsequent risk of chronic lymphocytic leukaemia. Br J Haematol 147: 444-449. doi:10 $.1111 / \mathrm{j} .1365-2141.2009 .07849 . \mathrm{x}$

Leuenberger M, Frigerio S, Wild PJ, Noetzli F, Korol D, Zimmermann DR, Gengler C, Probst-Hensch NM, Moch H, Tinguely M. 2010. AID protein expression in chronic lymphocytic leukemia/small lymphocytic lymphoma is associated with poor prognosis and complex genetic alterations. Mod Pathol 23: 177-186. doi:10 .1038/modpathol.2009.156

Lipsky AH, Farooqui MZ, Tian X, Martyr S, Cullinane AM, Nghiem K, Sun C, Valdez J, Niemann CU, Herman SE, et al. 2015. Incidence and risk factors of bleeding-related adverse events in patients with chronic lymphocytic leukemia treated with ibrutinib. Haematologica 100: 15711578. doi:10.3324/haematol.2015.126672

Liu Y, Higgins CD, Overstreet CM, Rai KR, Chiorazzi N, Lai JR. 2013. Peptides that bind specifically to an antibody from a chronic lymphocytic leukemia clone expressing unmutated immunoglobulin variable region genes. $\mathrm{Mol}$ Med 19: 245-252. doi:10.2119/molmed.2013.00082
Ljungström V, Cortese D, Young E, Pandzic T, Mansouri L, Plevova K, Ntoufa S, Baliakas P, Clifford R, Sutton LA, et al. 2016. Whole-exome sequencing in relapsing chronic lymphocytic leukemia: Clinical impact of recurrent RPS15 mutations. Blood 127: 1007-1016. doi:10.1182/ blood-2015-10-674572

Logan AC, Gao H, Wang C, Sahaf B, Jones CD, Marshall EL, Buño I, Armstrong R, Fire AZ, Weinberg KI, et al. 2011. High-throughput VDJ sequencing for quantification of minimal residual disease in chronic lymphocytic leukemia and immune reconstitution assessment. Proc Natl Acad Sci 108: 21194-21199. doi:10.1073/pnas .1118357109

Logan AC, Zhang B, Narasimhan B, Carlton V, Zheng J, Moorhead M, Krampf MR, Jones CD, Waqar AN, Faham $\mathrm{M}$, et al. 2013. Minimal residual disease quantification using consensus primers and high-throughput IGH sequencing predicts post-transplant relapse in chronic lymphocytic leukemia. Leukemia 27: 1659-1665. doi:10 $.1038 /$ leu.2013.52

Maddocks KJ, Ruppert AS, Lozanski G, Heerema NA, Zhao W, Abruzzo L, Lozanski A, Davis M, Gordon A, Smith LL, et al. 2015. Etiology of ibrutinib therapy discontinuation and outcomes in patients with chronic lymphocytic leukemia. JAMA Oncol 1: 80-87. doi:10.1001/jamaoncol .2014 .218

Maffei R, Fiorcari S, Martinelli S, Potenza L, Luppi M, Marasca R. 2015. Targeting neoplastic B cells and harnessing microenvironment: The "double face" of ibrutinib and idelalisib. J Hematol Oncol 8: 60. doi:10.1186/s13045015-0157-x

Mandrekar SJ, Sargent DJ. 2010. Predictive biomarker validation in practice: Lessons from real trials. Clin Trials 7: 567-573. doi:10.1177/1740774510368574

Mansouri L, Wierzbinska JA, Plass C, Rosenquist R. 2018. Epigenetic deregulation in chronic lymphocytic leukemia: Clinical and biological impact. Semin Cancer Biol 51: 1-11. doi:10.1016/j.semcancer.2018.02.001

Mao Z, Quintanilla-Martinez L, Raffeld M, Richter M, Krugmann J, Burek C, Hartmann E, Rudiger T, Jaffe ES, Müller-Hermelink HK, et al. 2007. IgVH mutational status and clonality analysis of Richter's transformation: Diffuse large B-cell lymphoma and Hodgkin lymphoma in association with B-cell chronic lymphocytic leukemia (BCLL) represent 2 different pathways of disease evolution. Am J Surg Pathol 31: 1605-1614. doi:10.1097/PAS .0b013e31804bdaf8

Marsilio S, Khiabanian H, Fabbri G, Vergani S, Scuoppo C, Montserrat E, Shpall EJ, Hadigol M, Marin P, Rai KR, et al. 2018. Somatic CLL mutations occur at multiple distinct hematopoietic maturation stages: Documentation and cautionary note regarding cell fraction purity. Leukemia 32: 1041-1044. doi:10.1038/leu.2017.343

Marti GE, Carter P, Abbasi F, Washington GC, Jain N, Zenger VE, Ishibe N, Goldin L, Fontaine L, Weissman N, et al. 2003. B-cell monoclonal lymphocytosis and B-cell abnormalities in the setting of familial B-cell chronic lymphocytic leukemia. Cytometry B Clin Cytom 52B: 1-12. doi:10 $.1002 /$ cyto.b. 10013

Marti GE, Rawstron AC, Ghia P, Hillmen P, Houlston RS, Kay N, Schleinitz TA, Caporaso N. 2005. Diagnostic cri- 
teria for monoclonal B-cell lymphocytosis. Br J Haematol 130: 325-332. doi:10.1111/j.1365-2141.2005.05550.x

Matos DM, Ismael SJ, Scrideli CA, de Oliveira FM, Rego EM, Falcão RP. 2009. Monoclonal B-cell lymphocytosis in first-degree relatives of patients with sporadic (non-familial) chronic lymphocytic leukaemia. $\mathrm{Br} J$ Haematol 147: 339-346. doi:10.1111/j.1365-2141.2009.07861.x

McCarthy H, Wierda WG, Barron LL, Cromwell CC, Wang J, Coombes KR, Rangel R, Elenitoba-Johnson KS, Keating MJ, Abruzzo LV. 2003. High expression of activation-induced cytidine deaminase (AID) and splice variants is a distinctive feature of poor-prognosis chronic lymphocytic leukemia. Blood 101: 4903-4908. doi:10.1182/blood2002-09-2906

McClanahan F, Hanna B, Miller S, Clear AJ, Lichter P, Gribben JG, Seiffert M. 2015. PD-L1 checkpoint blockade prevents immune dysfunction and leukemia development in a mouse model of chronic lymphocytic leukemia. Blood 126: 203-211. doi:10.1182/blood-2015-01-622936

McMullen JR, Boey EJ, Ooi JY, Seymour JF, Keating MJ, Tam CS. 2014. Ibrutinib increases the risk of atrial fibrillation, potentially through inhibition of cardiac PI3K-Akt signaling. Blood 124: 3829-3830. doi:10.1182/blood-201410-604272

Meeker TC, Grimaldi JC, O’Rourke R, Loeb J, Juliusson G, Einhorn S. 1988. Lack of detectable somatic hypermutation in the $\mathrm{V}$ region of the Ig $\mathrm{H}$ chain gene of a human chronic B lymphocytic leukemia. J Immunol 141: 39943998.

Mescher C, Gilbertson D, Randall NM, Tarchand G Tomaska J, Baumann Kreuziger L, Morrison VA. 2018. The impact of Agent Orange exposure on prognosis and management in patients with chronic lymphocytic leukemia: A National Veteran Affairs Tumor Registry study. Leuk Lymphoma 59: 1348-1355. doi:10.1080/10428194 .2017

Messina M, Del Giudice I, Khiabanian H, Rossi D, Chiaretti S, Rasi S, Spina V, Holmes AB, Marinelli M, Fabbri G, et al. 2014. Genetic lesions associated with chronic lymphocytic leukemia chemo-refractoriness. Blood 123: 23782388. doi:10.1182/blood-2013-10-534271

Messmer BT, Albesiano E, Efremov DG, Ghiotto F, Allen SL, Kolitz J, Foa R, Damle RN, Fais F, Messmer D, et al. 2004. Multiple distinct sets of stereotyped antigen receptors indicate a role for antigen in promoting chronic lymphocytic leukemia. J Exp Med 200: 519-525. doi:10.1084/jem .20040544

Messmer BT, Messmer D, Allen SL, Kolitz JE, Kudalkar P, Cesar D, Murphy EJ, Koduru P, Ferrarini M, Zupo S, et al. 2005. In vivo measurements document the dynamic cellular kinetics of chronic lymphocytic leukemia B cells. J Clin Invest 115: 755-764. doi:10.1172/JCI23409

Minici C, Gounari M, Übelhart R, Scarfò L, Dühren-von Minden M, Schneider D, Tasdogan A, Alkhatib A, Agathangelidis A, Ntoufa S, et al. 2017. Distinct homotypic Bcell receptor interactions shape the outcome of chronic lymphocytic leukaemia. Nat Commun 8: 15746. doi:10 .1038/ncomms 15746

Molica S, Alberti A. 1987. Prognostic value of the lymphocyte doubling time in chronic lymphocytic leukemia. Cancer 60: 2712-2716. doi:10.1002/1097-0142(19871201)60 :11<2712::AID-CNCR2820601122>3.0.CO;2-1
Molica S, Mauro FR, Callea V, Giannarelli D, Lauria F, Rotoli B, Cortelezzi A, Liso V, Foa R. 2010. The utility of a prognostic index for predicting time to first treatment in early chronic lymphocytic leukemia: The GIMEMA experience. Haematologica 95: 464-469. doi:10.3324/hae matol.2009.011767

Molica S, Mauro FR, Giannarelli D, Lauria F, Cortelezzi A, Brugiatelli M, Liso V, Cuneo A, Foà R. 2011. Differentiating chronic lymphocytic leukemia from monoclonal Blymphocytosis according to clinical outcome: On behalf of the GIMEMA chronic lymphoproliferative diseases working group. Haematologica 96: 277-283. doi:10 .3324/haematol.2010.030189

Molica S, Giannarelli D, Mirabelli R, Levato L, Kay NE, Shanafelt TD. 2018. Chronic lymphocytic leukemia international prognostic index: A systematic review and meta-analysis. Blood 131: 365-368. doi:10.1182/blood2017-09-806034

Montecino-Rodriguez E, Leathers H, Dorshkind K. 2006. Identification of a B-1 B cell-specified progenitor. Nat Immunol 7: 293-301. doi:10.1038/ni1301

Montserrat E. 2012. CLL therapy: The increasing importance of predictive markers. Oncology (Williston Park) 26: 1064-1066.

Montserrat E, Sanchez-Bisono J, Viñolas N, Rozman C. 1986. Lymphocyte doubling time in chronic lymphocytic leukaemia: Analysis of its prognostic significance. $\mathrm{Br} \mathrm{J}$ Haematol 62: 567-575. doi:10.1111/j.1365-2141.1986 .tb02969.x

Moreira J, Rabe KG, Cerhan JR, Kay NE, Wilson JW, Call TG, Leis JF, Jelinek DF, Schwager SM, Bowen DA, et al. 2013. Infectious complications among individuals with clinical monoclonal B-cell lymphocytosis (MBL): A cohort study of newly diagnosed cases compared to controls. Leukemia 27: 136-141. doi:10.1038/leu.2012.187

Muramatsu M, Sankaranand VS, Anant S, Sugai M, Kinoshita K, Davidson NO, Honjo T. 1999. Specific expression of activation-induced cytidine deaminase (AID), a novel member of the RNA-editing deaminase family in germinal center B cells. J Biol Chem 274: 18470-18476. doi:10 $.1074 /$ jbc. 274.26 .18470

Muramatsu M, Kinoshita K, Fagarasan S, Yamada S, Shinkai Y, Honjo T. 2000. Class switch recombination and hypermutation require activation-induced cytidine deaminase (AID), a potential RNA editing enzyme. Cell 102: 553563. doi:10.1016/S0092-8674(00)00078-7

Murphy EJ, Neuberg DS, Rassenti LZ, Hayes G, Redd R, Emson C, Li K, Brown JR, Wierda WG, Turner S, et al. 2017. Leukemia-cell proliferation and disease progression in patients with early stage chronic lymphocytic leukemia. Leukemia 31: 1348-1354. doi:10.1038/leu.2017.34

Murray F, Darzentas N, Hadzidimitriou A, Tobin G, Boudjogra M, Scielzo C, Laoutaris N, Karlsson K, Baran-Marzsak F, Tsaftaris A, et al. 2008. Stereotyped patterns of somatic hypermutation in subsets of patients with chronic lymphocytic leukemia: Implications for the role of antigen selection in leukemogenesis. Blood 111: 1524-1533. doi:10.1182/blood-2007-07-099564

Nadeu F, Clot G, Delgado J, Martín-García D, Baumann T, Salaverria I, Beà $S$, Pinyol $M$, Jares $P$, Navarro $A$, et al. 2018. Clinical impact of the subclonal architecture and 
N. Chiorazzi et al.

mutational complexity in chronic lymphocytic leukemia. Leukemia 32: 645-653. doi:10.1038/leu.2017.291

Niedermeier M, Hennessy BT, Knight ZA, Henneberg M, $\mathrm{Hu}$ J, Kurtova AV, Wierda WG, Keating MJ, Shokat KM Burger JA. 2009. Isoform-selective phosphoinositide $3^{\prime}$ kinase inhibitors inhibit CXCR4 signaling and overcome stromal cell-mediated drug resistance in chronic lymphocytic leukemia: A novel therapeutic approach. Blood 113: 5549-5557. doi:10.1182/blood-2008-06-165068

Niemann CU, Herman SE, Maric I, Gomez-Rodriguez J, Biancotto A, Chang BY, Martyr S, Stetler-Stevenson M, Yuan CM, Calvo KR, et al. 2016. Disruption of in vivo chronic lymphocytic leukemia tumor-microenvironment interactions by ibrutinib-Findings from an investigator-initiated phase II study. Clin Cancer Res 22: 15721582. doi:10.1158/1078-0432.CCR-15-1965

Nishio M, Endo T, Tsukada N, Ohata J, Kitada S, Reed JC, Zvaifler NJ, Kipps TJ. 2005. Nurselike cells express BAFF and APRIL, which can promote survival of chronic lymphocytic leukemia cells via a paracrine pathway distinct from that of SDF-1 $\alpha$. Blood 106: 1012-1020. doi:10.1182/ blood-2004-03-0889

Nogueira V, Hay N. 2013. Molecular pathways: Reactive oxygen species homeostasis in cancer cells and implications for cancer therapy. Clin Cancer Res 19: 4309-4314. doi:10.1158/1078-0432.CCR-12-1424

Oakes CC, Claus R, Gu L, Assenov Y, Hüllein J, Zucknick M, Bieg M, Brocks D, Bogatyrova O, Schmidt CR, et al. 2014 Evolution of DNA methylation is linked to genetic aberrations in chronic lymphocytic leukemia. Cancer Discov 4: 348-361. doi:10.1158/2159-8290.CD-13-0349

Oakes CC, Seifert M, Assenov Y, Gu L, Przekopowitz M, Ruppert AS, Wang Q, Imbusch CD, Serva A, Koser SD, et al. 2016. DNA methylation dynamics during B cell maturation underlie a continuum of disease phenotypes in chronic lymphocytic leukemia. Nat Genet 48: 253-264. doi:10.1038/ng.3488

Ojha J, Secreto C, Rabe K, Ayres-Silva J, Tschumper R, Dyke DV, Slager S, Fonseca R, Shanafelt T, Kay N, et al. 2014 Monoclonal B-cell lymphocytosis is characterized by mutations in CLL putative driver genes and clonal heterogeneity many years before disease progression. Leukemia 28: 2395-2398. doi:10.1038/leu.2014.226

Ojha J, Ayres J, Secreto C, Tschumper R, Rabe K, Van Dyke D, Slager S, Shanafelt T, Fonseca R, Kay NE, et al. 2015. Deep sequencing identifies genetic heterogeneity and recurrent convergent evolution in chronic lymphocytic leukemia. Blood 125: 492-498. doi:10.1182/blood-2014-06580563

Oldenhuis CNAM, Oosting SF, Gietema JA, de Vries EGE. 2008. Prognostic versus predictive value of biomarkers in oncology. Eur J Cancer 44: 946-953. doi:10.1016/j.ejca .2008 .03 .006

Oltra AM, Carbonell F, Tormos C, Iradi A, Sáez GT. 2001. Antioxidant enzyme activities and the production of MDA and 8-oxo-dG in chronic lymphocytic leukemia. Free Radic Biol Med 30: 1286-1292. doi:10.1016/S08915849(01)00521-4

Oppezzo P, Vuillier F, Vasconcelos Y, Dumas G, Magnac C, Payelle-Brogard B, Pritsch O, Dighiero G. 2003. Chronic lymphocytic leukemia B cells expressing AID display dissociation between class switch recombination and so- matic hypermutation. Blood 101: 4029-4032. doi:10 .1182/blood-2002-10-3175

Ortolano S, Hwang IY, Han SB, Kehrl JH. 2006. Roles for phosphoinositide 3-kinases, Bruton's tyrosine kinase, and Jun kinases in B lymphocyte chemotaxis and homing. Eur JImmunol 36: 1285-1295. doi:10.1002/eji.200535799

Os A, Bürgler S, Ribes Anna P, Funderud A, Wang D, Thompson Keith M, Tjønnfjord Geir E, Bogen B, Munthe Ludvig A. 2013. Chronic lymphocytic leukemia cells are activated and proliferate in response to specific $\mathrm{T}$ helper cells. Cell Rep 4: 566-577. doi:10.1016/j.celrep .2013.07.011

Pan LX, Diss TC, Peng HZ, Norton AJ, Isaacson PG. 1996. Nodular lymphocyte predominance Hodgkin's disease: A monoclonal or polyclonal B-cell disorder? Blood 87: 2428-2434. doi:10.1182/blood.V87.6.2428.bloodjournal 8762428

Parikh SA, Chaffee KG, Larson MC, Hampel PJ, Call TG, Ding W, Kenderian SS, Leis JF, Chanan-Khan AA, Conte MJ, et al. 2018. Outcomes of a large cohort of individuals with clinically ascertained high-count monoclonal B-cell lymphocytosis. Haematologica 103: e237-e240. doi:10 .3324/haematol.2017.183194

Pasqualucci L, Migliazza A, Fracchiolla N, William C, Neri A, Baldini L, Chaganti RSK, Klein U, Kuppers R, Rajewsky K, et al. 1998. BCL-6 mutations in normal germinal center B cells: Evidence of somatic hypermutation acting outside Ig loci. Proc Natl Acad Sci 95: 11816-11821. doi:10.1073/pnas.95.20.11816

Pasqualucci L, Neumeister P, Goossens T, Nanjangud G, Chaganti RS, Küppers R, Dalla-Favera R. 2001. Hypermutation of multiple proto-oncogenes in B-cell diffuse large-cell lymphomas. Nature 412: 341-346. doi:10 $.1038 / 35085588$

Pasqualucci L, Guglielmino R, Houldsworth J, Mohr J, Aoufouchi S, Polakiewicz R, Chaganti RSK, Dalla-Favera R. 2004. Expression of the AID protein in normal and neoplastic B cells. Blood 104: 3318-3325. doi:10.1182/blood2004-04-1558

Patten PE, Chu CC, Albesiano E, Damle RN, Yan XJ, Kim D, Zhang L, Magli AR, Barrientos J, Kolitz JE, et al. 2012 IGHV-unmutated and IGHV-mutated chronic lymphocytic leukemia cells produce activation-induced deaminase protein with a full range of biologic functions. Blood 120: 4802-4811. doi:10.1182/blood-2012-08-449744

Patten PE, Ferrer G, Chen SS, Simone R, Marsilio S, Yan XJ, Gitto Z, Yuan C, Kolitz JE, Barrientos J, et al. 2016. Chronic lymphocytic leukemia cells diversify and differentiate in vivo via a nonclassical Th1-dependent, Bcl-6deficient process. JCI Insight 1: e86288. doi:10.1172/jci .insight. 86288

Petersen CT, Hassan M, Morris AB, Jeffery J, Lee K, Jagirdar N, Staton AD, Raikar SS, Spencer HT, Sulchek T, et al 2018. Improving T-cell expansion and function for adoptive T-cell therapy using ex vivo treatment with PI3K $\delta$ inhibitors and VIP antagonists. Blood Adv 2: 210-223. doi:10.1182/bloodadvances.2017011254

Pleasance ED, Stephens PJ, O’Meara S, McBride DJ, Meynert A, Jones D, Lin ML, Beare D, Lau KW, Greenman C, et al. 2010. A small-cell lung cancer genome with complex signatures of tobacco exposure. Nature 463: 184-190. doi:10 $.1038 /$ nature 08629 
Ponader S, Chen S-S, Buggy JJ, Balakrishnan K, Gandhi V, Wierda WG, Keating MJ, O’Brien S, Chiorazzi N, Burger JA. 2012. The Bruton tyrosine kinase inhibitor PCI-32765 thwarts chronic lymphocytic leukemia cell survival and tissue homing in vitro and in vivo. Blood 119: 1182-1189. doi:10.1182/blood-2011-10-386417

Popp HD, Flach J, Brendel S, Ruppenthal S, Kleiner H, Seifarth W, Schneider S, Schulze TJ, Weiss C, Wenz F, et al. 2019. Accumulation of DNA damage and alteration of the DNA damage response in monoclonal B-cell lymphocytosis and chronic lymphocytic leukemia. Leuk Lymphoma 60: 795-804. doi:10.1080/10428194.2018.1498494

Porter DL, Levine BL, Kalos M, Bagg A, June CH. 2011 Chimeric antigen receptor-modified $\mathrm{T}$ cells in chronic lymphoid leukemia. $N$ Engl J Med 365: 725-733. doi:10 .1056/NEJMoa1103849

Pozzo F, Bittolo T, Arruga F, Bulian P, Macor P, Tissino E, Gizdic B, Rossi FM, Bomben R, Zucchetto A, et al. 2016. NOTCH1 mutations associate with low CD20 level in chronic lymphocytic leukemia: Evidence for a NOTCH1 mutation-driven epigenetic dysregulation. Leukemia 30: 182-189. doi:10.1038/leu.2015.182

Pratt LF, Rassenti L, Larrick J, Robbins B, Banks PM, Kipps TJ. 1989. Ig V region gene expression in small lymphocytic lymphoma with little or no somatic hypermutation. J Immunol 143: 699-705.

Preston DL, Kusumi S, Tomonaga M, Izumi S, Ron E, Kuramoto A, Kamada N, Dohy H, Matsuo T, Matsui T, et al. 1994. Cancer incidence in atomic bomb survivors. Part III: Leukemia, lymphoma and multiple myeloma, 19501987. Radiat Res 137: S68-S97. doi:10.2307/3578893

Puente XS, Pinyol M, Quesada V, Conde L, Ordóñez GR, Villamor N, Escaramis G, Jares P, Beà S, González-Díaz $\mathrm{M}$, et al. 2011. Whole-genome sequencing identifies recurrent mutations in chronic lymphocytic leukaemia. $\mathrm{Na}$ ture 475: 101-105. doi:10.1038/nature10113

Puente XS, Beà S, Valdés-Mas R, Villamor N, GutiérrezAbril J, Martín-Subero JI, Munar M, Rubio-Pérez C, Jares $\mathrm{P}$, Aymerich M, et al. 2015. Non-coding recurrent mutations in chronic lymphocytic leukaemia. Nature 526: 519-524. doi:10.1038/nature14666

Queirós AC, Villamor N, Clot G, Martinez-Trillos A, Kulis M, Navarro A, Penas EMM, Jayne S, Majid A, Richter J, et al. 2015. A B-cell epigenetic signature defines three biological subgroups of chronic lymphocytic leukemia with clinical impact. Leukemia 29: 598-605. doi:10.1038/leu .2014 .252

Quesada V, Conde L, Villamor N, Ordóñez GR, Jares P, Bassaganyas L, Ramsay AJ, Beà S, Pinyol M, MartínezTrillos A, et al. 2011. Exome sequencing identifies recurrent mutations of the splicing factor SF3B1 gene in chronic lymphocytic leukemia. Nat Genet 44: 47-52. doi:10.1038/ng.1032

Quesada V, Ramsay AJ, Lopez-Otin C. 2012. Chronic lymphocytic leukemia with SF3B1 mutation. $N$ Engl J Med 366: 2530. doi:10.1056/NEJMc1204033

Quesada V, Ramsay AJ, Rodriguez D, Puente XS, Campo E, Lopez-Otin C. 2013. The genomic landscape of chronic lymphocytic leukemia: clinical implications. BMC Med 11: 124. doi:10.1186/1741-7015-11-124

Rai KR, Sawitsky A, Cronkite EP, Chanana AD, Levy RN, Pasternack BS. 1975. Clinical staging of chronic lympho- cytic leukemia. Blood 46: 219-234. doi:10.1182/blood .V46.2.219.219

Ramsay AG, Johnson AJ, Lee AM, Gorgun G, Le Dieu R, Blum W, Byrd JC, Gribben JG. 2008. Chronic lymphocytic leukemia $\mathrm{T}$ cells show impaired immunological synapse formation that can be reversed with an immunomodulating drug. J Clin Invest 118: 2427-2437.

Rasi S, Monti S, Spina V, Foà R, Gaidano G, Rossi D. 2012. Analysis of NOTCH1 mutations in monoclonal B-cell lymphocytosis. Haematologica 97: 153-154. doi:10 .3324/haematol.2011.053090

Rassenti LZ, Jain S, Keating MJ, Wierda WG, Grever MR, Byrd JC, Kay NE, Brown JR, Gribben JG, Neuberg DS, et al. 2008. Relative value of ZAP-70, CD38, and immunoglobulin mutation status in predicting aggressive disease in chronic lymphocytic leukemia. Blood 112: 1923-1930. doi:10.1182/blood-2007-05-092882

Raveche ES, Salerno E, Scaglione BJ, Manohar V, Abbasi F, Lin Y-C, Fredrickson T, Landgraf P, Ramachandra S, Huppi K, et al. 2007. Abnormal microRNA-16 locus with synteny to human 13q14 linked to CLL in NZB mice. Blood 109: 5079-5086. doi:10.1182/blood-200702-071225

Rawstron AC, Green MJ, Kuzmicki A, Kennedy B, Fenton JA, Evans PA, O'Connor SJ, Richards SJ, Morgan GJ, Jack AS, et al. 2002a. Monoclonal B lymphocytes with the characteristics of "indolent" chronic lymphocytic leukemia are present in $3.5 \%$ of adults with normal blood counts. Blood 100: 635-639. doi:10.1182/blood.V100.2 .635

Rawstron AC, Yuille MR, Fuller J, Cullen M, Kennedy B, Richards SJ, Jack AS, Matutes E, Catovsky D, Hillmen $\mathrm{P}$, et al. 2002b. Inherited predisposition to CLL is detectable as subclinical monoclonal B-lymphocyte expansion Blood 100: 2289-2290. doi:10.1182/blood-2002-03-0892

Rawstron AC, Bennett FL, O'Connor SJM, Kwok M, Fenton JAL, Plummer M, de Tute R, Owen RG, Richards SJ, Jack AS, et al. 2008. Monoclonal B-cell lymphocytosis and chronic lymphocytic leukemia. N Engl J Med 359: 575583. doi:10.1056/NEJMoa075290

Rawstron AC, Böttcher S, Letestu R, Villamor N, Fazi C, Kartsios H, de Tute RM, Shingles J, Ritgen M, Moreno C, et al. 2013. Improving efficiency and sensitivity: European Research Initiative in CLL (ERIC) update on the international harmonised approach for flow cytometric residual disease monitoring in CLL. Leukemia 27: 142149. doi:10.1038/leu.2012.216

Rawstron AC, Fazi C, Agathangelidis A, Villamor N, Letestu R, Nomdedeu J, Palacio C, Stehlikova O, Kreuzer KA, Liptrot S, et al. 2015. A complementary role of multiparameter flow cytometry and high-throughput sequencing for minimal residual disease detection in chronic lymphocytic leukemia: An European research initiative on CLL study. Leukemia 30: 929-936. doi:10.1038/leu.2015 .313

Reiniger L, Bödör C, Bognár A, Balogh Z, Csomor J, Szepesi A, Kopper L, Matolcsy A. 2006. Richter's and prolymphocytic transformation of chronic lymphocytic leukemia are associated with high mRNA expression of activation-induced cytidine deaminase and aberrant somatic hypermutation. Leukemia 20: 1089-1095. doi:10.1038/sj.leu .2404183 
N. Chiorazzi et al.

Richter MN. 1928. Generalized reticular cell sarcoma of lymph nodes associated with lymphatic leukemia. Am J Pathol 4: 285-292 287.

Robbiani DF, Bunting S, Feldhahn N, Bothmer A, Camps J, Deroubaix S, McBride KM, Klein IA, Stone G, Eisenreich TR, et al. 2009. AID produces DNA double-strand breaks in non-Ig genes and mature B cell lymphomas with reciprocal chromosome translocations. Mol Cell 36: 631641. doi:10.1016/j.molcel.2009.11.007

Roberts AW, Davids MS, Pagel JM, Kahl BS, Puvvada SD, Gerecitano JF, Kipps TJ, Anderson MA, Brown JR, Gressick L, et al. 2016. Targeting BCL2 with venetoclax in relapsed chronic lymphocytic leukemia. $N$ Engl J Med 374: 311-322. doi:10.1056/NEJMoa1513257

Rodríguez-Vicente AE, Bikos V, Hernández-Sánchez M, Malcikova J, Hernández-Rivas JM, Pospisilova S. 2017. Next-generation sequencing in chronic lymphocytic leukemia: Recent findings and new horizons. Oncotarget 8: 71234-71248. doi:10.18632/oncotarget.19525

Rogers KA, Huang Y, Dotson E, Lundberg J, Andritsos LA Awan FT, Woyach JA, Byrd JC. 2019. Use of PD-1 (PDCD1) inhibitors for the treatment of Richter syndrome: Experience at a single academic centre. $B J$ Haematol 185: 363-366. doi:10.1111/bjh.15508

Romanenko A, Bebeshko V, Hatch M, Bazyka D, Finch S, Dyagil I, Reiss R, Chumak V, Bouville A, Gudzenko N, et al. 2008. The Ukrainian-American study of leukemia and related disorders among Chernobyl cleanup workers from Ukraine: I. Study methods. Radiat Res 170: 691697. doi:10.1667/RR1402.1

Romero D. 2017. After ibrutinib, CAR T cells induce responses. Nat Rev Clin Oncol 14: 588. doi:10.1038/nrcli nonc.2017.124

Rosenwald A, Alizadeh AA, Widhopf G, Simon R, Davis RE, Yu X, Yang L, Pickeral OK, Rassenti LZ, Powell J, et al. 2001. Relation of gene expression phenotype to immunoglobulin mutation genotype in $\mathrm{B}$ cell chronic lymphocytic leukemia. J Exp Med 194: 1639-1648. doi:10.1084/jem .194 .11 .1639

Rose-Zerilli MJ, Gibson J, Wang J, Tapper W, Davis Z, Parker H, Larrayoz M, McCarthy H, Walewska R, Forster J, et al. 2016. Longitudinal copy number, whole exome and targeted deep sequencing of 'good risk' IGHV-mutated CLL patients with progressive disease. Leukemia 30: 1301-1310. doi:10.1038/leu.2016.10

Rossi D, Zucchetto A, Rossi FM, Capello D, Cerri M, Deambrogi C, Cresta S, Rasi S, De Paoli L, Bodoni CL, et al. 2008. CD49d expression is an independent risk factor of progressive disease in early stage chronic lymphocytic leukemia. Haematologica 93: 1575-1579. doi:10.3324/ haematol.13103

Rossi D, Sozzi E, Puma A, De Paoli L, Rasi S, Spina V, Gozzetti A, Tassi M, Cencini E, Raspadori D, et al. 2009a. The prognosis of clinical monoclonal B cell lymphocytosis differs from prognosis of Rai 0 chronic lymphocytic leukaemia and is recapitulated by biological risk factors. Br J Haematol 146: 64-75. doi:10.1111/j.13652141.2009.07711.x

Rossi D, Spina V, Cerri M, Rasi S, Deambrogi C, De Paoli L, Laurenti L, Maffei R, Forconi F, Bertoni F, et al. 2009b. Stereotyped B-cell receptor is an independent risk factor of chronic lymphocytic leukemia transformation to Rich- ter syndrome. Clin Cancer Res 15: 4415-4422. doi:10 .1158/1078-0432.CCR-08-3266

Rossi D, Rasi S, Fabbri G, Spina V, Fangazio M, Forconi F, Marasca R, Laurenti L, Bruscaggin A, Cerri M, et al. 2012a. Mutations of NOTCH1 are an independent predictor of survival in chronic lymphocytic leukemia. Blood 119: 521-529. doi:10.1182/blood-2011-09-379966

Rossi D, Rasi S, Spina V, Fangazio M, Monti S, Greco M, Ciardullo C, Famà R, Cresta S, Bruscaggin A, et al. 2012b. Different impact of NOTCH1 and SF3B1 mutations on the risk of chronic lymphocytic leukemia transformation to Richter syndrome. Br J Haematol 158: 426-429. doi:10 $.1111 / \mathrm{j} .1365-2141.2012 .09155 . x$

Rossi D, Rasi S, Spina V, Bruscaggin A, Monti S, Ciardullo C, Deambrogi C, Khiabanian H, Serra R, Bertoni F, et al. 2013. Integrated mutational and cytogenetic analysis identifies new prognostic subgroups in chronic lymphocytic leukemia. Blood 121: 1403-1412. doi:10.1182/ blood-2012-09-458265

Rossi D, Terzi-di-Bergamo L, De Paoli L, Cerri M, Ghilardi G, Chiarenza A, Bulian P, Visco C, Mauro FR, Morabito F, et al. 2015. Molecular prediction of durable remission after first-line fludarabine-cyclophosphamide-rituximab in chronic lymphocytic leukemia. Blood 126: 1921-1924. doi:10.1182/blood-2015-05-647925

Ruefli-Brasse A, Reed JC. 2017. Therapeutics targeting Bcl-2 in hematological malignancies. Biochem J 474: 3643 3657. doi:10.1042/BCJ20170080

Rush JS, Liu M, Odegard VH, Unniraman S, Schatz DG. 2005. Expression of activation-induced cytidine deaminase is regulated by cell division, providing a mechanistic basis for division-linked class switch recombination. Proc Natl Acad Sci 102: 13242-13247. doi:10.1073/pnas .0502779102

Sarkar M, Liu Y, Morimoto J, Peng H, Aquino C, Rader C, Chiorazzi N, Kodadek T. 2014. Recognition of antigenspecific B-cell receptors from chronic lymphocytic leukemia patients by synthetic antigen surrogates. Chem Biol 21: 1670-1679. doi:10.1016/j.chembiol.2014.10.010

Sarkar M, Liu Y, Qi J, Peng H, Morimoto J, Rader C, Chiorazzi N, Kodadek T. 2016. Targeting stereotyped B cell receptors from chronic lymphocytic leukemia patients with synthetic antigen surrogates. J Biol Chem 291: 7558-7570. doi:10.1074/jbc.M115.701656

Schena M, Larsson LG, Gottardi D, Gaidano G, Carlsson M, Nilsson K, Caligaris-Cappio F. 1992. Growth- and differentiation-associated expression of bcl-2 in B-chronic lymphocytic leukemia cells. Blood 79: 2981-2989. doi:10.1182/blood.V79.11.2981.2981

Schmid C, Isaacson PG. 1994. Proliferation centres in B-cell malignant lymphoma, lymphocytic (B-CLL): An immunophenotypic study. Histopathology 24: 445-451. doi:10 $.1111 /$ j.1365-2559.1994.tb00553.x

Schroeder HW Jr, Dighiero G. 1994. The pathogenesis of chronic lymphocytic leukemia: Analysis of the antibody repertoire. Immunol Today 15: 288-294. doi:10.1016/ 0167-5699(94)90009-4

Schwartz GG, Klug MG. 2016. Incidence rates of chronic lymphocytic leukemia in US states are associated with residential radon levels. Future Oncol 12: 165-174. doi:10.2217/fon.15.275 
Seifert M, Sellmann L, Bloehdorn J, Wein F, Stilgenbauer S, Durig J, Küppers R. 2012. Cellular origin and pathophysiology of chronic lymphocytic leukemia. J Exp Med 209: 2183-2198. doi:10.1084/jem.20120833

Shanafelt TD, Geyer SM, Bone ND, Tschumper RC, Witzig TE, Nowakowski GS, Zent CS, Call TG, Laplant B, Dewald $\mathrm{GW}$, et al. 2008a. CD49d expression is an independent predictor of overall survival in patients with chronic lymphocytic leukaemia: A prognostic parameter with therapeutic potential. Br J Haematol 140: 537-546. doi:10 $.1111 / \mathrm{j} .1365-2141.2007 .06965 . \mathrm{x}$

Shanafelt TD, Hanson C, Dewald GW, Witzig TE, LaPlant B, Abrahamzon J, Jelinek DF, Kay NE. 2008b. Karyotype evolution on fluorescent in situ hybridization analysis is associated with short survival in patients with chronic lymphocytic leukemia and is related to CD49d expression. J Clin Oncol 26: e5-e6. doi:10.1200/JCO.2008.16 .7874

Shanafelt TD, Kay NE, Jenkins G, Call TG, Zent CS, Jelinek DF, Morice WG, Boysen J, Zakko L, Schwager S, et al. 2009a. B-cell count and survival: Differentiating chronic lymphocytic leukemia from monoclonal B-cell lymphocytosis based on clinical outcome. Blood 113: 4188-4196. doi:10.1182/blood-2008-09-176149

Shanafelt TD, Kay NE, Rabe KG, Call TG, Zent CS, Maddocks K, Jenkins G, Jelinek DF, Morice WG, Boysen J, et al. 2009b. Brief report: Natural history of individuals with clinically recognized monoclonal B-cell lymphocytosis compared with patients with Rai 0 chronic lymphocytic leukemia. J Clin Oncol 27: 3959-3963. doi:10.1200/JCO .2008 .21 .2704

Shanafelt TD, Ghia P, Lanasa MC, Landgren O, Rawstron AC. 2010. Monoclonal B-cell lymphocytosis (MBL): Biology, natural history and clinical management. Leukemia 24: 512-520. doi:10.1038/leu.2009.287

Simonsson B, Wibell L, Nilsson K. 1980. $\beta 2$-microglobulin in chronic lymphocytic leukaemia. Scand J Haematol 24: 174-180. doi:10.1111/j.1600-0609.1980.tb02364.x

Slager SL, Rabe KG, Achenbach SJ, Vachon CM, Goldin LR, Strom SS, Lanasa MC, Spector LG, Rassenti LZ, Leis JF, et al. 2011. Genome-wide association study identifies a novel susceptibility locus at 6p21.3 among familial CLL. Blood 117: 1911-1916. doi:10.1182/blood-2010-09308205

Slager SL, Skibola CF, Di Bernardo MC, Conde L, Broderick P, McDonnell SK, Goldin LR, Croft N, Holroyd A, Harris S, et al. 2012. Common variation at 6p21.31 (BAK1) influences the risk of chronic lymphocytic leukemia. Blood 120: 843-846. doi:10.1182/blood-2012-03-413591

Slupsky JR. 2014. Does B cell receptor signaling in chronic lymphocytic leukaemia cells differ from that in other B cell types? Scientifica (Cairo) 2014: 208928. doi:10.1155/ 2014/208928

Solomon BM, Chaffee KG, Moreira J, Schwager SM, Cerhan JR, Call TG, Kay NE, Slager SL, Shanafelt TD. 2016. Risk of non-hematologic cancer in individuals with highcount monoclonal B-cell lymphocytosis. Leukemia 30: 331-336. doi:10.1038/leu.2015.235

Sommermeyer D, Hudecek M, Kosasih PL, Gogishvili T, Maloney DG, Turtle CJ, Riddell SR. 2016. Chimeric antigen receptor-modified $\mathrm{T}$ cells derived from defined $\mathrm{CD} 8^{+}$and $\mathrm{CD} 4^{+}$subsets confer superior antitumor reac- tivity in vivo. Leukemia 30: 492-500. doi:10.1038/leu .2015 .247

Souers AJ, Leverson JD, Boghaert ER, Ackler SL, Catron ND, Chen J, Dayton BD, Ding H, Enschede SH, Fairbrother WJ, et al. 2013. ABT-199, a potent and selective BCL-2 inhibitor, achieves antitumor activity while sparing platelets. Nat Med 19: 202-208. doi:10.1038/nm.3048

Spaargaren M, Beuling EA, Rurup ML, Meijer HP, Klok MD, Middendorp S, Hendriks RW, Pals ST. 2003. The B cell antigen receptor controls integrin activity through Btk and PLC $\gamma 2$. J Exp Med 198: 1539-1550. doi:10.1084/ jem.20011866

Speedy HE, Bernardo MC, Sava GP, Dyer MJS, Holroyd A, Wang Y, Sunter NJ, Mansouri L, Juliusson G, Smedby KE, et al. 2014. A genome-wide association study identifies multiple susceptibility loci for chronic lymphocytic leukemia. Nat Genet 46: 56-60. doi:10.1038/ng.2843

Stamatopoulos K, Belessi C, Moreno C, Boudjograh M, Guida G, Smilevska T, Belhoul L, Stella S, Stavroyianni N, Crespo M, et al. 2007. Over $20 \%$ of patients with chronic lymphocytic leukemia carry stereotyped receptors: Pathogenetic implications and clinical correlations. Blood 109: 259-270. doi:10.1182/blood-2006-03-012948

Stamatopoulos K, Agathangelidis A, Rosenquist R, Ghia P. 2017. Antigen receptor stereotypy in chronic lymphocytic leukemia. Leukemia 31: 282-291. doi:10.1038/leu.2016 .322

Steininger C, Widhopf GF II, Ghia EM, Morello CS, Vanura K, Sanders R, Spector D, Guiney D, Jäger U, Kipps TJ. 2012. Recombinant antibodies encoded by IGHV1-69 react with pUL32, a phosphoprotein of cytomegalovirus and B-cell superantigen. Blood 119: 2293-2301. doi:10 .1182/blood-2011-08-374058

Sthoeger ZM, Wakai M, Tse DB, Vinciguerra VP, Allen SL, Budman DR, Lichtman SM, Schulman P, Weiselberg LR, Chiorazzi N. 1989. Production of autoantibodies by CD5expressing B lymphocytes from patients with chronic lymphocytic leukemia. J Exp Med 169: 255-268. doi:10 $.1084 /$ jem.169.1.255

Stilgenbauer S, Schnaiter A, Paschka P, Zenz T, Rossi M, Döhner K, Bühler A, Böttcher S, Ritgen M, Kneba M, et al. 2014. Gene mutations and treatment outcome in chronic lymphocytic leukemia: Results from the CLL8 trial. Blood 123: 3247-3254. doi:10.1182/blood-201401-546150

Strefford JC, Kadalayil L, Forster J, Mjj R-Z, Parker A, Lin TT, Heppel N, Norris K, Gardiner A, Davies Z, et al. 2015 Telomere length predicts progression and overall survival in chronic lymphocytic leukemia: Data from the UK LRF CLL4 trial. Leukemia 29: 2411-2414. doi:10.1038/leu .2015 .217

Sutton LA, Young E, Baliakas P, Hadzidimitriou A, Moysiadis T, Plevova K, Rossi D, Kminkova J, Stalika E, Pedersen LB, et al. 2016. Different spectra of recurrent gene mutations in subsets of chronic lymphocytic leukemia harboring stereotyped B-cell receptors. Haematologica 101: 959-967. doi:10.3324/haematol.2016.141812

Swerdlow SH, Murray LJ, Habeshaw JA, Stansfeld AG. 1984. Lymphocytic lymphoma/B-chronic lymphocytic leukaemia-An immunohistopathological study of peripheral B lymphocyte neoplasia. Br J Cancer 50: 587-599. doi:10 $.1038 /$ bjc. 1984.225 
N. Chiorazzi et al.

Tam CS, O'Brien S, Wierda W, Kantarjian H, Wen S, Do KA Thomas DA, Cortes J, Lerner S, Keating MJ. 2008. Longterm results of the fludarabine, cyclophosphamide, and rituximab regimen as initial therapy of chronic lymphocytic leukemia. Blood 112: 975-980. doi:10.1182/blood2008-02-140582

Tan SH, Sapari NS, Miao H, Hartman M, Loh M, Chng WJ Iau P, Buhari SA, Soong R, Lee SC. 2015. High-throughput mutation profiling changes before and 3 weeks after chemotherapy in newly diagnosed breast cancer patients. PLoS One 10: e0142466. doi:10.1371/journal.pone .0142466

Thompson JA, Figlin RA, Sifri-Steele C, Berenson RJ, Frohlich MW. 2003. A phase I trial of CD3/CD28-activated T cells (Xcellerated T cells) and interleukin-2 in patients with metastatic renal cell carcinoma. Clin Cancer Res 9 3562-3570.

Thompson PA, Tam CS, O'Brien SM, Wierda WG, Stingo F, Plunkett W, Smith SC, Kantarjian HM, Freireich EJ, Keating MJ. 2016. Fludarabine, cyclophosphamide, and rituximab treatment achieves long-term disease-free survival in IGHV-mutated chronic lymphocytic leukemia. Blood 127: 303-309. doi:10.1182/blood-2015-09-667675

Tobin G, Thunberg U, Johnson A, Eriksson I, Söderberg O, Karlsson K, Merup M, Juliusson G, Vilpo J, Enblad G, et al. 2003. Chronic lymphocytic leukemias utilizing the VH3-21 gene display highly restricted V $22-14$ gene use and homologous CDR3s: Implicating recognition of a common antigen epitope. Blood 101: 4952-4957. doi:10 .1182/blood-2002-11-3485

Tobin G, Thunberg U, Karlsson K, Murray F, Laurell A, Willander K, Enblad G, Merup M, Vilpo J, Juliusson G et al. 2004. Subsets with restricted immunoglobulin gene rearrangement features indicate a role for antigen selection in the development of chronic lymphocytic leukemia. Blood 104: 2879-2885. doi:10.1182/blood-2004-010132

Trimarco V, Ave E, Facco M, Chiodin G, Frezzato F, Martin V, Gattazzo C, Lessi F, Giorgi CA, Visentin A, et al. 2015 Cross-talk between chronic lymphocytic leukemia (CLL) tumor B cells and mesenchymal stromal cells (MSCs): Implications for neoplastic cell survival. Oncotarget 6: 42130-42149. doi:10.18632/oncotarget.6239

Tsai H-T, Caporaso NE, Kyle RA, Katzmann JA, Dispenzieri A, Hayes RB, Marti GE, Albitar M, Ghia P, Rajkumar SV, et al. 2009. Evidence of serum immunoglobulin abnormalities up to 9.8 years before diagnosis of chronic lymphocytic leukemia: A prospective study. Blood 114: 49284932. doi:10.1182/blood-2009-08-237651

Tsukada N, Burger JA, Zvaifler NJ, Kipps TJ. 2002. Distinctive features of "nurselike" cells that differentiate in the context of chronic lymphocytic leukemia. Blood 99: 1030-1037. doi:10.1182/blood.V99.3.1030

Turtle CJ, Hanafi L-A, Berger C, Hudecek M, Pender B, Robinson E, Hawkins R, Chaney C, Cherian S, Chen X, et al. 2016. Immunotherapy of non-Hodgkin's lymphoma with a defined ratio of $\mathrm{CD}^{+}$and $\mathrm{CD} 4^{+} \mathrm{CD} 19$-specific chimeric antigen receptor-modified T cells. Sci Transl Med 8: 355ra116. doi:10.1126/scitranslmed.aaf8621

Turtle CJ, Hay KA, Hanafi LA, Li D, Cherian S, Chen X, Wood B, Lozanski A, Byrd JC, Heimfeld S, et al. 2017. Durable molecular remissions in chronic lymphocytic leukemia treated with CD19-specific chimeric antigen receptor-modified T cells after failure of ibrutinib. J Clin Oncol 35: 3010-3020. doi:10.1200/JCO.2017.72.8519

Vaisitti T, Aydin S, Rossi D, Cottino F, Bergui L, D’Arena G, Bonello L, Horenstein AL, Brennan P, Pepper C, et al. 2010. CD38 increases CXCL12-mediated signals and homing of chronic lymphocytic leukemia cells. Leukemia 24: 958-969. doi:10.1038/leu.2010.36

van Dongen JJM, Langerak AW, Bruggemann M, Evans PAS, Hummel M, Lavender FL, Delabesse E, Davi F, Schuuring E, Garcia-Sanz R, et al. 2003. Design and standardization of PCR primers and protocols for detection of clonal immunoglobulin and T-cell receptor gene recombinations in suspect lymphoproliferations: Report of the BIOMED-2 Concerted Action BMH4CT98-3936. Leukemia 17: 2257-2317. doi:10.1038/sj .leu.2403202

van Gent R, Kater AP, Otto SA, Jaspers A, Borghans JA, Vrisekoop N, Ackermans MA, Ruiter AF, Wittebol S, Eldering E, et al. 2008. In vivo dynamics of stable chronic lymphocytic leukemia inversely correlate with somatic hypermutation levels and suggest no major leukemic turnover in bone marrow. Cancer Res 68: 10137-10144. doi:10.1158/0008-5472.CAN-08-2325

Van Roosbroeck K, Bayraktar R, Calin S, Bloehdorn J, Dragomir MP, Okubo K, Bertilaccio MTS, Zupo S, You MJ, Gaidano G, et al. 2018. miRNAs involvement in the pathogenesis of Richter's syndrome. Haematologica 104: 1004-1015.

Vardi A, Agathangelidis A, Sutton LA, Ghia P, Rosenquist R, Stamatopoulos K. 2014. Immunogenetic studies of chronic lymphocytic leukemia: Revelations and speculations about ontogeny and clinical evolution. Cancer Res 74: 4211-4216. doi:10.1158/0008-5472.CAN-14-0630

Varghese AM, Howard DR, Pocock C, Rawstron AC, Follows G, McCarthy H, Dearden C, Fegan C, Milligan D, Smith AF, et al. 2017. Eradication of minimal residual disease improves overall and progression-free survival in patients with chronic lymphocytic leukaemia, evidence from NCRN CLL207: A phase II trial assessing alemtuzumab consolidation. Br J Haematol 176: 573-582. doi:10.1111/ bjh. 14342

Villamor N, Conde L, Martinez-Trillos A, Cazorla M, Navarro A, Bea S, Lopez C, Colomer D, Pinyol M, Aymerich $\mathrm{M}$, et al. 2013. NOTCH1 mutations identify a genetic subgroup of chronic lymphocytic leukemia patients with high risk of transformation and poor outcome. Leukemia 27: 1100-1106. doi:10.1038/leu.2012.357

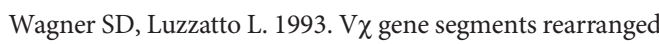
in chronic lymphocytic leukemia are distributed over a large portion of the $\mathrm{V} \chi$ locus and do not show somatic mutation. Eur J Immunol 23: 391-397. doi:10.1002/eji .1830230214

Wang L, Lawrence MS, Wan Y, Stojanov P, Sougnez C, Stevenson K, Werner L, Sivachenko A, DeLuca DS, Zhang L, et al. 2011. SF3B1 and other novel cancer genes in chronic lymphocytic leukemia. N Engl J Med 365: 2497-2506. doi:10.1056/NEJMoa1109016

Wang J, Khiabanian H, Rossi D, Fabbri G, Gattei V, Forconi F, Laurenti L, Marasca R, Del Poeta G, Foa R, et al. 2014 Tumor evolutionary directed graphs and the history of 
chronic lymphocytic leukemia. Elife 3: e02869. doi:10 .7554/eLife.02869

Went M, Sud A, Speedy H, Sunter NJ, Försti A, Law PJ, Johnson DC, Mirabella F, Holroyd A, Li N, et al. 2019. Genetic correlation between multiple myeloma and chronic lymphocytic leukaemia provides evidence for shared aetiology. Blood Cancer J 9: 1. doi:10.1038/ s41408-018-0162-8

Widhopf GF II, Kipps TJ. 2001. Normal B cells express 51p1encoded Ig heavy chains that are distinct from those expressed by chronic lymphocytic leukemia B cells. J Immunol 166: 95-102. doi:10.4049/jimmunol.166.1.95

Wierda WG, O’Brien S, Wang X, Faderl S, Ferrajoli A, Do KA, Cortes J, Thomas D, Garcia-Manero G, Koller C, et al. 2007. Prognostic nomogram and index for overall survival in previously untreated patients with chronic lymphocytic leukemia. Blood 109: 4679-4685. doi:10.1182/ blood-2005-12-051458

Wierda WG, O'Brien S, Wang X, Faderl S, Ferrajoli A, Do KA, Garcia-Manero G, Cortes J, Thomas D, Koller CA, et al. 2011. Multivariable model for time to first treatment in patients with chronic lymphocytic leukemia. J Clinl Oncol 29: 4088-4095. doi:10.1200/JCO.2010.33.9002

Wiseman H, Halliwell B. 1996. Damage to DNA by reactive oxygen and nitrogen species: Role in inflammatory disease and progression to cancer. Biochem J 313: 17-29. doi:10.1042/bj3130017

Woyach JA, Furman RR, Liu T-M, Ozer HG, Zapatka M, Ruppert AS, Xue L, Li DH-H, Steggerda SM, Versele M, et al. 2014a. Resistance mechanisms for the Bruton's tyrosine kinase inhibitor ibrutinib. New Engl J Med 370: 2286-2294. doi:10.1056/NEJMoa1400029

Woyach JA, Smucker K, Smith LL, Lozanski A, Zhong Y, Ruppert AS, Lucas D, Williams K, Zhao W, Rassenti L, et al. 2014b. Prolonged lymphocytosis during ibrutinib therapy is associated with distinct molecular characteristics and does not indicate a suboptimal response to therapy. Blood 123: 1810-1817. doi:10.1182/blood-2013-09527853

Yamane A, Resch W, Kuo N, Kuchen S, Li Z, Sun HW, Robbiani DF, McBride K, Nussenzweig MC, Casellas R. 2011. Deep-sequencing identification of the genomic targets of the cytidine deaminase AID and its cofactor RPA in B lymphocytes. Nat Immunol 12: 62-69. doi:10.1038 ni. 1964

Yamauchi T, Nowak BJ, Keating MJ, Plunkett W. 2001. DNA repair initiated in chronic lymphocytic leukemia lymphocytes by 4-hydroperoxycyclophosphamide is inhibited by fludarabine and clofarabine. Clin Cancer Res 7: 35803589.

Yang J, Baskar S, Kwong KY, Kennedy MG, Wiestner A, Rader C. 2011. Therapeutic potential and challenges of targeting receptor tyrosine kinase ROR1 with monoclonal antibodies in B-cell malignancies. PLoS One 6: e21018. doi:10.1371/journal.pone.0021018

Yu J, Chen L, Cui B, Widhopf GF II, Shen Z, Wu R, Zhang L, Zhang S, Briggs SP, Kipps TJ. 2016. Wnt5a induces ROR1/ROR2 heterooligomerization to enhance leukemia chemotaxis and proliferation. J Clin Invest 126: 585-598. doi:10.1172/JCI83535

Yu J, Chen L, Chen Y, Hasan K, Ghia EM, Zhang L, Wu R, Rassenti LZ, Widhopf GF, Shen Z, et al. 2017. Wnt5a induces ROR1 to associate with $14-3-3 \zeta$ for enhanced chemotaxis and proliferation of chronic lymphocytic leukemia cells. Leukemia 31: 2608-2614. doi:10.1038/leu .2017 .132

Zablotska LB, Bazyka D, Lubin JH, Gudzenko N, Little MP, Hatch M, Finch S, Dyagil I, Reiss RF, Chumak VV, et al. 2013. Radiation and the risk of chronic lymphocytic and other leukemias among Chornobyl cleanup workers. Environ Health Perspect 121: 59-65. doi:10.1289/ehp .1204996

Zenz T, Eichhorst B, Busch R, Denzel T, Habe S, Winkler D, Buhler A, Edelmann J, Bergmann M, Hopfinger G, et al. 2010a. TP53 Mutation and survival in chronic lymphocytic leukemia. J Clin Oncol 8: 4473-4479. doi:10.1200/ JCO.2009.2027.8762

Zenz T, Fröhling S, Mertens D, Döhner H, Stilgenbauer S. 2010b. Moving from prognostic to predictive factors in chronic lymphocytic leukaemia (CLL). Best Pract Res Clin Haematol 23: 71-84. doi:10.1016/j.beha.2009.12.003

Zhou Y, Hileman EO, Plunkett W, Keating MJ, Huang P. 2003. Free radical stress in chronic lymphocytic leukemia cells and its role in cellular sensitivity to ROS-generating anticancer agents. Blood 101: 4098-4104. doi:10.1182/ blood-2002-08-2512

Zhou Y, Tang G, Medeiros LJ, McDonnell TJ, Keating MJ, Wierda WG, Wang SA. 2012. Therapy-related myeloid neoplasms following fludarabine, cyclophosphamide, and rituximab (FCR) treatment in patients with chronic lymphocytic leukemia/small lymphocytic lymphoma. Mod Pathol 25: 237-245. doi:10.1038/modpathol.2011.158

Zucchetto A, Benedetti D, Tripodo C, Bomben R, Dal Bo M, Marconi D, Bossi F, Lorenzon D, Degan M, Rossi FM, et al. 2009. CD38/CD31, the CCL3 and CCL4 chemokines, and CD49d/vascular cell adhesion molecule-1 are interchained by sequential events sustaining chronic lymphocytic leukemia cell survival. Cancer Res 69: 4001-4009. doi:10.1158/0008-5472.CAN-08-4173

Zucchetto A, Vaisitti T, Benedetti D, Tissino E, Bertagnolo V, Rossi D, Bomben R, Dal Bo M, Del Principe MI, Gorgone A, et al. 2012. The CD49d/CD29 complex is physically and functionally associated with CD38 in B-cell chronic lymphocytic leukemia cells. Leukemia 26: 1301-1312. doi:10.1038/leu.2011.369 


\section{$\&_{\mathrm{CSH}}^{\infty} \&$ Cold Spring Harbor

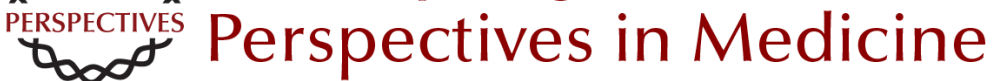

\section{Chronic Lymphocytic Leukemia}

Nicholas Chiorazzi, Shih-Shih Chen and Kanti R. Rai

Cold Spring Harb Perspect Med 2021; doi: 10.1101/cshperspect.a035220 originally published online March 30, 2020

\section{Subject Collection Leukemia and Lymphoma: Molecular and Therapeutic Insights}

Oncogenic Mechanisms and Therapeutic Targeting of Metabolism in Leukemia and Lymphoma

Maximilian Stahl, Zachary D. Epstein-Peterson and Andrew M. Intlekofer

Non-Hodgkin Lymphomas: Malignancies Arising from Mature B Cells Jennifer Shingleton, Jie Wang, Carolyn Baloh, et al.

MAP-Kinase-Driven Hematopoietic Neoplasms: A Decade of Progress in the Molecular Age Rikhia Chakraborty, Omar Abdel-Wahab and Benjamin H. Durham

Mouse Models in the Study of Mature B-Cell Malignancies Laura Pasqualucci and Ulf Klein

Mouse Models of Myeloid Malignancies Faisal Basheer and George Vassiliou

Epigenetic Mechanisms in Leukemias and Lymphomas

Cihangir Duy, Wendy Béguelin and Ari Melnick

The Biology of B-Progenitor Acute Lymphoblastic Leukemia

Kathryn G. Roberts and Charles G. Mullighan

RNA Regulators in Leukemia and Lymphoma Camila Prieto and Michael G. Kharas
Biological and Translational Considerations regarding the Recent Therapeutic Successes and Upcoming Challenges for Multiple Myeloma Constantine S. Mitsiades

Biology and Molecular Pathogenesis of Mature T-Cell Lymphomas José R. Cortés and Teresa Palomero

The Role of Somatic Mutations in Acute Myeloid Leukemia Pathogenesis Ashwin Kishtagari and Ross L. Levine

Chronic Lymphocytic Leukemia Nicholas Chiorazzi, Shih-Shih Chen and Kanti R. Rai

Normal Hematopoiesis Is a Balancing Act of

Self-Renewal and Regeneration Oakley C. Olson, Yoon-A Kang and Emmanuelle Passegué

Impact of Genetics on Mature Lymphoid

Leukemias and Lymphomas

Nathanael G. Bailey and Kojo S.J. Elenitoba-Johnson

Epidemiology and Etiology of Leukemia and

Lymphoma Jordan A. Baeker Bispo, Paulo S. Pinheiro and Erin K. Kobetz

Clonal Hematopoiesis and Premalignant Diseases Justin Kaner, Pinkal Desai, Nuria Mencia-Trinchant, et al.

For additional articles in this collection, see http://perspectivesinmedicine.cshlp.org/cgi/collection/ 